\title{
Neuroactive Type-A $\gamma$-Aminobutyric Acid Receptor Allosteric Modulator Steroids from the Hypobranchial Gland of Marine Mollusk, Conus geographus
}

Changshan $\mathrm{Niu}^{\dagger}$, Lee S. Leavitt ${ }^{\ddagger}$, Zhenjian Lin ${ }^{\dagger}$, Noemi D. Paguigan ${ }^{\dagger}$, Lili Sun ${ }^{\S}$, Jie Zhang॥, Joshua P. Torres ${ }^{\dagger}$, Shrinivasan Raghuraman ${ }^{\ddagger}$ Kevin Chase ${ }^{\star}$, Roberto Cadeddu ${ }^{\S}$, Manju Karthikeyan ${ }^{\ddagger}$, Marco Bortolato ${ }^{\S}$, Christopher A. Reilly ${ }^{\S}$, Ronald W. Hughen", Alan R. Light", Baldomero M. Olivera ${ }^{\ddagger}$ Eric W. Schmidt ${ }^{*} \dagger$

†Department of Medicinal Chemistry, University of Utah, Salt Lake City, Utah 84112, United States

${ }^{\star}$ School of Biological Sciences, University of Utah, Salt Lake City, Utah 84112, United States

${ }^{\S}$ Department of Pharmacology and Toxicology, University of Utah, Salt Lake City, Utah 84112, United States

"Department of Anesthesiology, School of Medicine, University of Utah, Salt Lake City, Utah 84112, United States

\section{Table of Contents}

\begin{tabular}{|c|c|c|}
\hline Figure S1. & (+)-HRESIMS of $\mathbf{1}$ & S3 \\
\hline Figure S2. & IR spectrum of $\mathbf{1}$. & S3 \\
\hline Figure S3. & ${ }^{1} \mathrm{H}-\mathrm{NMR}(600 \mathrm{MHz})$ spectrum of $\mathbf{1}$ in methanol- $d_{4}$. & S4 \\
\hline Figure S4. & ${ }^{13} \mathrm{C}-\mathrm{NMR}(125 \mathrm{MHz})$ spectrum of $\mathbf{1}$ in methanol- $d_{4}$ & $\mathrm{~S} 4$ \\
\hline Figure S5. & ${ }^{1} \mathrm{H}-{ }^{1} \mathrm{H}$ COSY $(600 \mathrm{MHz})$ spectrum of $\mathbf{1}$ in methanol- $d 4$. & S5 \\
\hline Figure S6. & TOCSY $(600 \mathrm{MHz})$ spectrum of $\mathbf{1}$ in methanol- $d 4$. & S5 \\
\hline Figure S7. & HSQC (600MHz) spectrum of $\mathbf{1}$ in methanol- $d 4$. & S6 \\
\hline Figure S8. & HMBC (600MHz) spectrum of $\mathbf{1}$ in methanol- $d 4$. & S6 \\
\hline Figure S9. & NOESY $(600 \mathrm{MHz})$ spectrum of $\mathbf{1}$ in methanol- $d 4$. & S7 \\
\hline Figure S10. & (+)-HRESIMS of 2. & S7 \\
\hline Figure S11. & IR spectrum of 2. & S8 \\
\hline Figure S12. & ${ }^{1} \mathrm{H}-\mathrm{NMR}(600 \mathrm{MHz})$ spectrum of 2 in methanol- $d_{4}$ & S8 \\
\hline Figure S13. & ${ }^{1} \mathrm{H}-{ }^{1} \mathrm{H}$ COSY $(600 \mathrm{MHz})$ spectrum of 2 in methanol- $d 4$. & S9 \\
\hline Figure S14. & HSQC (600MHz) spectrum of $\mathbf{2}$ in methanol- $d 4$. & S9 \\
\hline Figure S15. & HMBC (600MHz) spectrum of $\mathbf{2}$ in methanol- $d 4$. & $\mathrm{S} 10$ \\
\hline Figure S16. & NOESY (600MHz) spectrum of 2 in methanol- $d 4$. & $\mathrm{S} 10$ \\
\hline Figure S17. & (+)-HRESIMS of $\mathbf{3}$. & S11 \\
\hline Figure S18. & IR spectrum of $\mathbf{3}$. & S11 \\
\hline Figure S19. & ${ }^{1} \mathrm{H}-\mathrm{NMR}(600 \mathrm{MHz})$ spectrum of $\mathbf{3}$ in methanol- $d_{4}$. & S12 \\
\hline Figure S20. & ${ }^{1} \mathrm{H}-{ }^{1} \mathrm{H}$ COSY $(600 \mathrm{MHz})$ spectrum of $\mathbf{3}$ in methanol- $d 4$. & $\mathrm{S} 12$ \\
\hline Figure S21. & HSQC (600MHz) spectrum of $\mathbf{3}$ in methanol- $d 4$. & S13 \\
\hline Figure S22. & HMBC (600MHz) spectrum of $\mathbf{3}$ in methanol- $d 4$. & S13 \\
\hline Figure S23. & NOESY (600MHz) spectrum of 3 in methanol- $d 4$. & S14 \\
\hline Figure S24. & (+)-HRESIMS of 4. & S14 \\
\hline Figure S25. & IR spectrum of 4. & S15 \\
\hline Figure S26. & ${ }^{1} \mathrm{H}-\mathrm{NMR}(600 \mathrm{MHz})$ spectrum of $\mathbf{4}$ in methanol- $d_{4}$. & S15 \\
\hline
\end{tabular}




\begin{tabular}{|c|c|c|}
\hline Figure S27. & ${ }^{1} \mathrm{H}-{ }^{1} \mathrm{H}$ COSY $(600 \mathrm{MHz})$ spectrum of $\mathbf{4}$ in methanol- $d 4$. & $\mathrm{S} 16$ \\
\hline Figure S28. & TOCSY $(600 \mathrm{MHz})$ spectrum of $\mathbf{4}$ in methanol- $d 4$. & $\mathrm{S} 16$ \\
\hline Figure S29. & HSQC (600MHz) spectrum of $\mathbf{4}$ in methanol- $d 4$. & $\mathrm{S} 17$ \\
\hline Figure S30. & HMBC $(600 \mathrm{MHz})$ spectrum of 4 in methanol- $d 4$. & $\mathrm{S} 17$ \\
\hline Figure S31. & NOESY $(600 \mathrm{MHz})$ spectrum of $\mathbf{4}$ in methanol- $d 4$. & $\mathrm{S} 18$ \\
\hline Figure S32. & (+)-HRESIMS of 5. & $\mathrm{~S} 18$ \\
\hline Figure S33. & IR spectrum of $\mathbf{5}$. & $\mathrm{S} 19$ \\
\hline Figure S34. & ${ }^{1} \mathrm{H}-\mathrm{NMR}(600 \mathrm{MHz})$ spectrum of $\mathbf{5}$ in methanol- $d_{4}$. & $\mathrm{S} 19$ \\
\hline Figure S35. & ${ }^{13} \mathrm{C}-\mathrm{NMR}(125 \mathrm{MHz})$ spectrum of 5 in methanol- $d_{4}$ & $\mathrm{~S} 20$ \\
\hline Figure S36. & ${ }^{1} \mathrm{H}-{ }^{1} \mathrm{H}$ COSY $(600 \mathrm{MHz})$ spectrum of 5 in methanol- $d 4$. & $\mathrm{S} 20$ \\
\hline Figure S37. & HSQC (600MHz) spectrum of $\mathbf{5}$ in methanol- $d 4$. & $\mathrm{S} 21$ \\
\hline Figure S38. & HMBC (600MHz) spectrum of 5 in methanol- $d 4$. & $\mathrm{S} 21$ \\
\hline Figure S39. & NOESY $(600 \mathrm{MHz})$ spectrum of 5 in methanol- $d 4$. & $\mathrm{S} 22$ \\
\hline Figure S40. & Key COSY, HMBC, and NOESY correlations for compounds 2,4 and 5. & S22 \\
\hline Figure S41. & UV spectra of 1-5. & S23 \\
\hline Figure S42. & (+)-HRESIMS of 6. & $\mathrm{~S} 23$ \\
\hline Figure S43. & Purity of compound 6 by HPLC. & $\mathrm{S} 24$ \\
\hline Figure S44. & ${ }^{1} \mathrm{H}-\mathrm{NMR}(500 \mathrm{MHz})$ spectrum of 6 in methanol- $d_{4}$. & $\mathrm{S} 24$ \\
\hline Figure S45. & ${ }^{13} \mathrm{C}-\mathrm{NMR}(125 \mathrm{MHz})$ spectrum of 6 in methanol- $d_{4}$. & S25 \\
\hline Figure S46. & Calcium free DRG experiment of compound $\mathbf{6}$. & $\mathrm{S} 25$ \\
\hline Figure S47. & DRG activity of $6(10 \mu \mathrm{M})$ with or without detergent Pluronic F127 $(0.02 \%)$. & S26 \\
\hline Figure S48. & Dose response of $6(0.5,1,10,20$ and $40 \mu \mathrm{M})$ to $\mathrm{KCl}(30 \mathrm{mM})$ in DRG assay. & S26 \\
\hline Figure S49. & Single cell transcriptomic $\mathrm{GABA}_{\mathrm{A}}$ receptor gene experission in mouse specific DRG cells. & $\mathrm{S} 27$ \\
\hline Figure S50. & Constellation pharmacology of $6(0.5 \mu \mathrm{M})$ in presence of GABA $(340 \mu \mathrm{M})$. & $\mathrm{S} 28$ \\
\hline Figure S51. & Effects of $6(2,10,50 \mathrm{mg} / \mathrm{kg}$, I.P.) on Elevated Plus Maze (EPM) model. & S29 \\
\hline Figure S52. & Effects of $\mathbf{6}(2,10,50 \mathrm{mg} / \mathrm{kg}$, I.P. $)$ on Open Field (OF) test. & $\mathrm{S} 30$ \\
\hline Figure S53. & 5-HT1A receptor binding assay of compound $\mathbf{6}$. & S31 \\
\hline Figure S54. & Cytotoxicity of the crude extract of hypobranchial gland of C. geographus in HEK 293 cell line. & S31 \\
\hline Figure S55. & Selected $\mathrm{GABA}_{A} \mathrm{R}(\alpha 1 \beta 3 \gamma 2)$ responses to $\mathrm{GABA} \mathrm{EC}_{20}$ in the absence and presence of $\mathbf{6}$. & $\mathrm{S} 32$ \\
\hline Table S1. & NMR data of compounds $\mathbf{1}-\mathbf{5}(\delta$ in ppm, $J$ in $\mathrm{Hz})$ in methanol- $d 4$. & $\mathrm{S} 33$ \\
\hline Table S2. & Summary electrophysiology data of compound $\mathbf{6}$ on selected human $\mathrm{GABA}_{\mathrm{A}} \mathrm{R}$ subtypes. & S34 \\
\hline
\end{tabular}




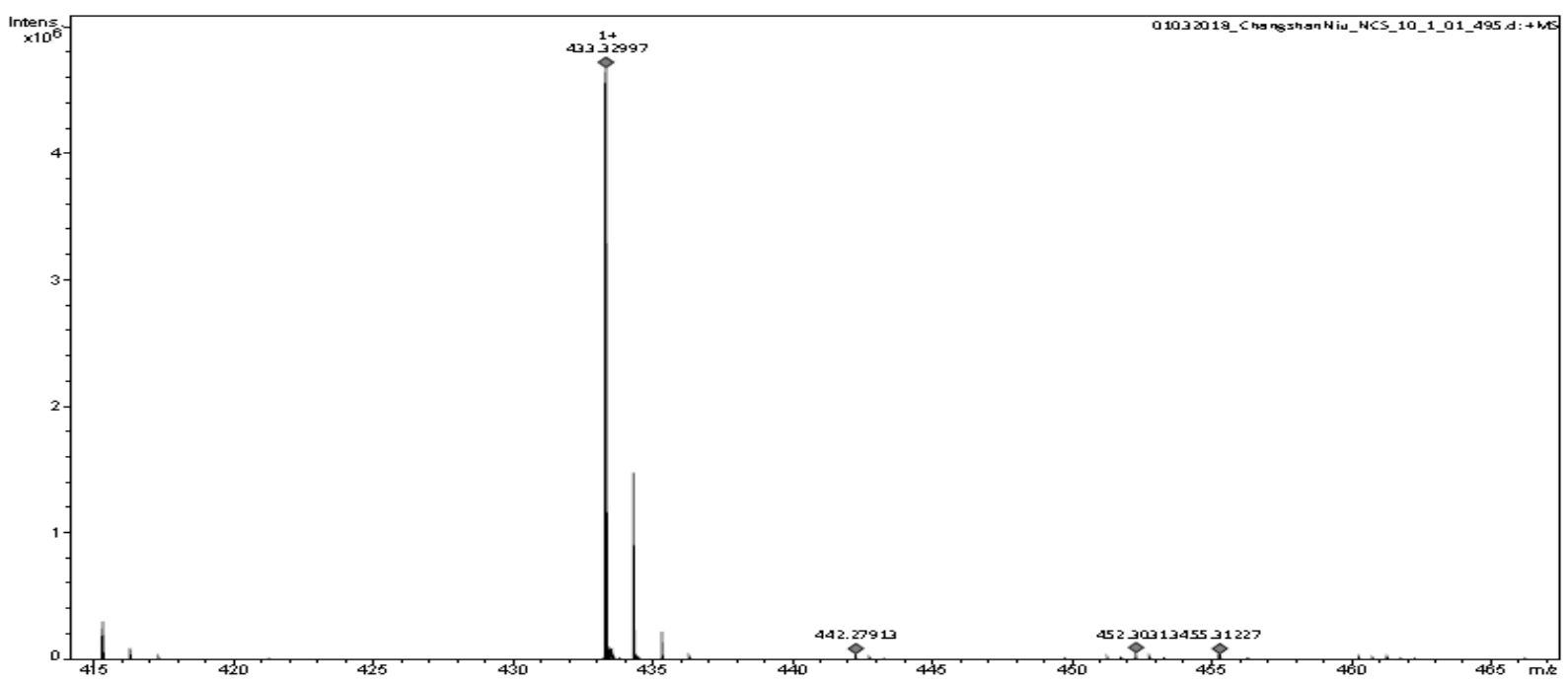

Figure S1. (+)-HRESIMS of 1

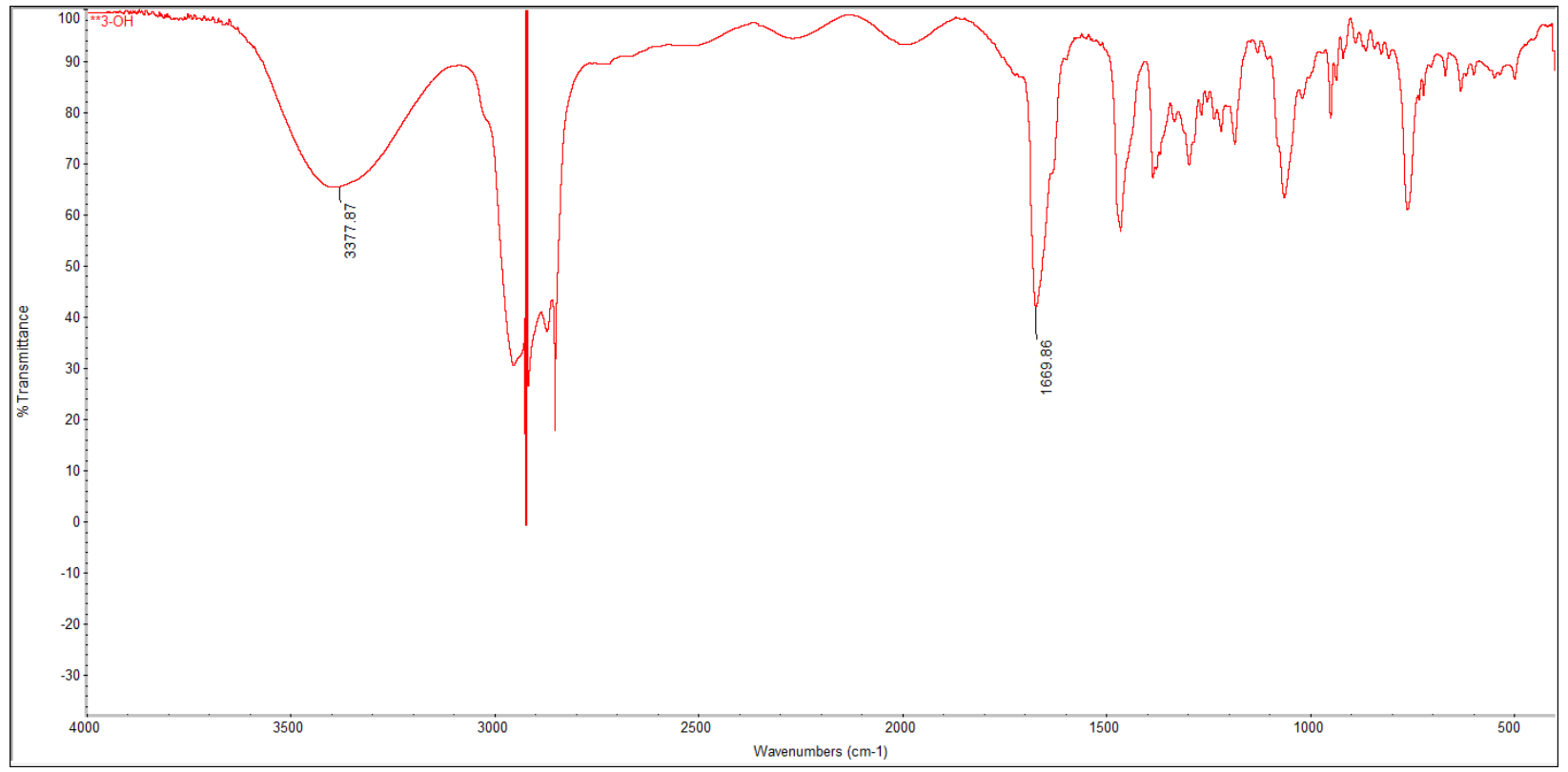

Figure S2. IR spectrum of $\mathbf{1}$. 


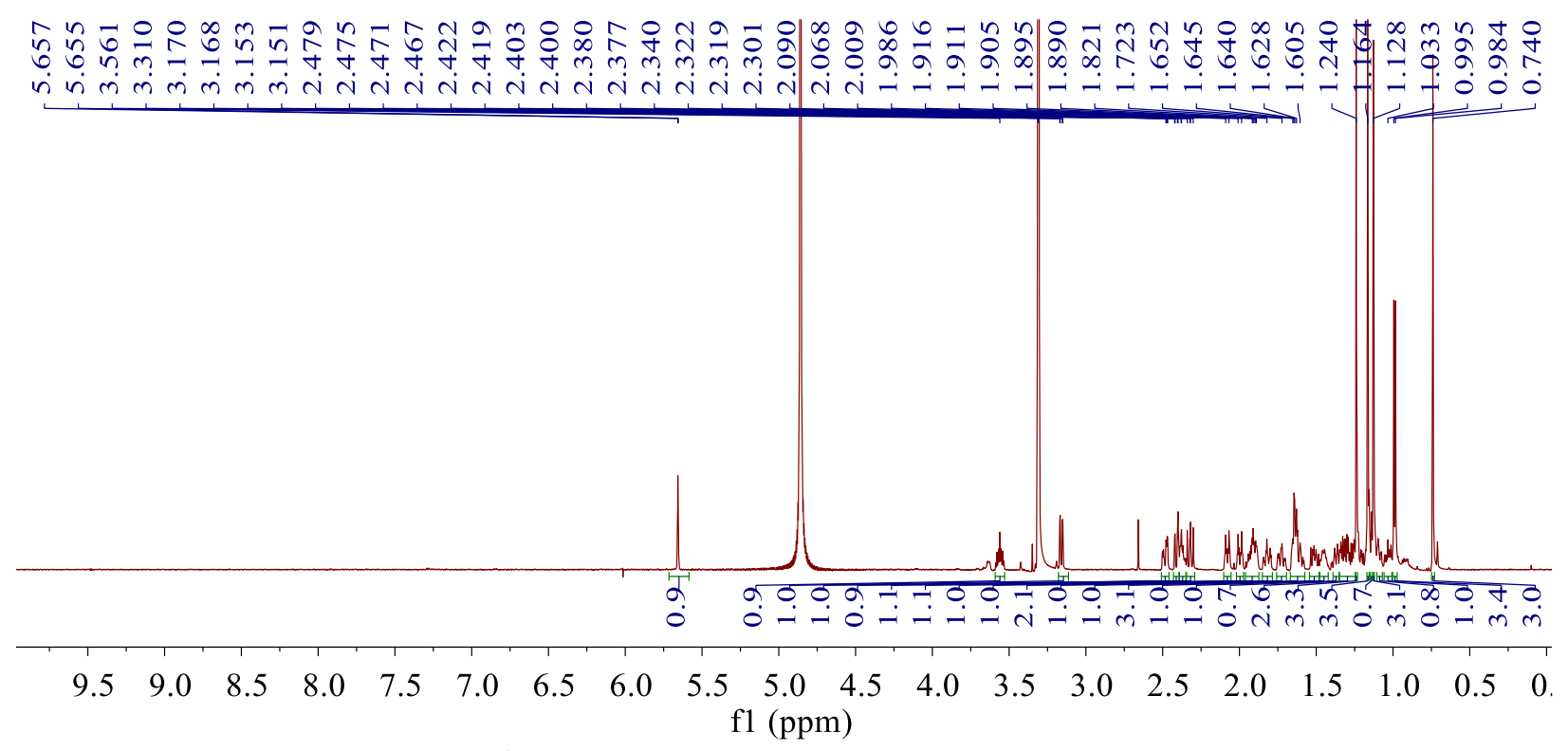

Figure S3. ${ }^{1} \mathrm{H}-\mathrm{NMR}(600 \mathrm{MHz})$ spectrum of $\mathbf{1}$ in methanol- $d_{4}$.

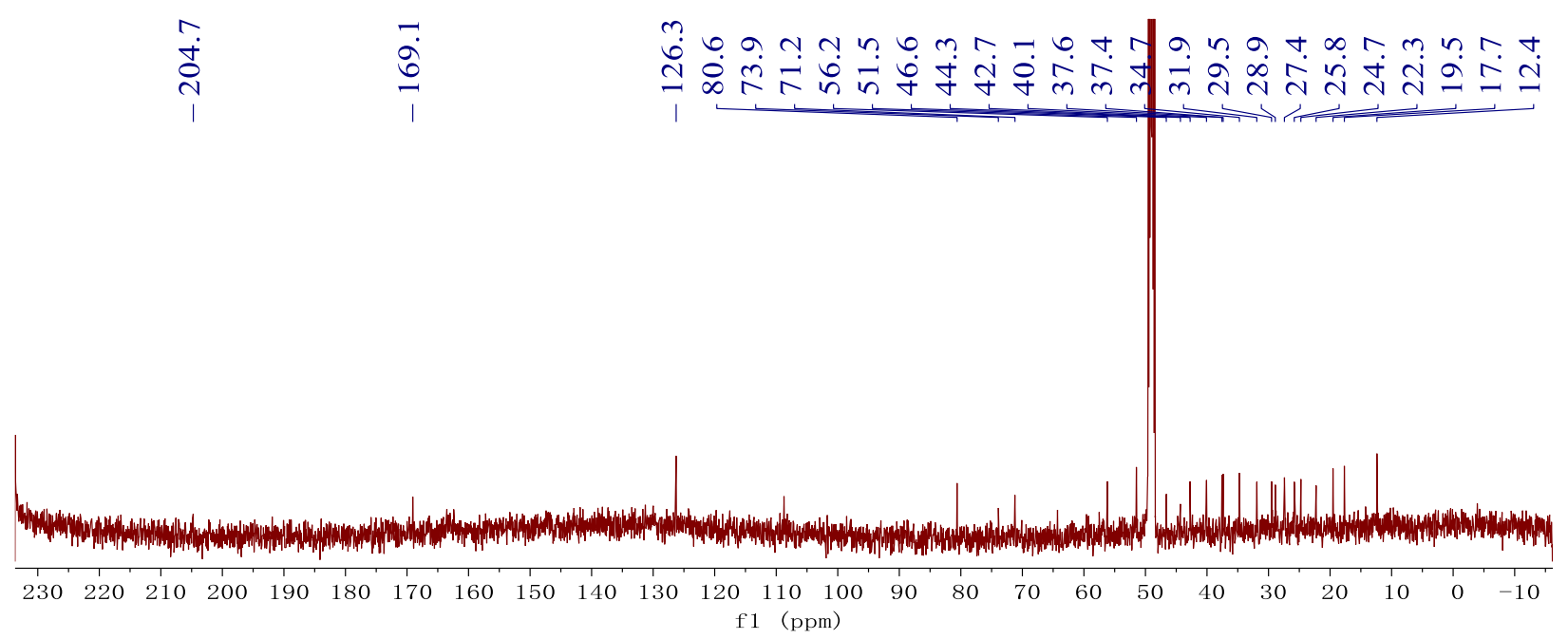

Figure S4. ${ }^{13} \mathrm{C}-\mathrm{NMR}(125 \mathrm{MHz})$ spectrum of $\mathbf{1}$ in methanol- $d_{4}$. 


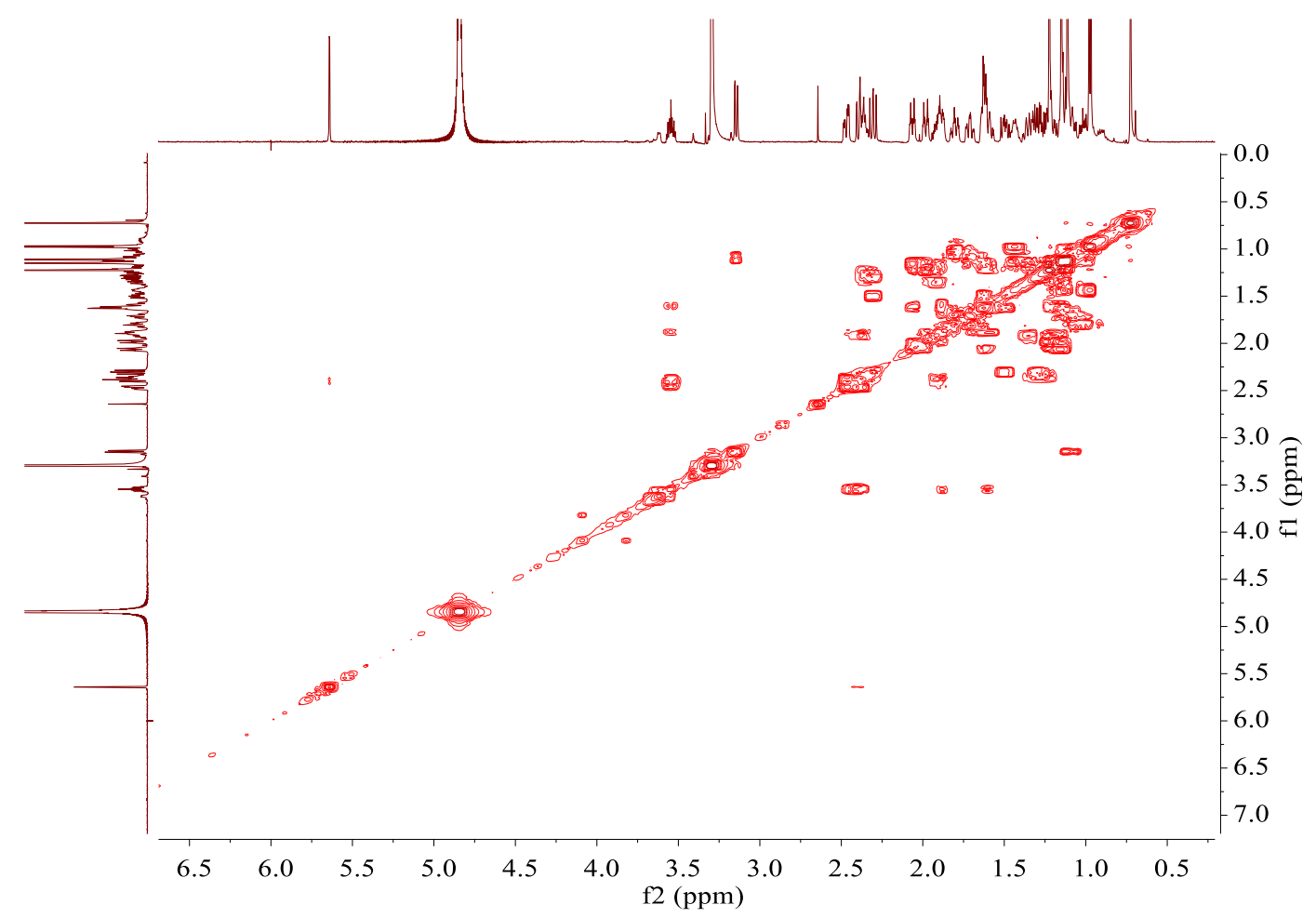

Figure S5. ${ }^{1} \mathrm{H}-{ }^{1} \mathrm{H}$ COSY $(600 \mathrm{MHz})$ spectrum of 1 in methanol- $d_{4}$.

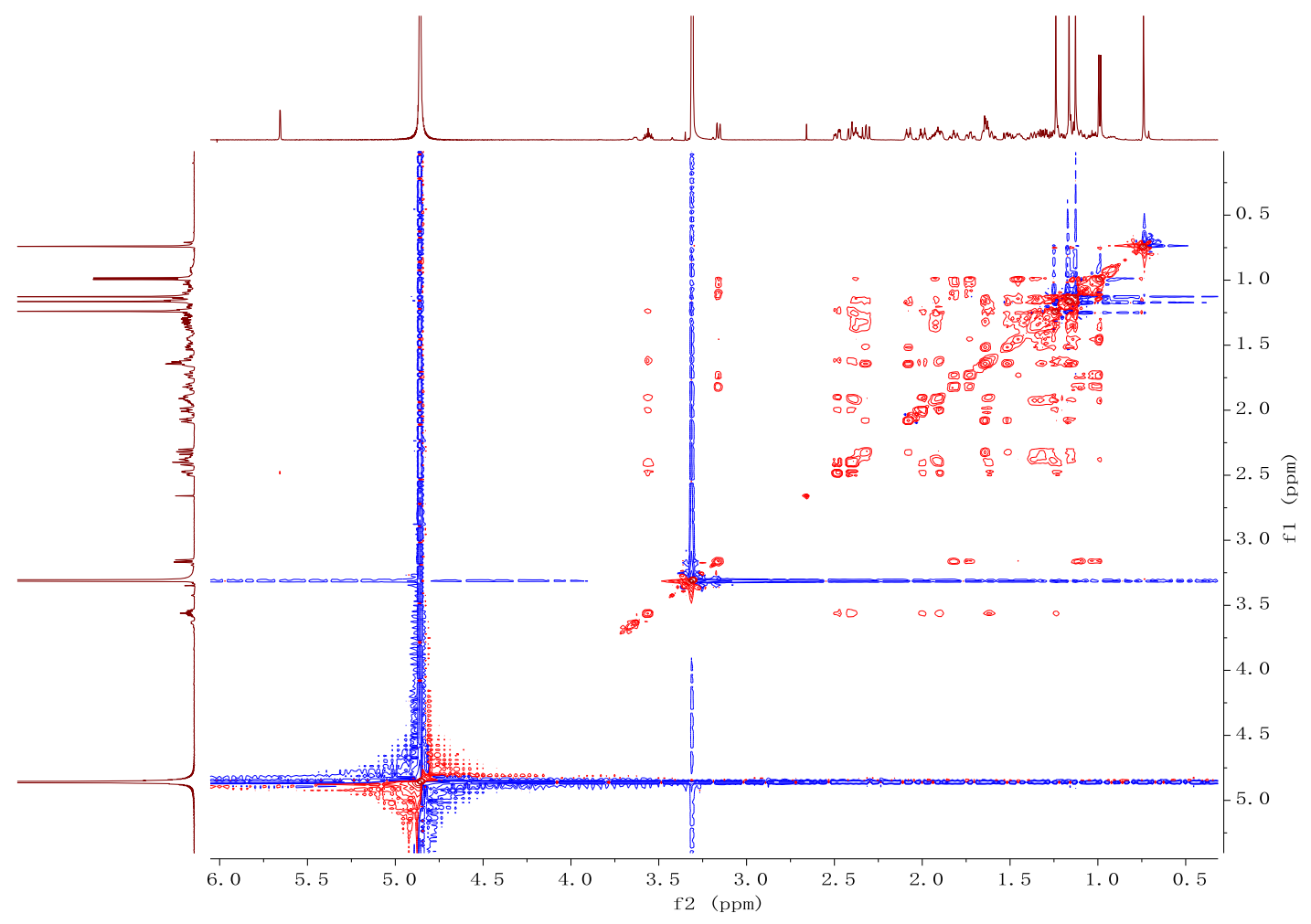

Figure S6. TOCSY $(600 \mathrm{MHz})$ spectrum of 1 in methanol- $d_{4}$. 


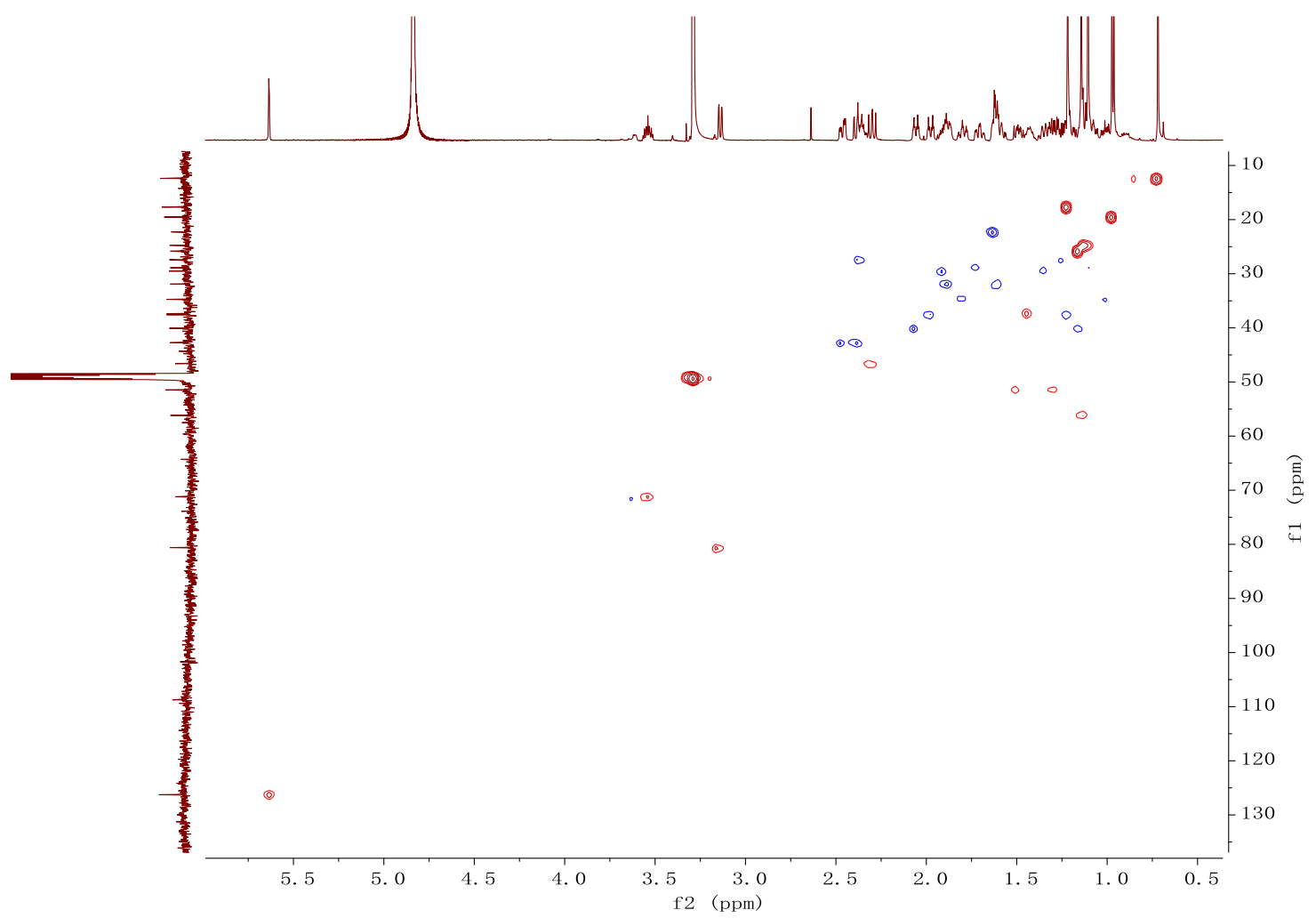

Figure S7. HSQC (600MHz) spectrum of $\mathbf{1}$ in methanol- $d_{4}$.

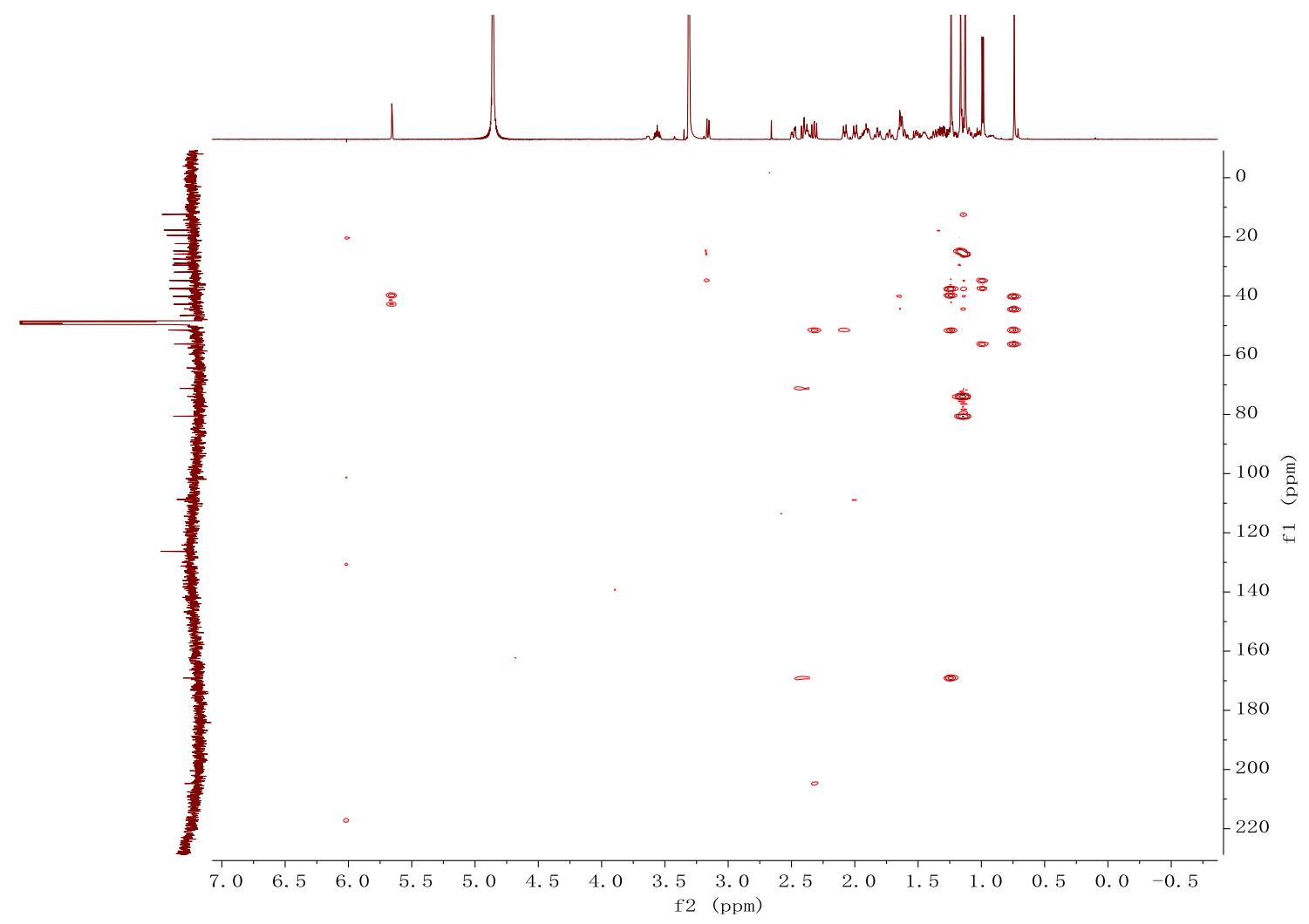

Figure S8. HMBC $(600 \mathrm{MHz})$ spectrum of $\mathbf{1}$ in methanol- $d_{4}$. 


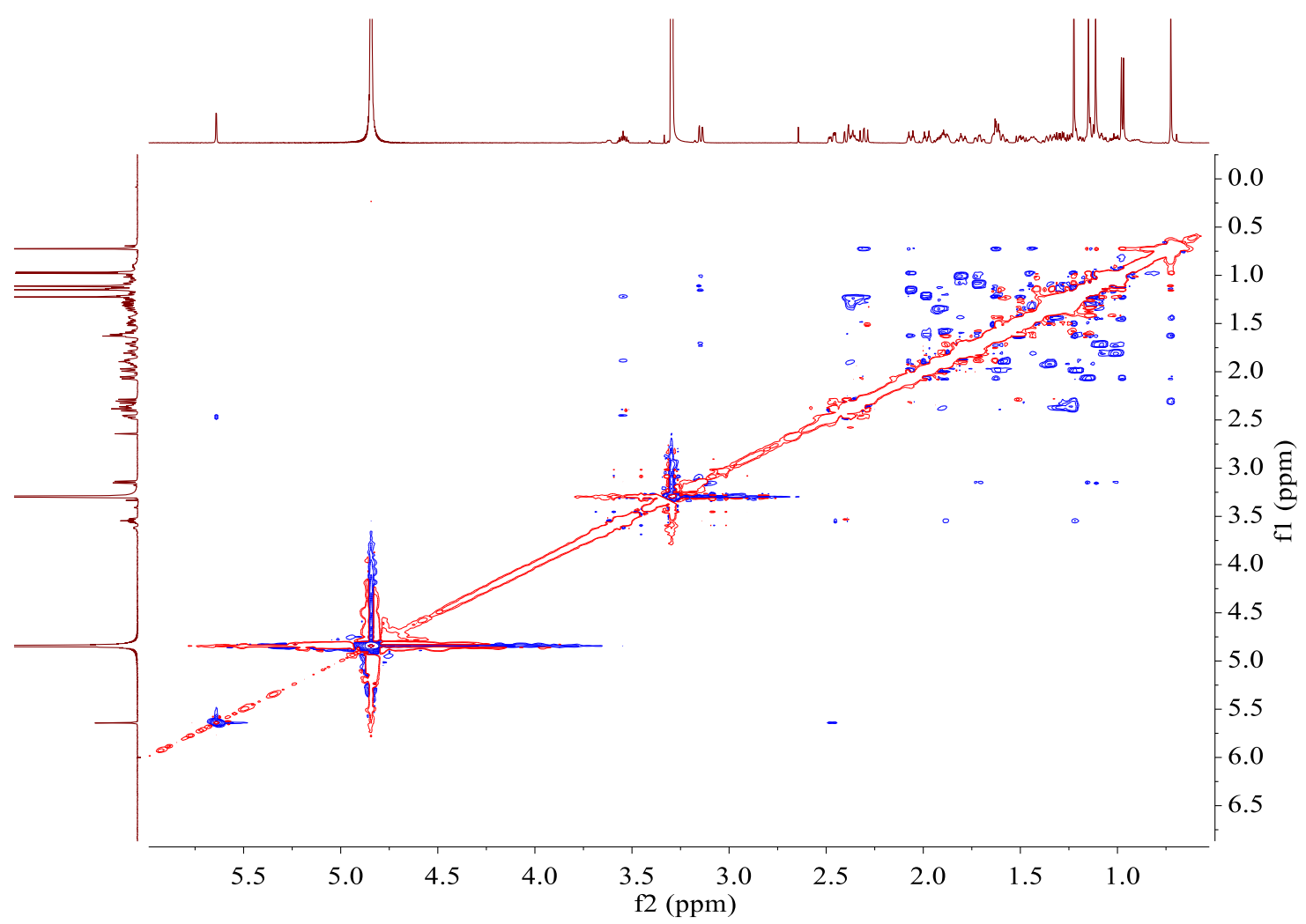

Figure S9. NOESY (600MHz) spectrum of $\mathbf{1}$ in methanol- $d_{4}$.

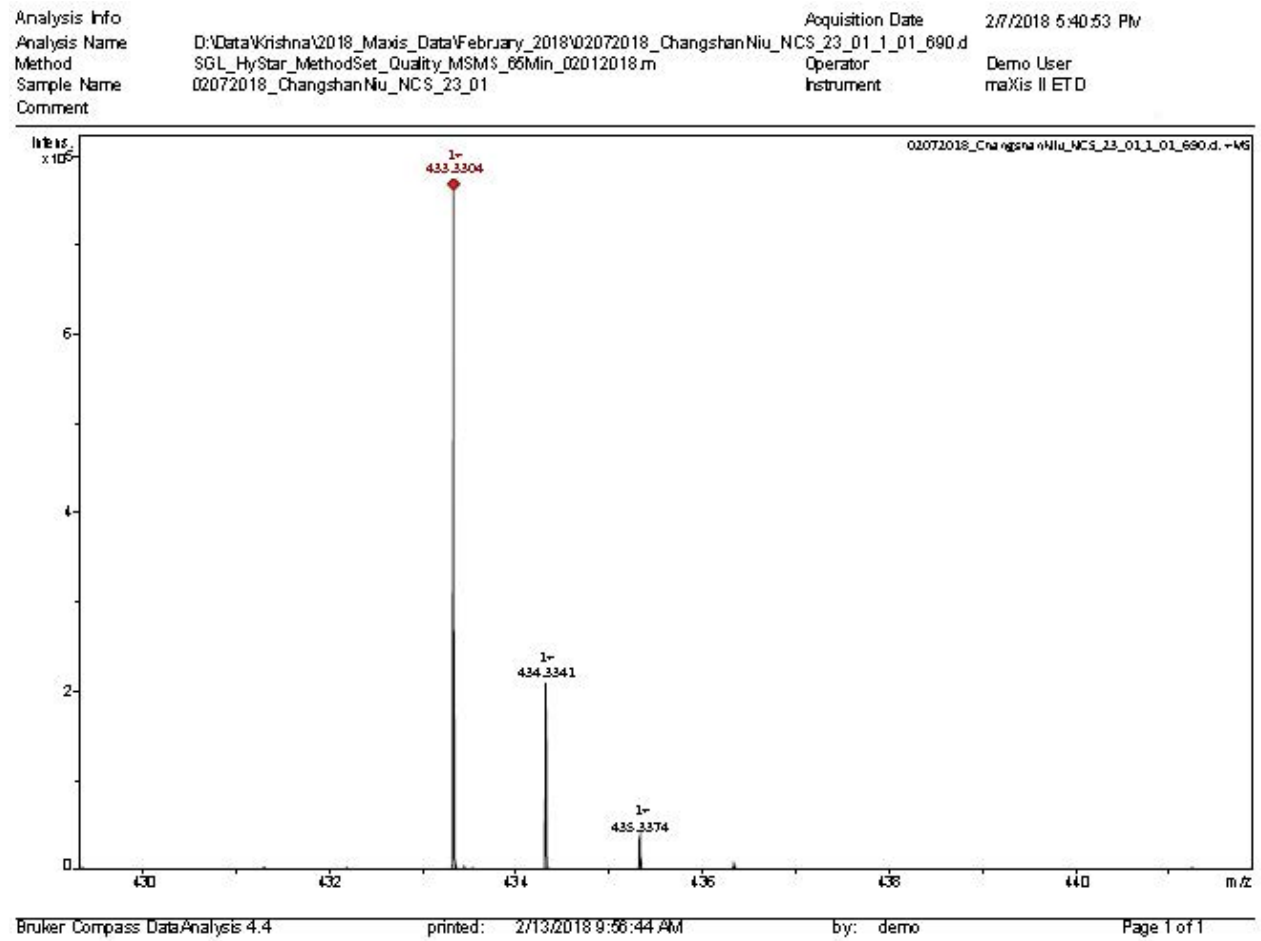

Figure S10. (+)-HRESIMS of 2 


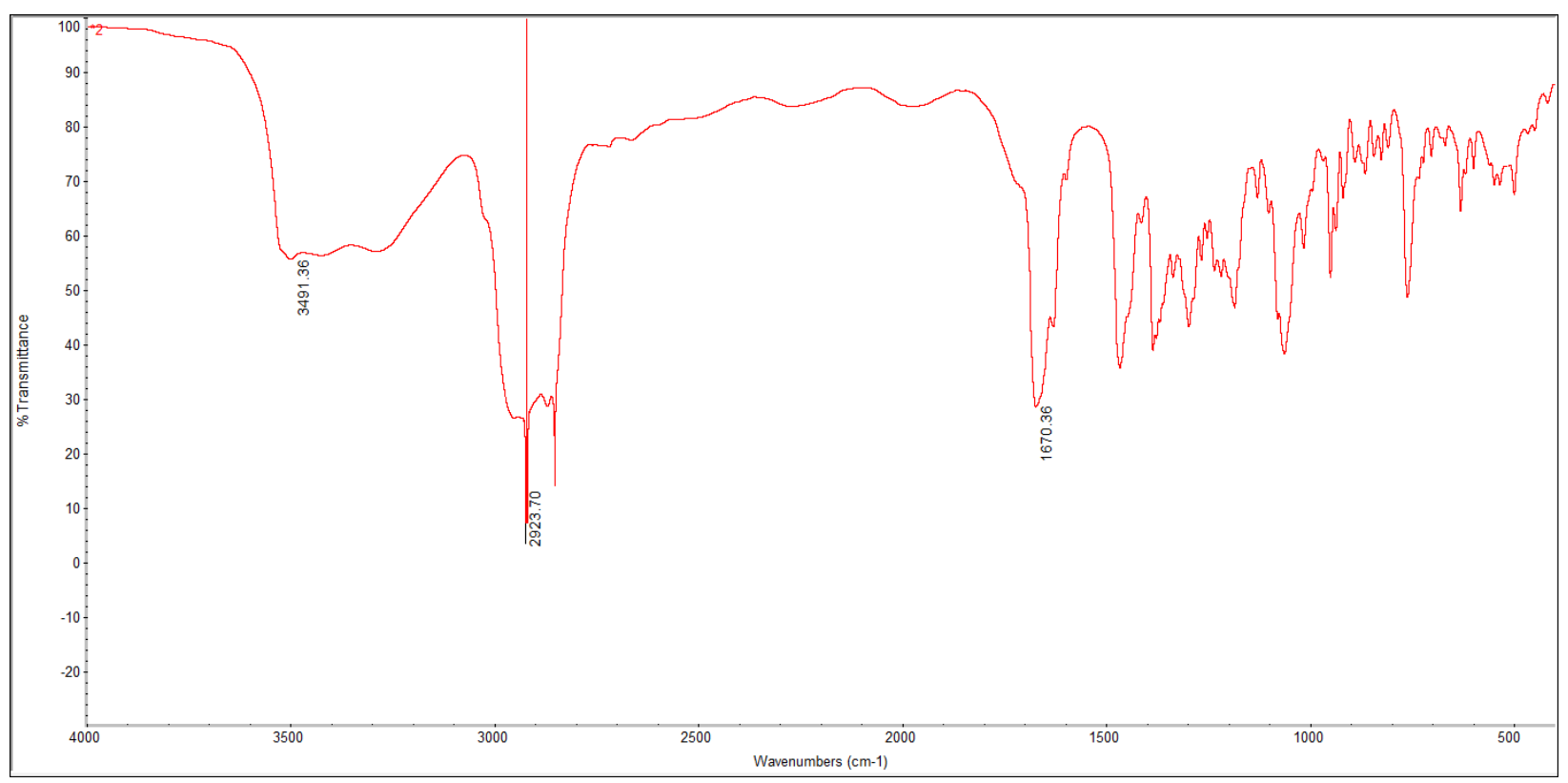

Figure S11. IR spectrum of 2.

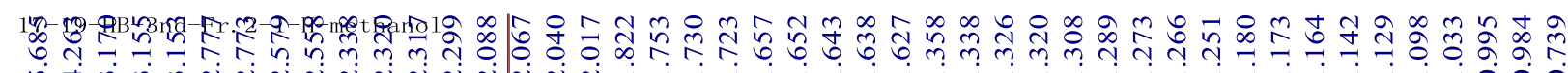

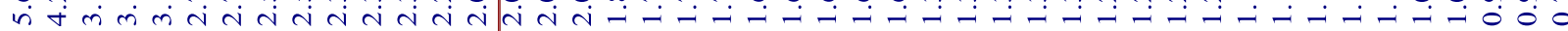

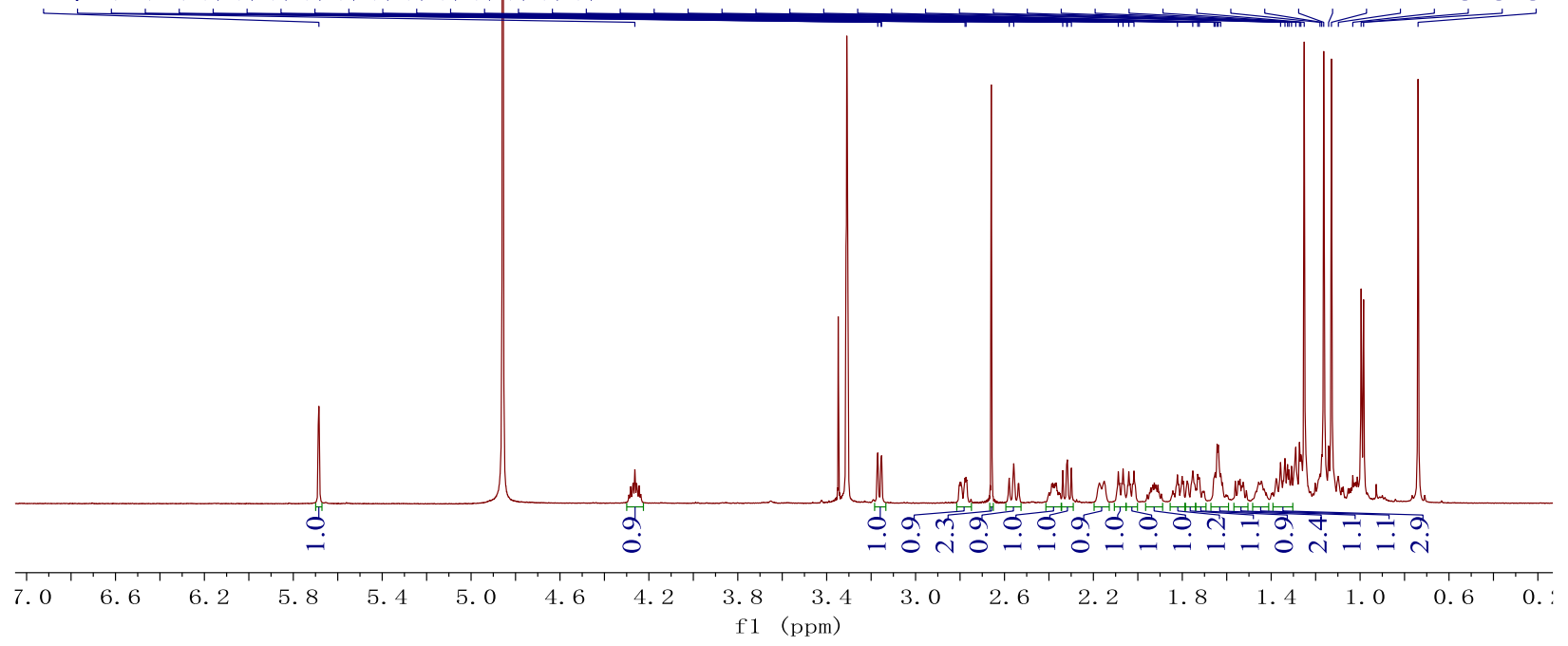

Figure S12. ${ }^{1} \mathrm{H}-\mathrm{NMR}(600 \mathrm{MHz})$ spectrum of $\mathbf{2}$ in methanol- $d_{4}$. 


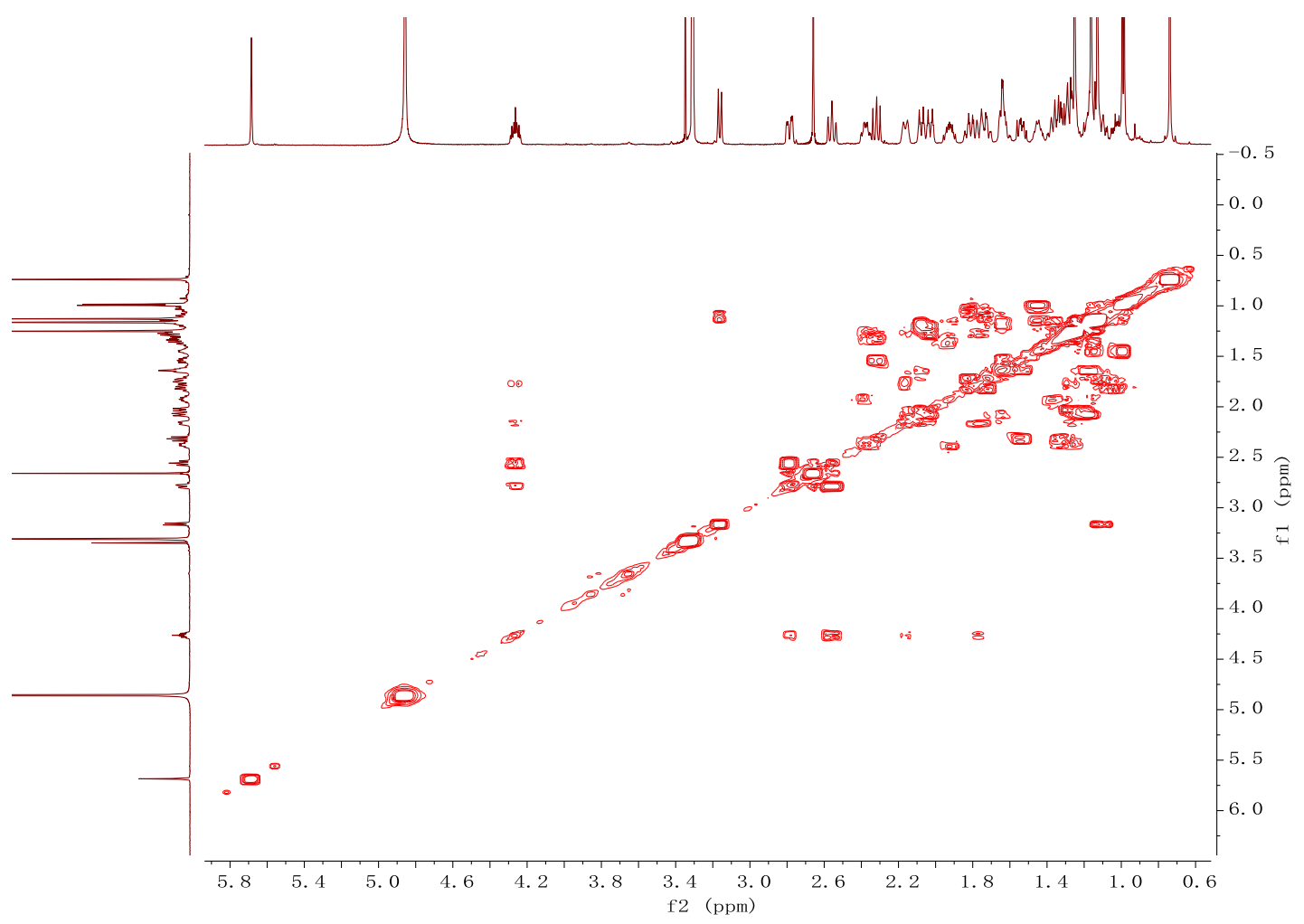

Figure S13. ${ }^{1} \mathrm{H}-{ }^{1} \mathrm{H}$ COSY $(600 \mathrm{MHz})$ spectrum of $\mathbf{2}$ in methanol- $d_{4}$.

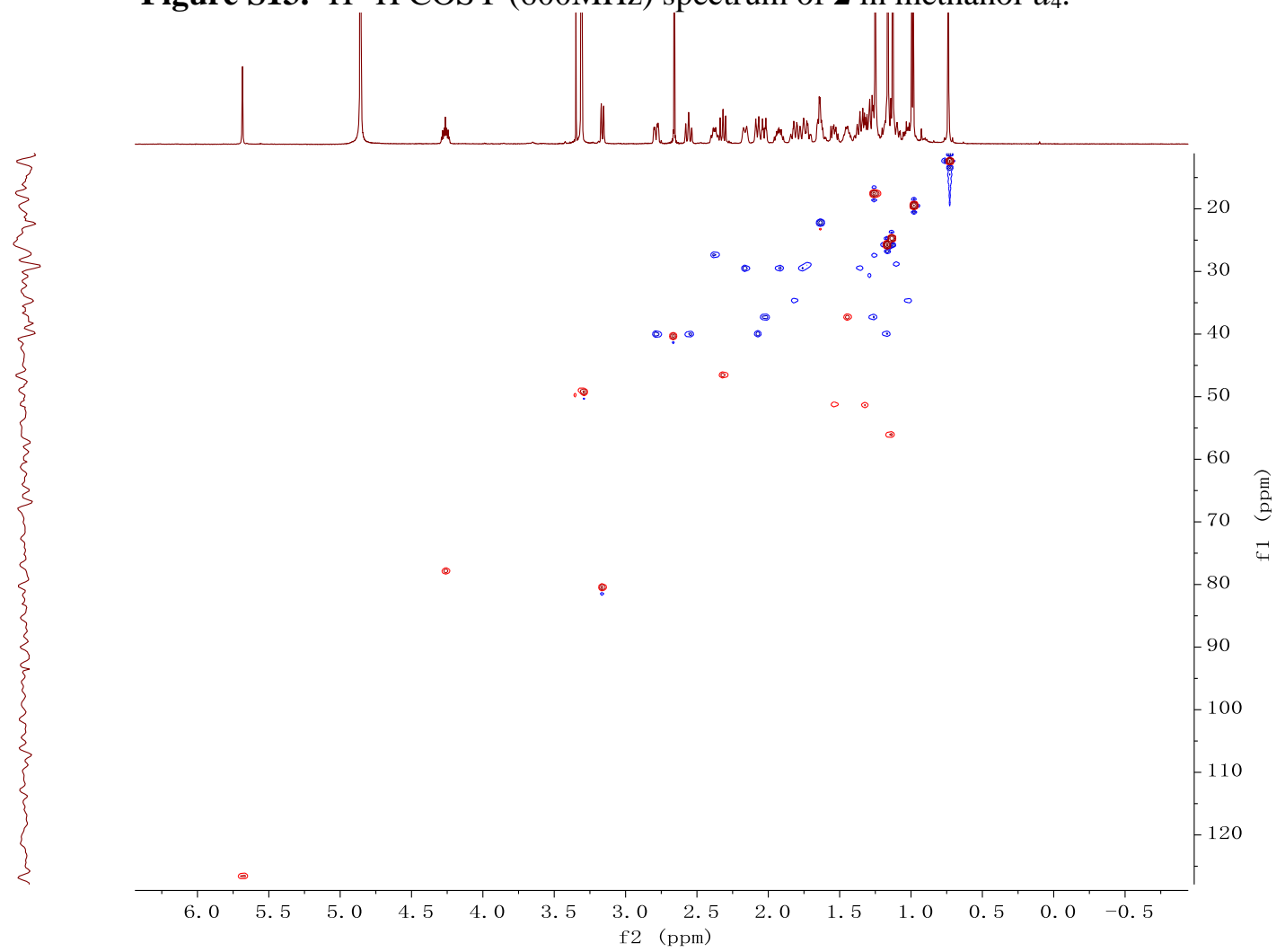

Figure S14. HSQC $(600 \mathrm{MHz})$ spectrum of 2 in methanol- $d_{4}$. 


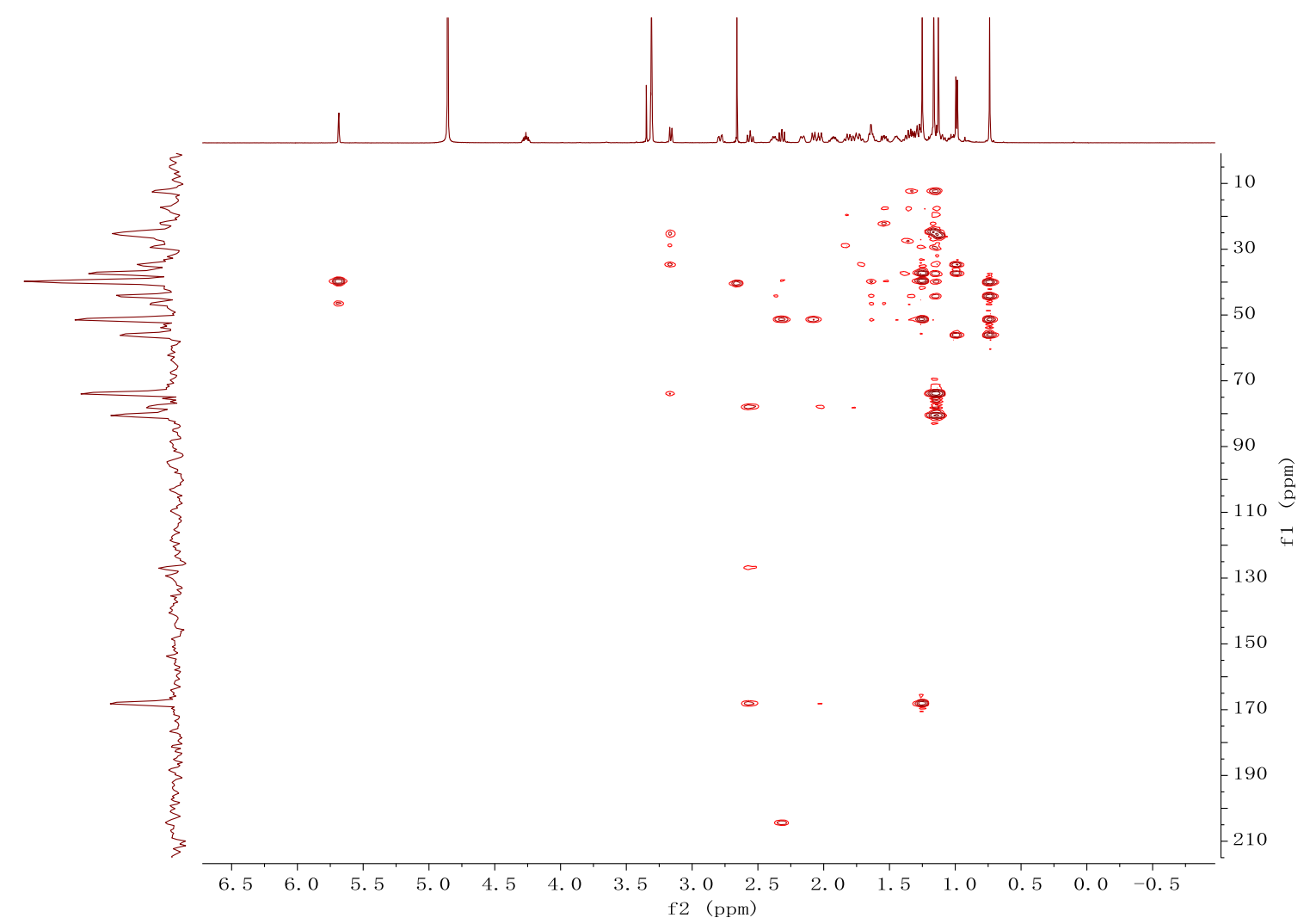

Figure S15. HMBC (600MHz) spectrum of 2 in methanol- $d_{4}$.

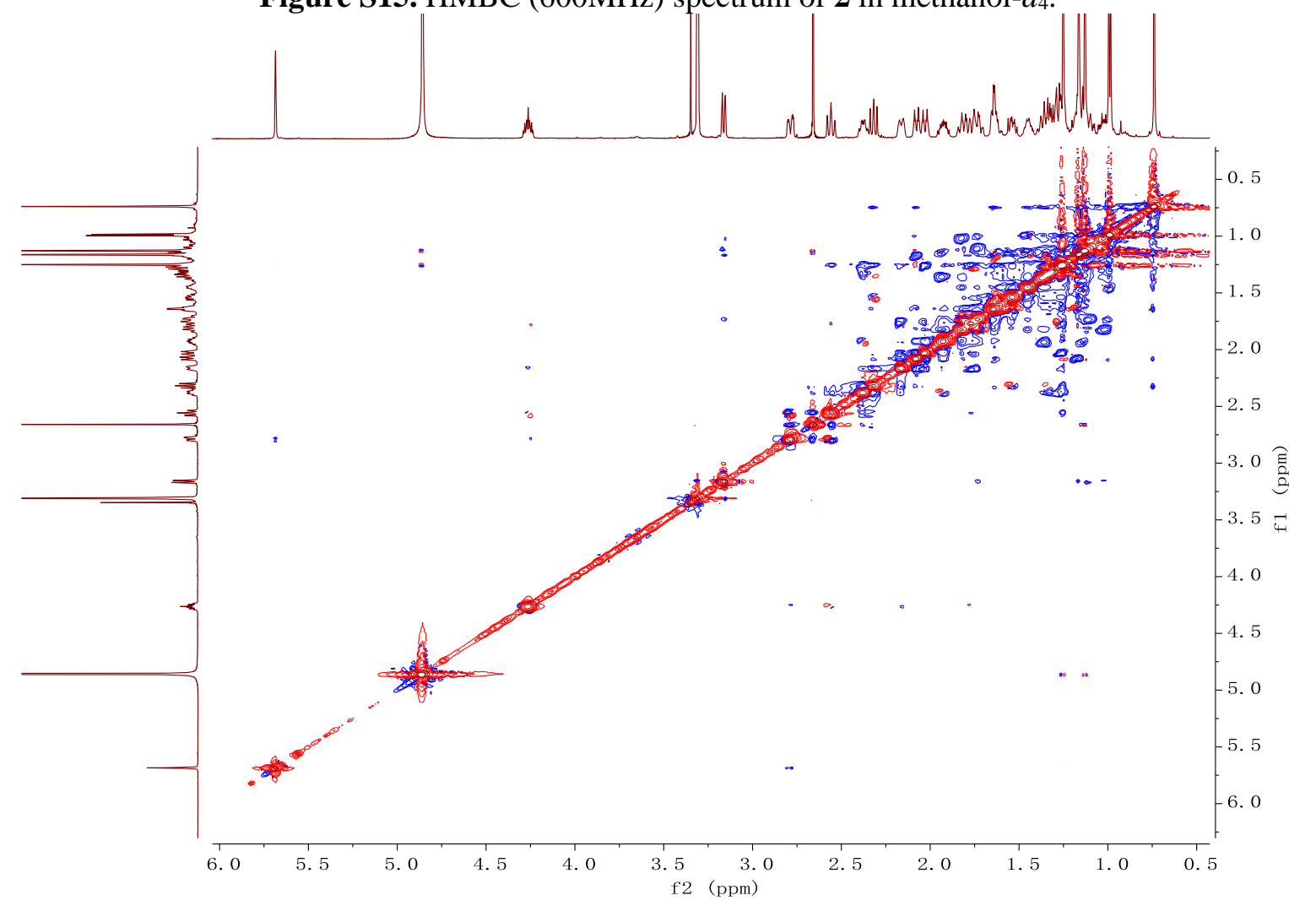

Figure S16. NOESY $(600 \mathrm{MHz})$ spectrum of $\mathbf{2}$ in methanol- $d_{4}$. 


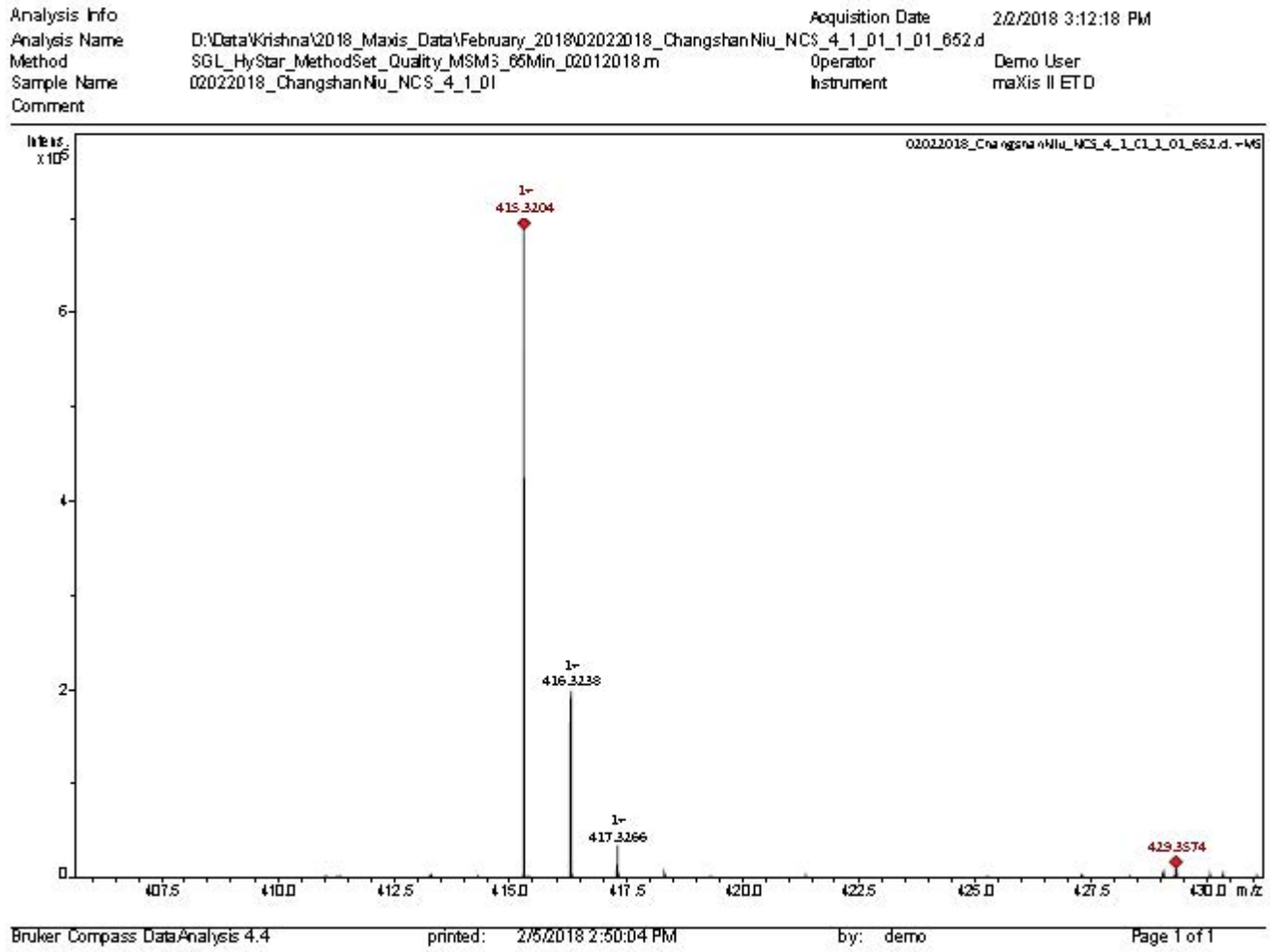

Figure S17. (+)-HRESIMS of 3.

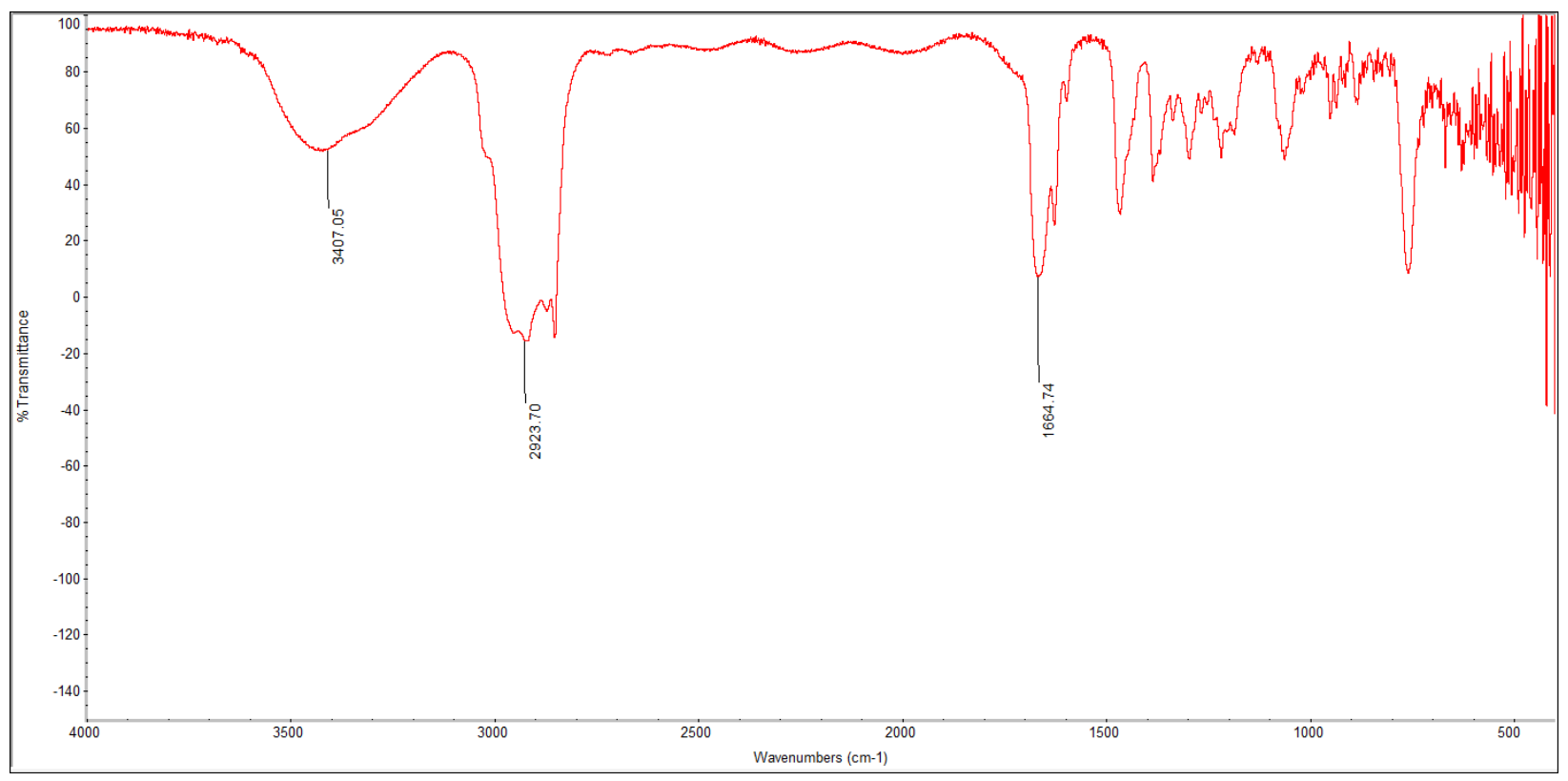

Figure S18. IR spectrum of 3. 


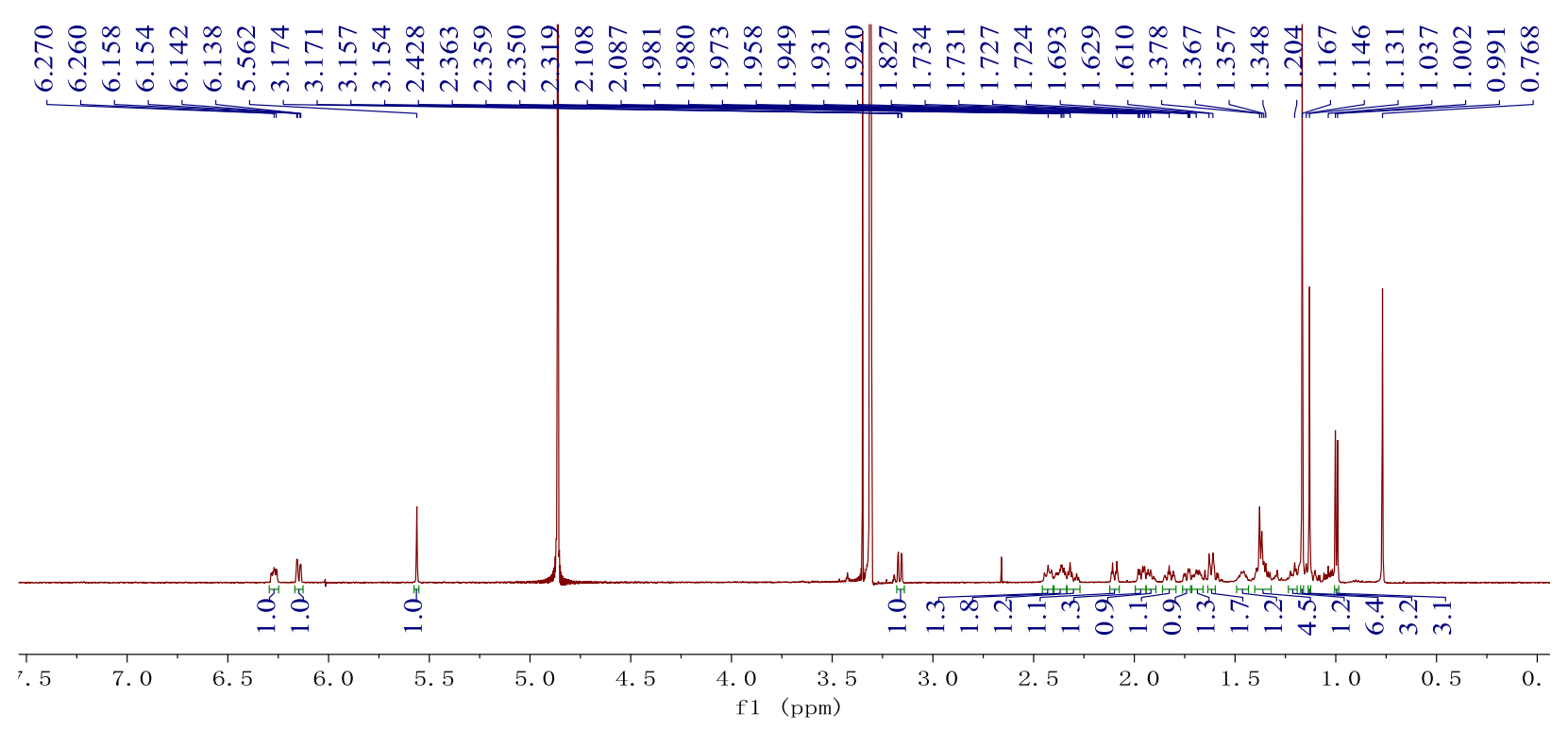

Figure S19. ${ }^{1} \mathrm{H}-\mathrm{NMR}(600 \mathrm{MHz})$ spectrum of $\mathbf{3}$ in methanol- $d_{4}$.

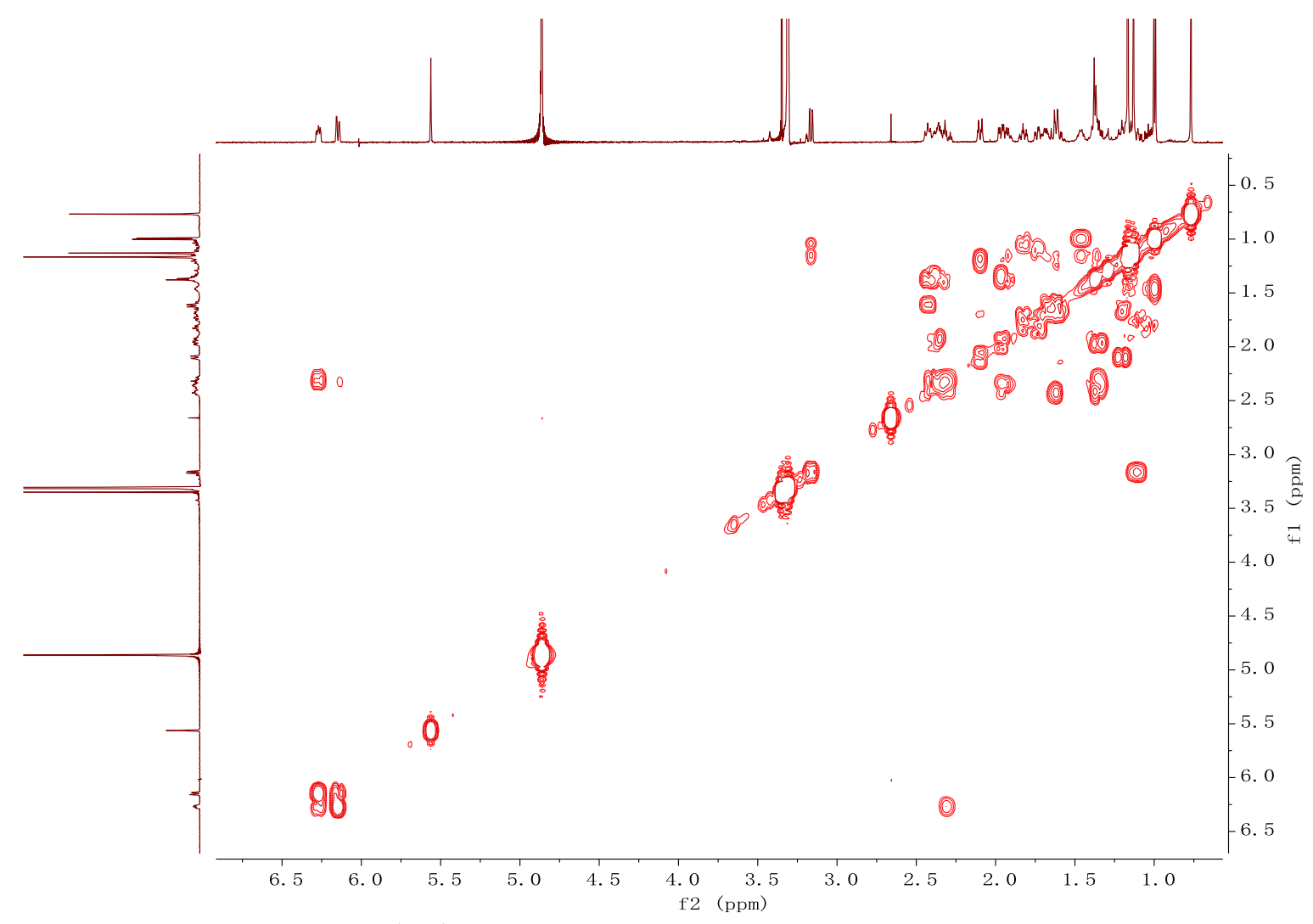

Figure S20. ${ }^{1} \mathrm{H}-{ }^{1} \mathrm{H}$ COSY $(600 \mathrm{MHz})$ spectrum of 3 in methanol- $d_{4}$. 


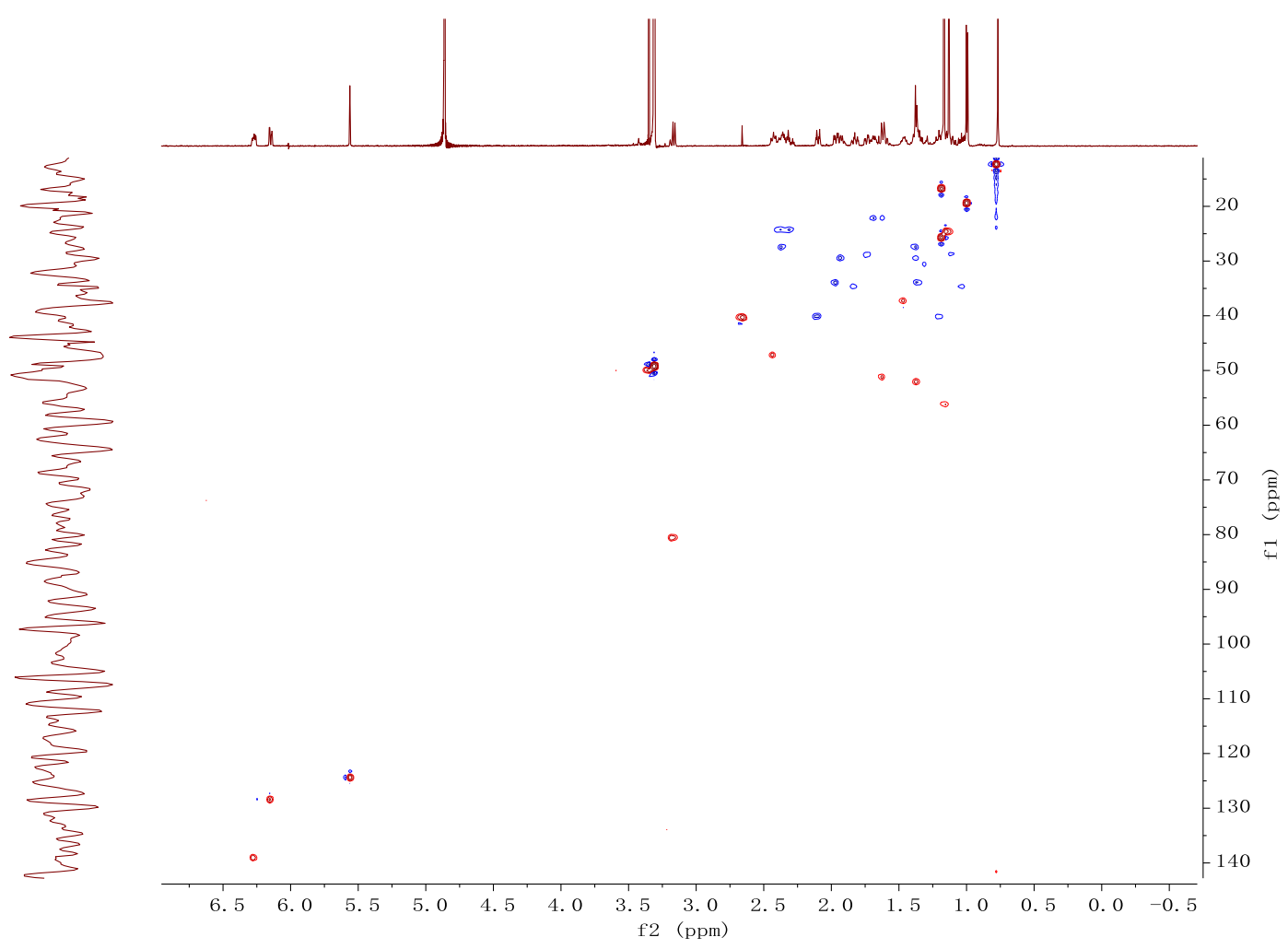

Figure S21. HSQC (600MHz) spectrum of $\mathbf{3}$ in methanol- $d_{4}$.

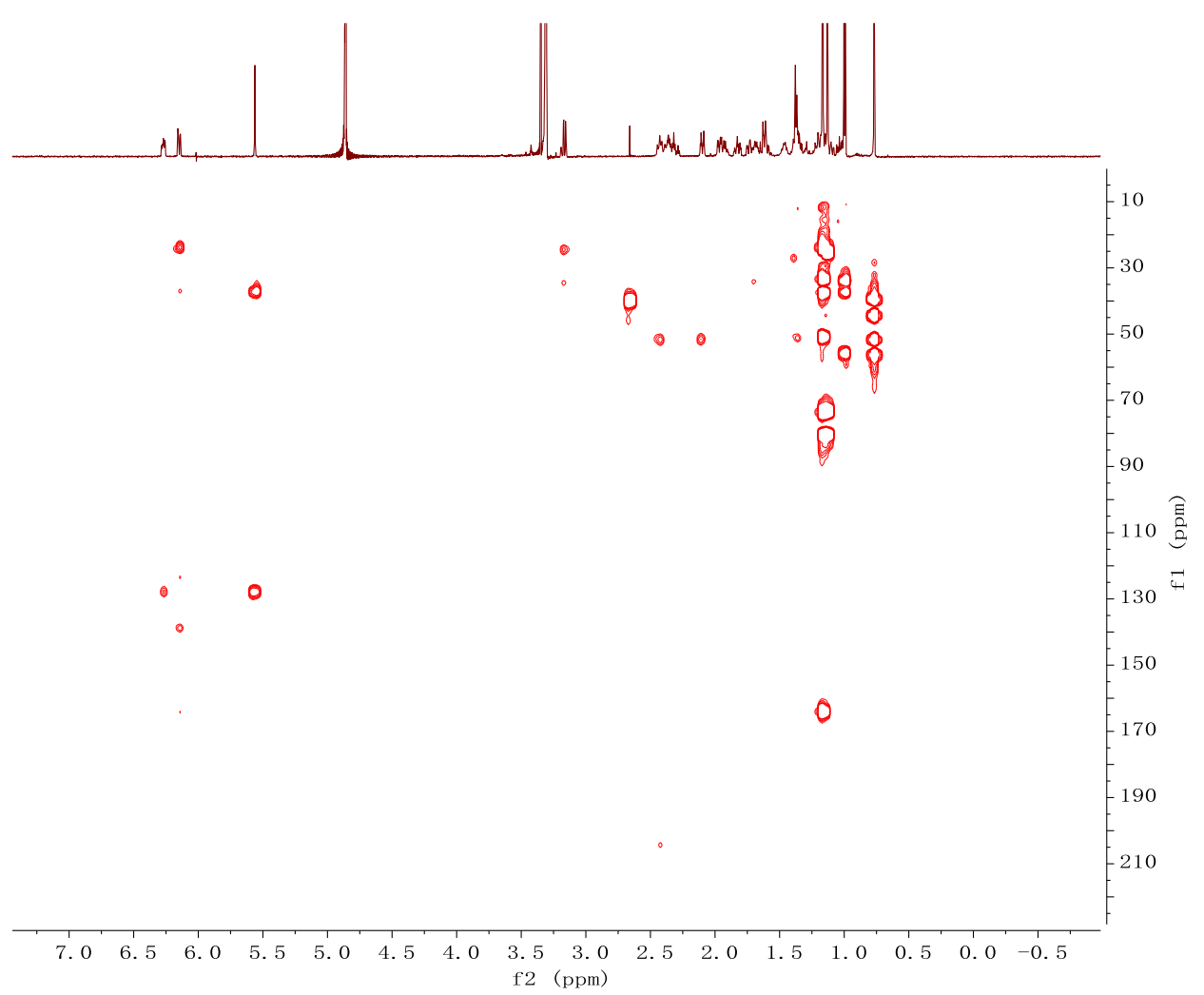

Figure S22. HMBC (600MHz) spectrum of $\mathbf{3}$ in methanol- $d_{4}$. 


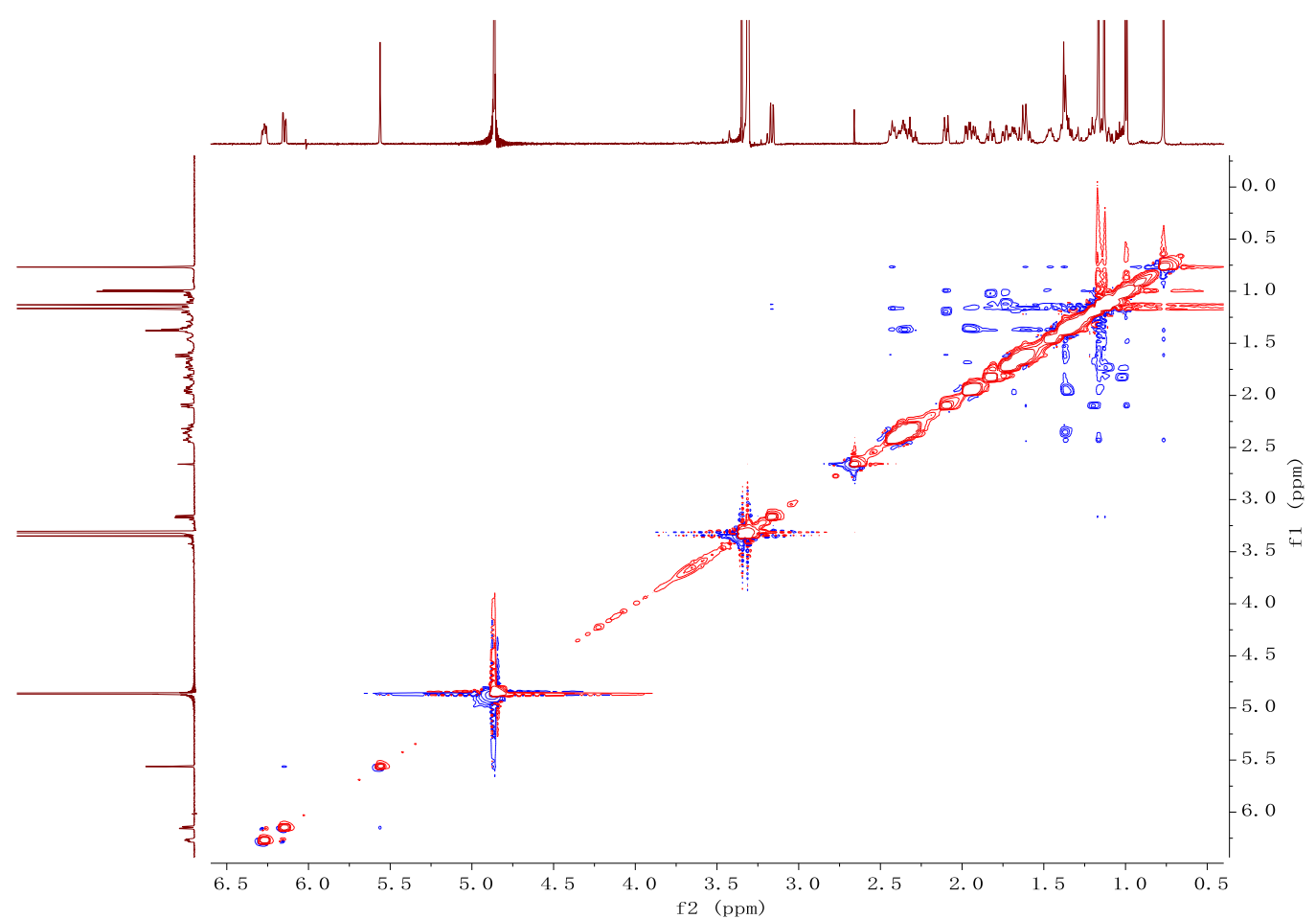

Figure S23. NOESY $(600 \mathrm{MHz})$ spectrum of 3 in methanol- $d_{4}$.

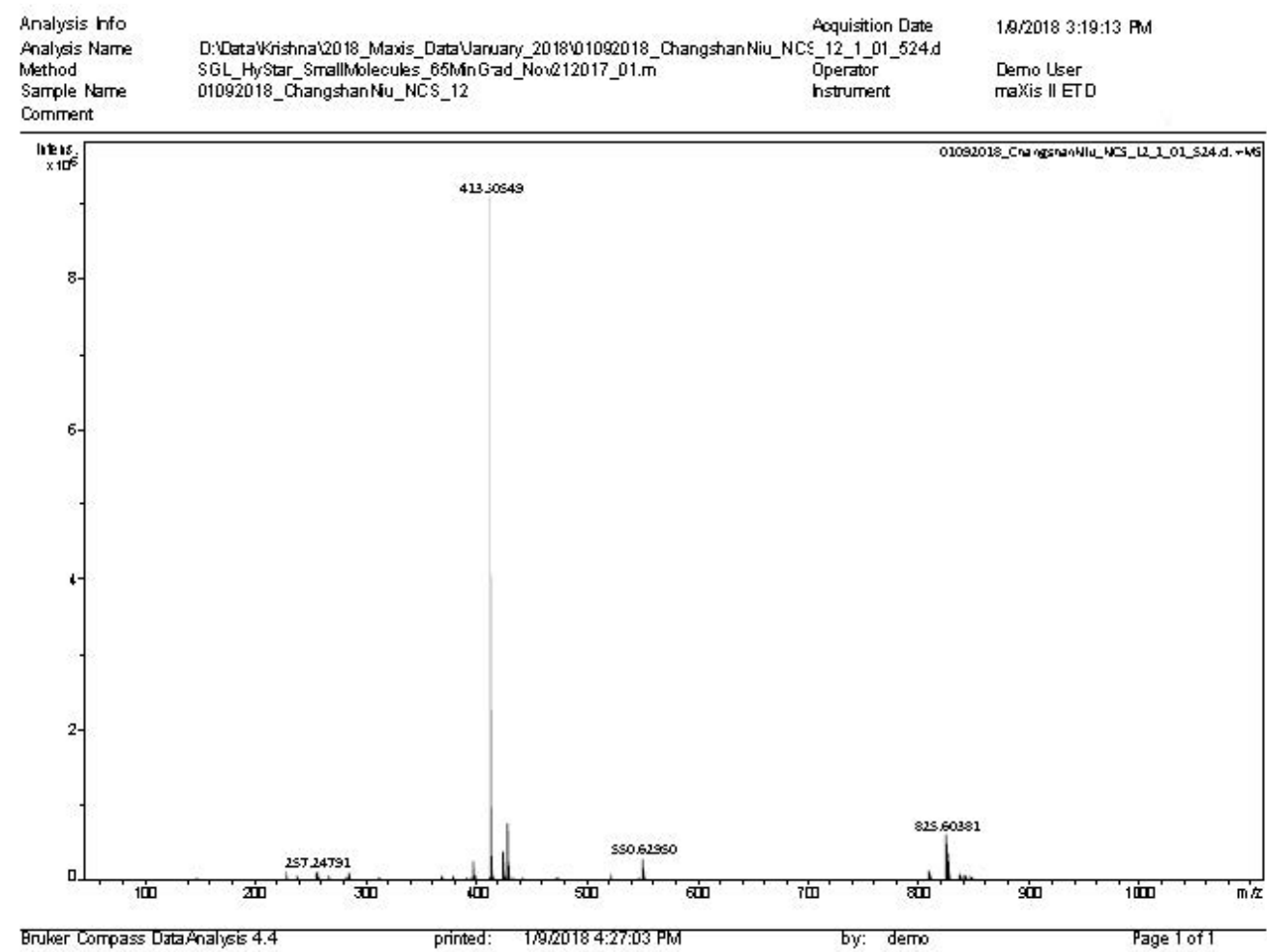

Figure S24. (+)-HRESIMS of 4. 


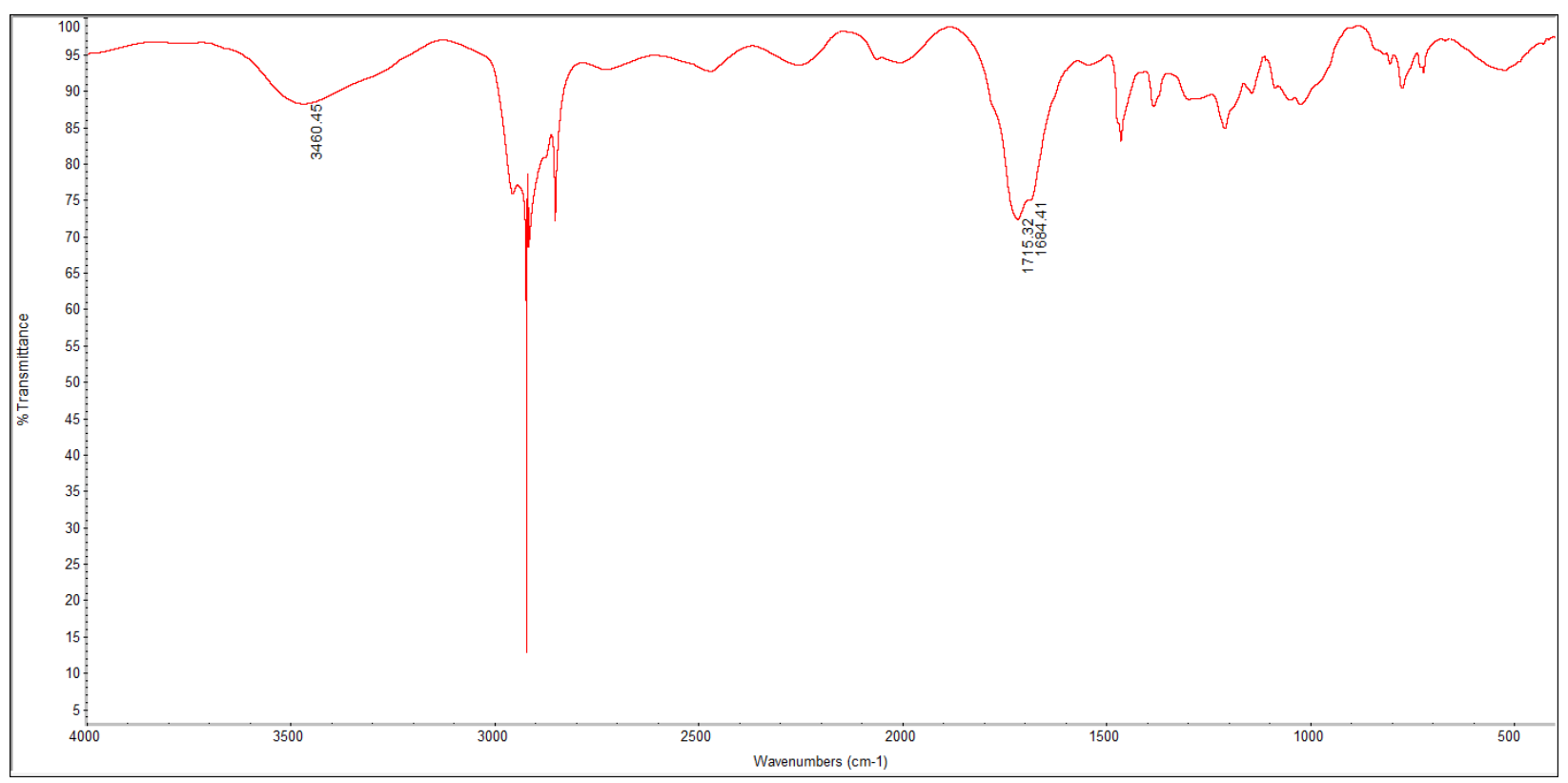

Figure S25. IR spectrum of 4 .

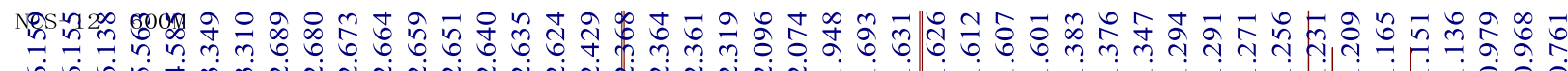

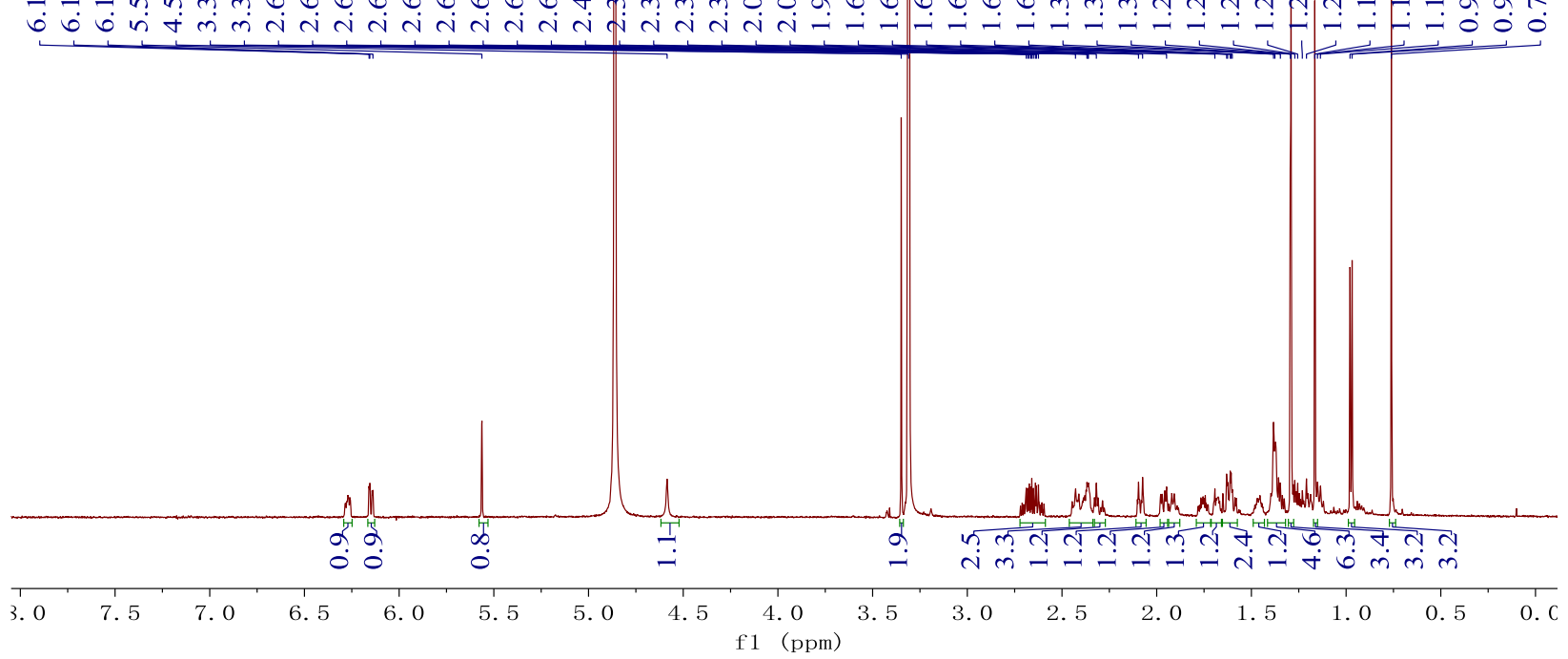

Figure S26. ${ }^{1} \mathrm{H}-\mathrm{NMR}(600 \mathrm{MHz})$ spectrum of 4 in methanol- $d_{4}$. 


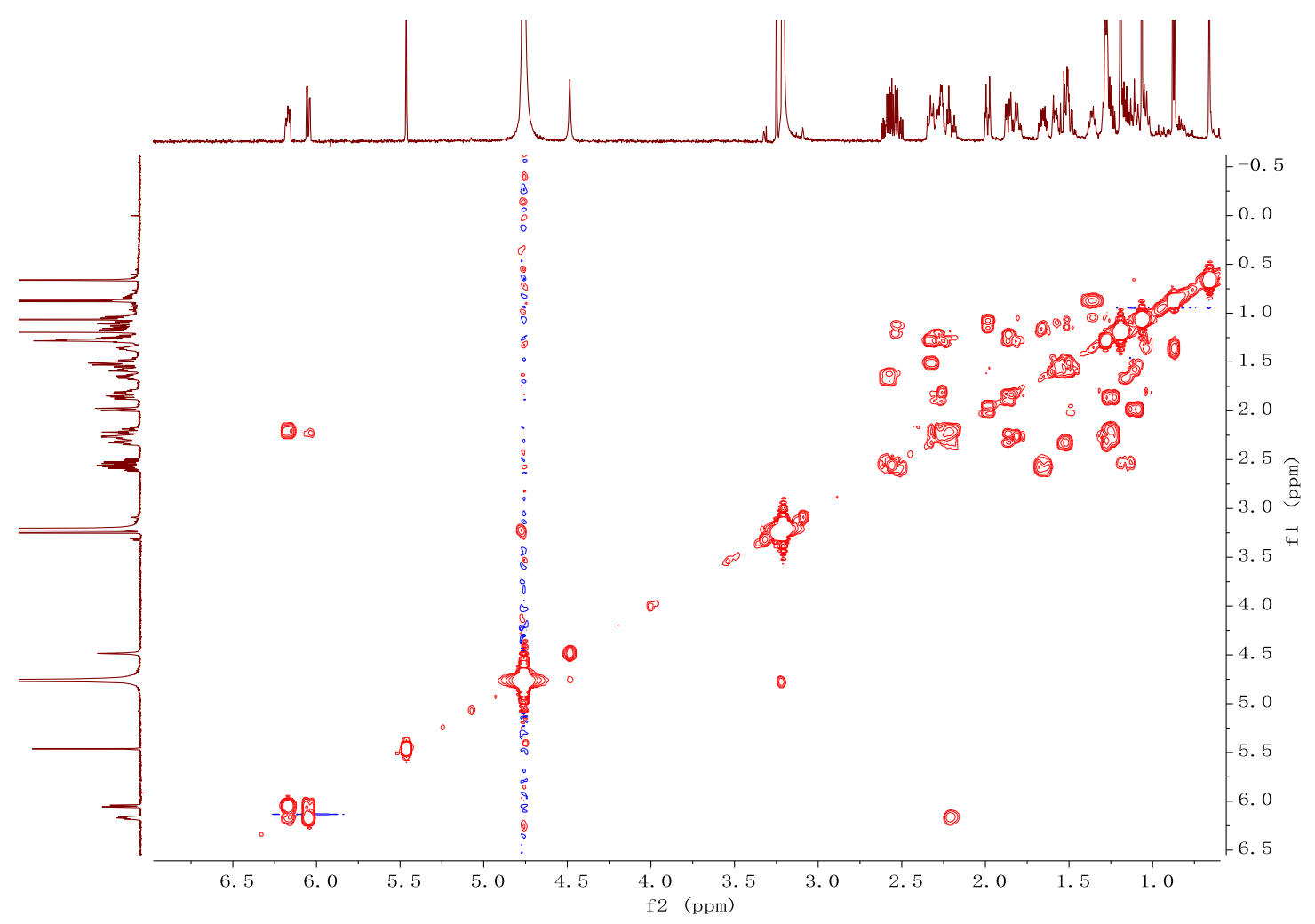

Figure S27. ${ }^{1} \mathrm{H}-{ }^{1} \mathrm{H}$ COSY $(600 \mathrm{MHz})$ spectrum of 4 in methanol- $d_{4}$.

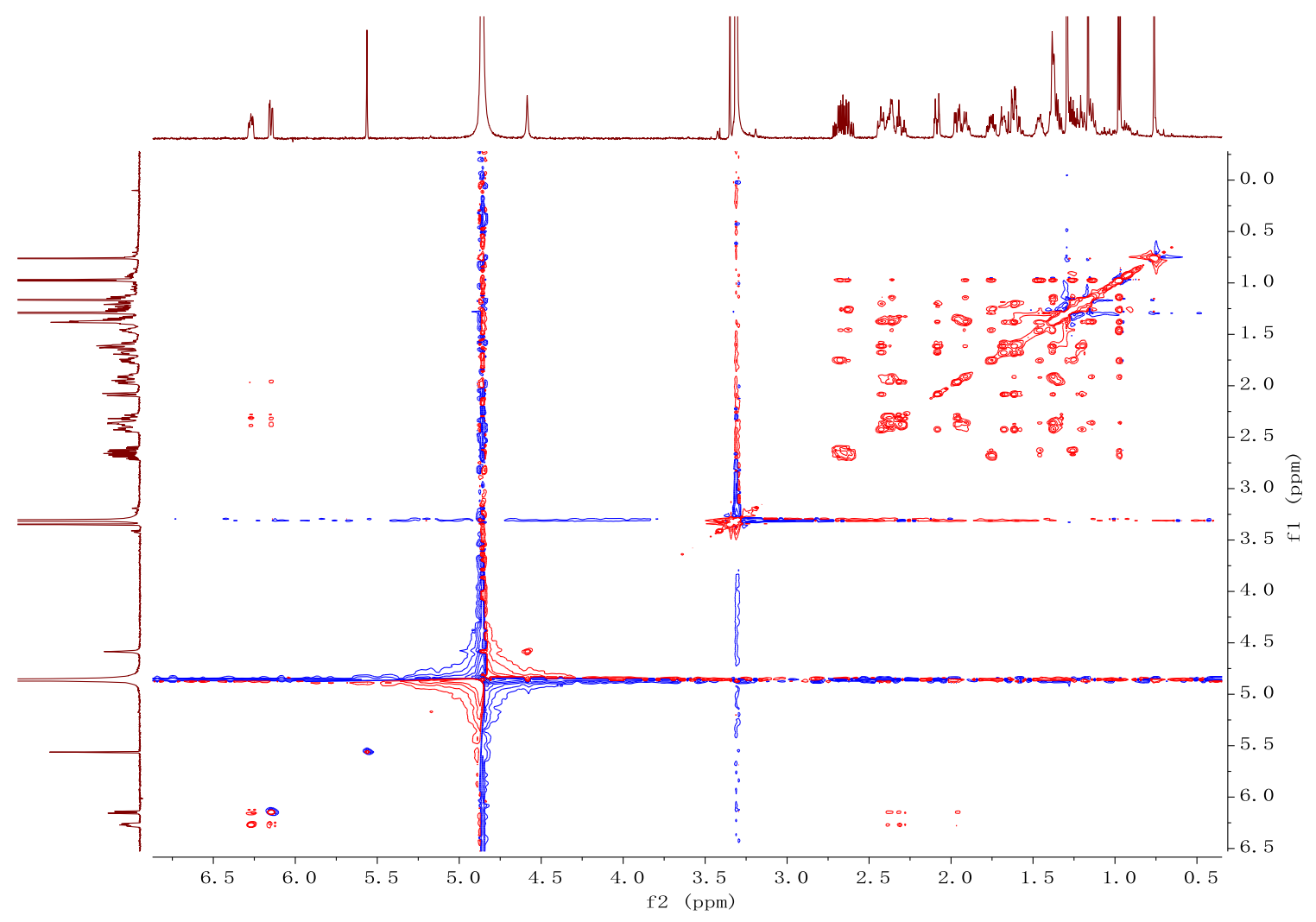

Figure S28. TOCSY (600MHz) spectrum of $\mathbf{4}$ in methanol- $d_{4}$. 


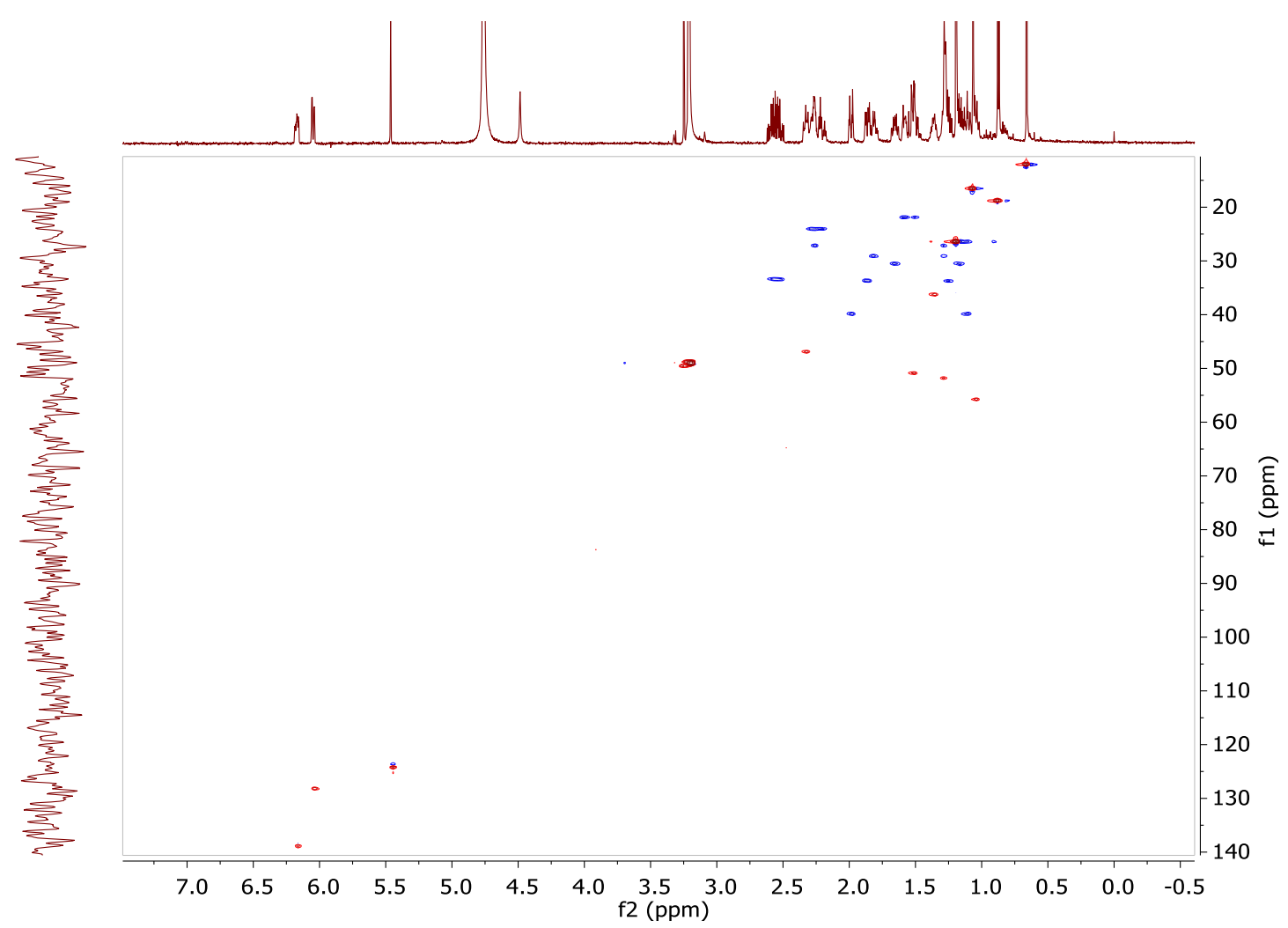

Figure S29. HSQC (600MHz) spectrum of 4 in methanol- $d_{4}$.

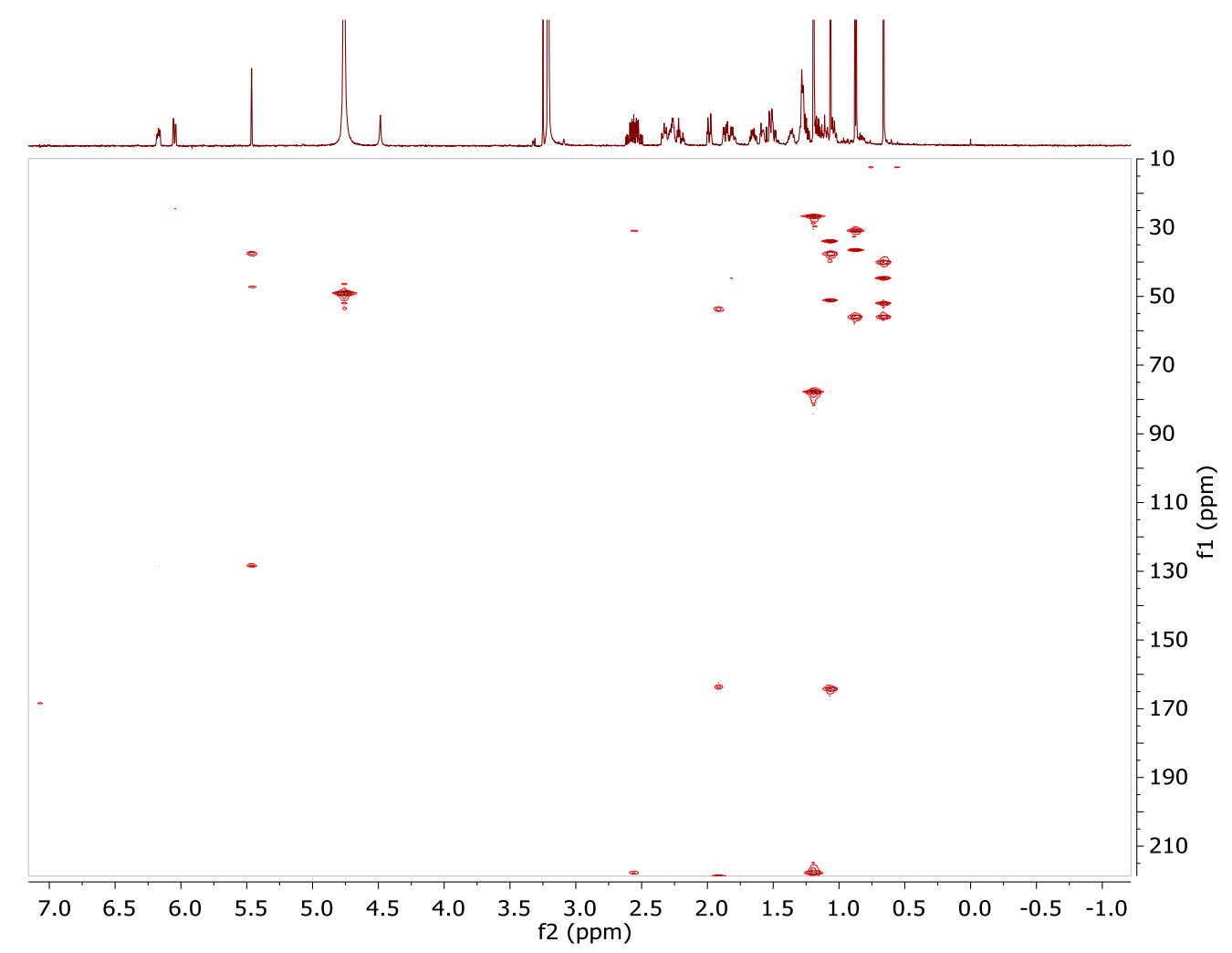

Figure S30. HMBC $(600 \mathrm{MHz})$ spectrum of $\mathbf{4}$ in methanol- $d_{4}$. 


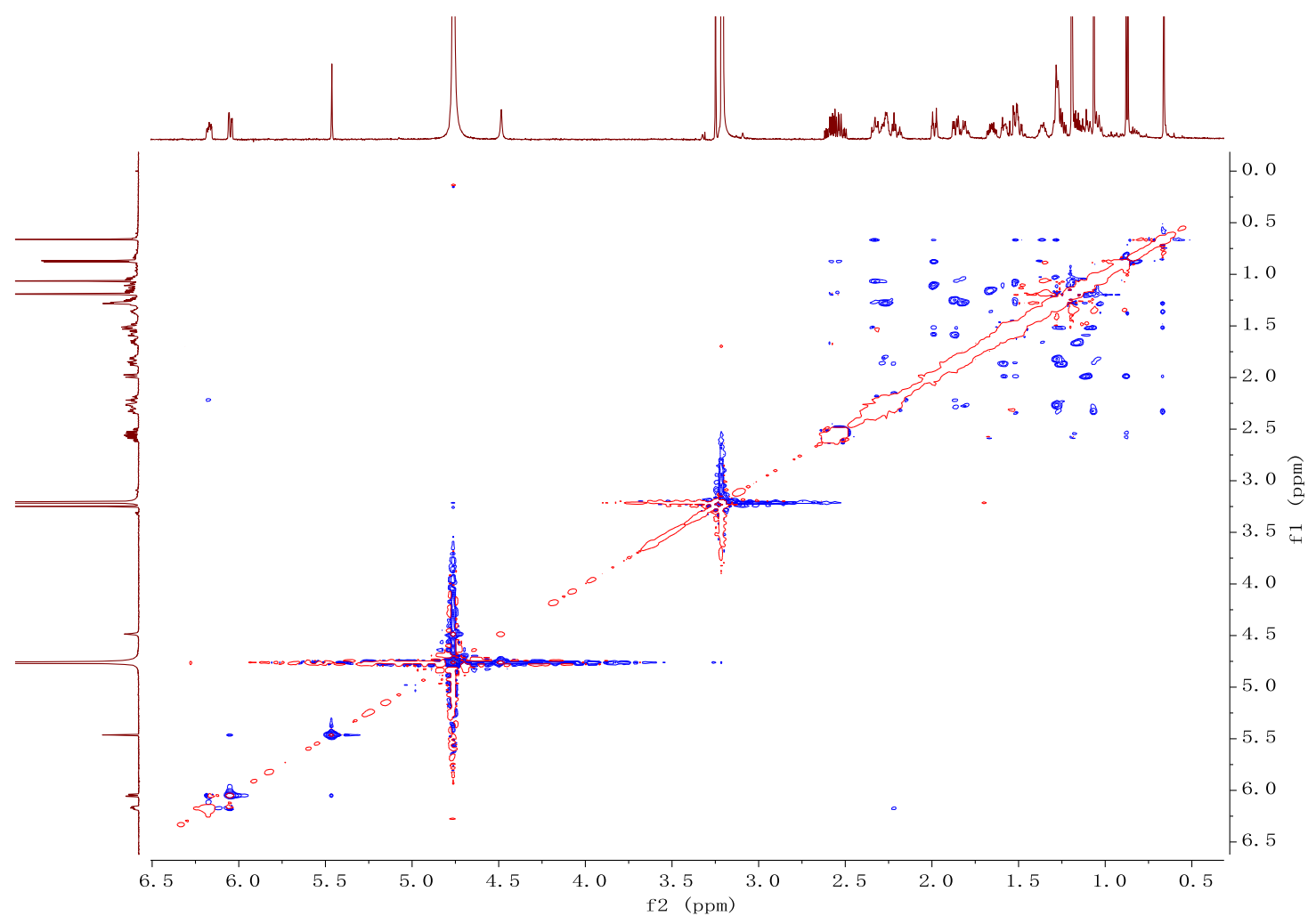

Figure S31. NOESY (600MHz) spectrum of 4 in methanol- $d_{4}$.

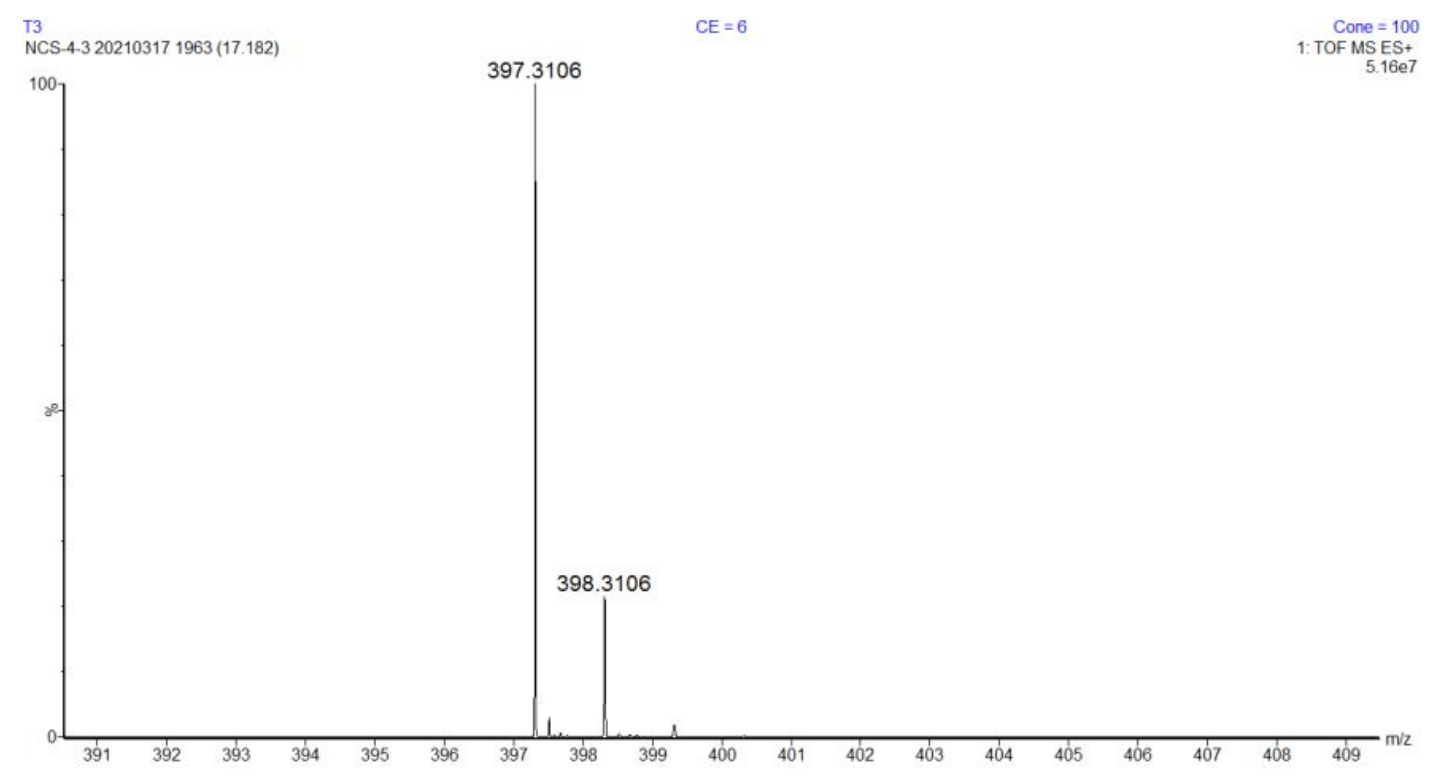

Figure S32. (+)-HRESIMS of 5. 


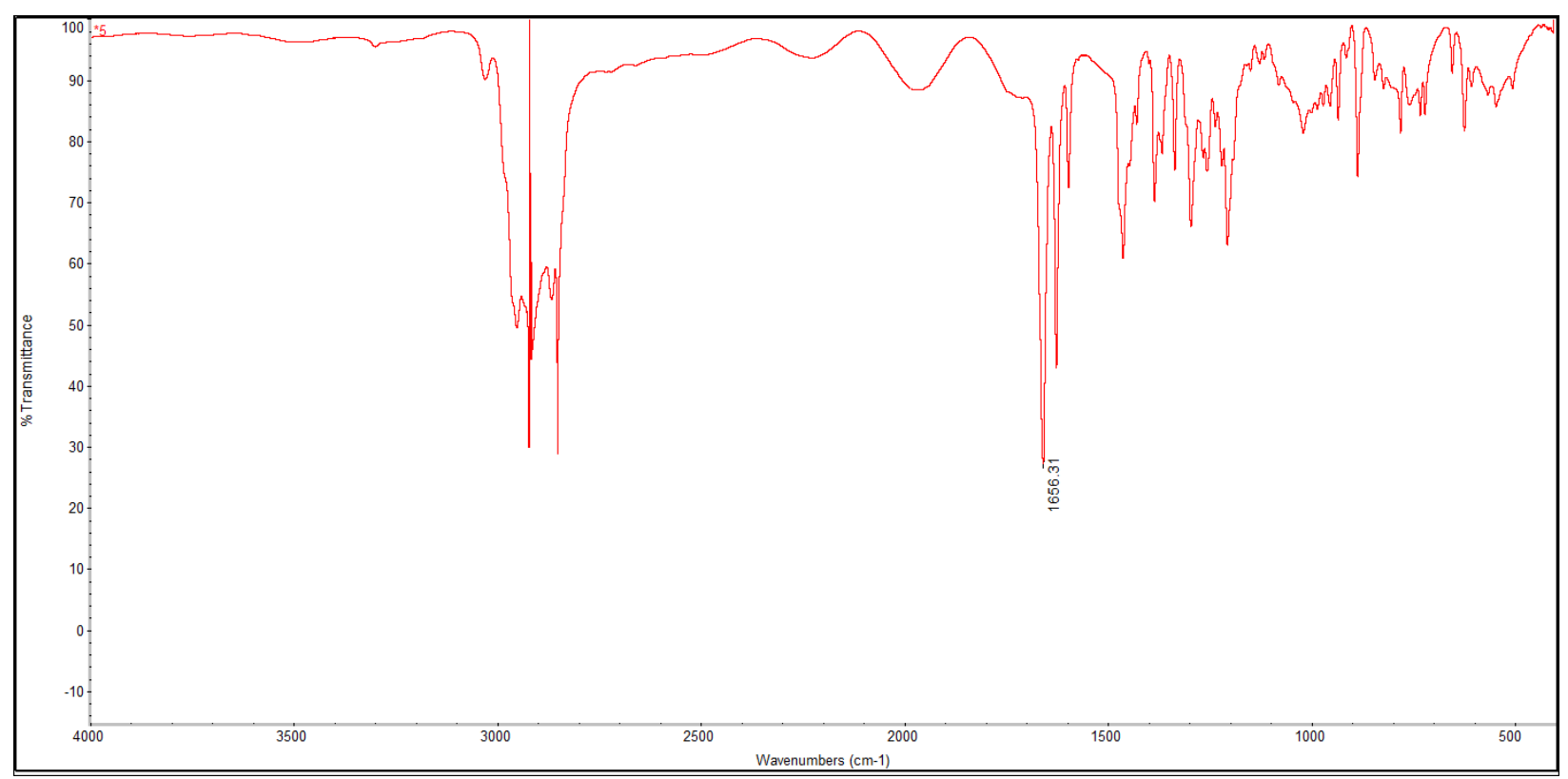

Figure S33. IR spectrum of 5.

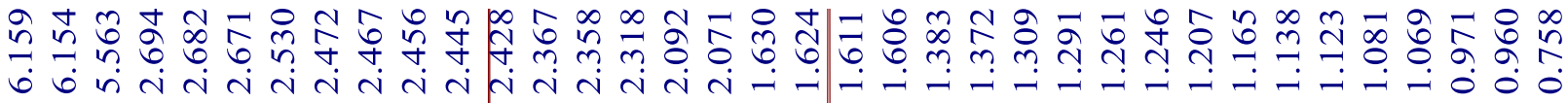

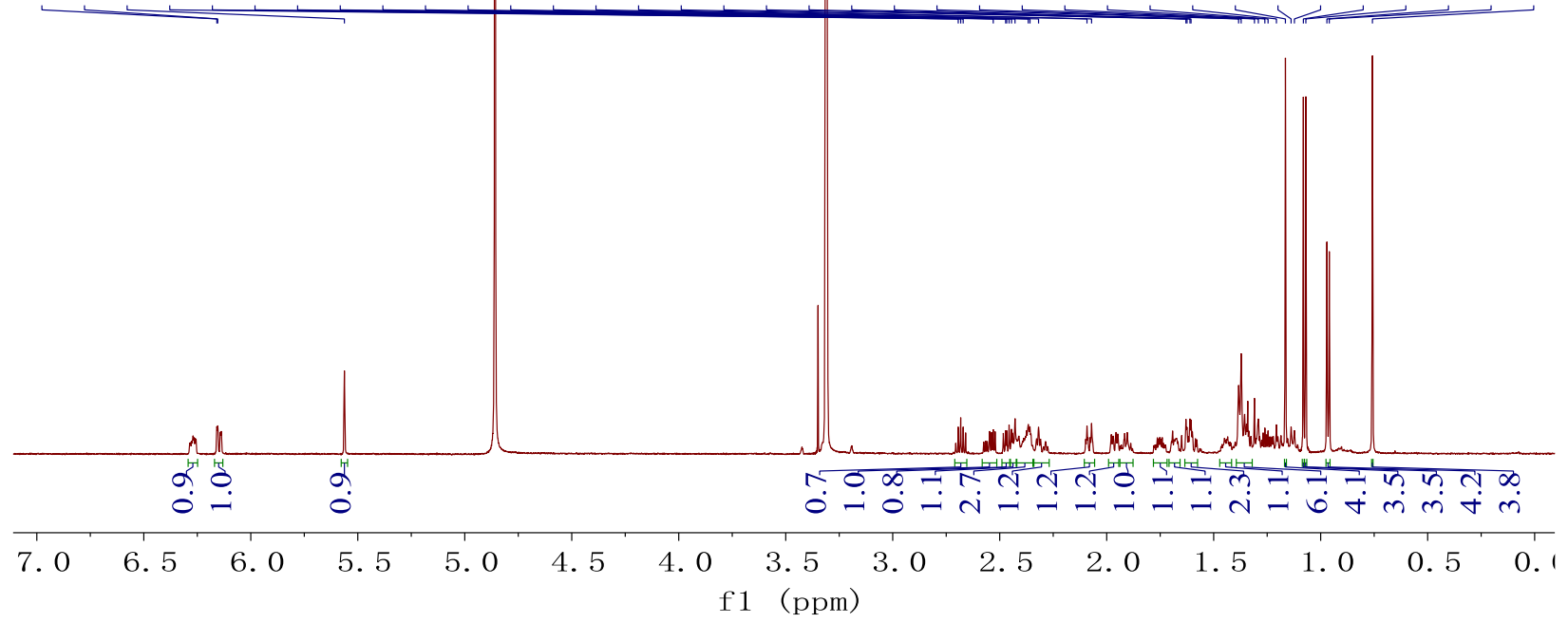

Figure S34. ${ }^{1} \mathrm{H}-\mathrm{NMR}(600 \mathrm{MHz})$ of 5 in methanol- $d_{4}$. 


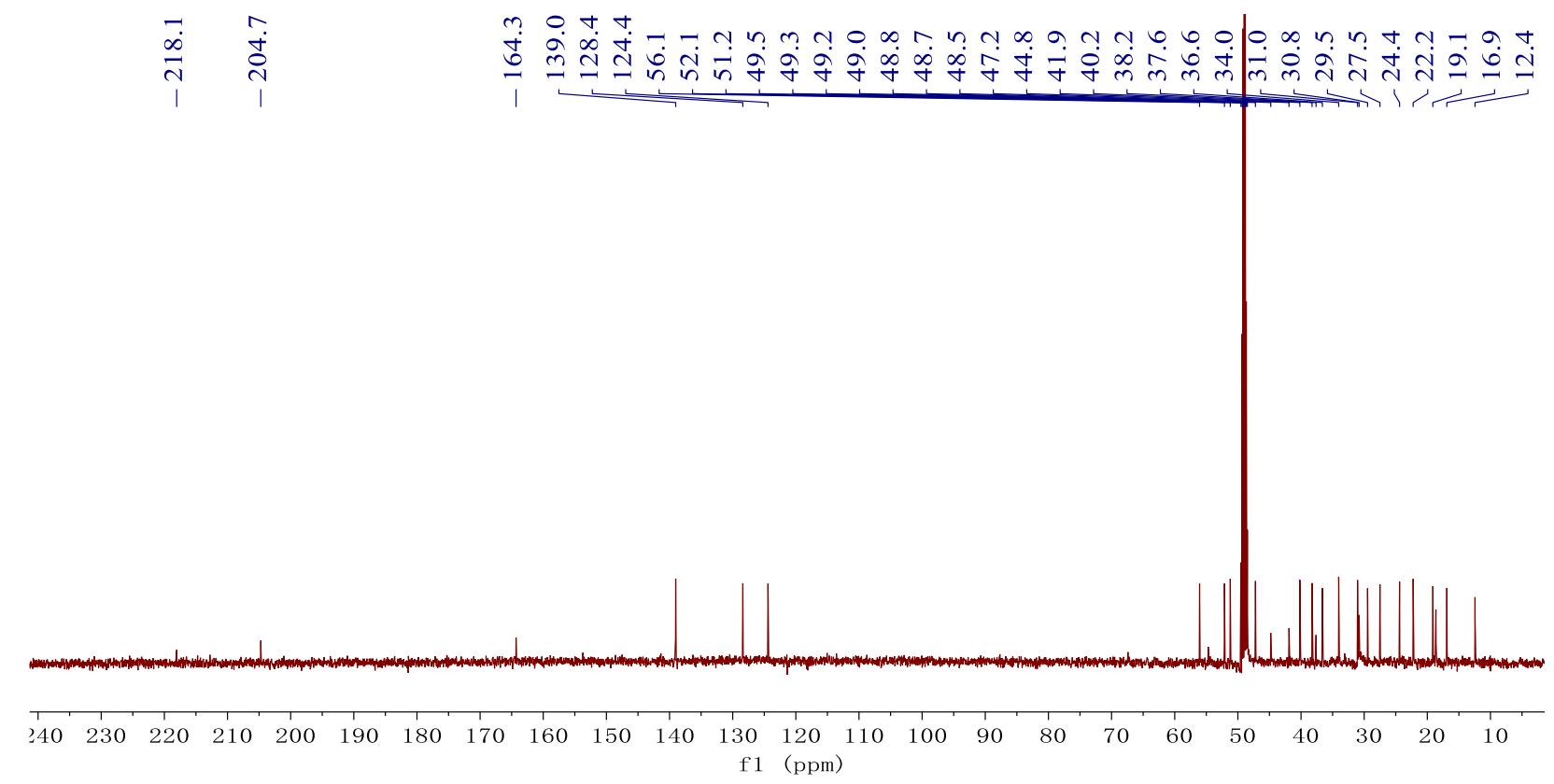

Figure S35. ${ }^{13} \mathrm{C}-\mathrm{NMR}(125 \mathrm{MHz})$ spectrum of 5 in methanol- $d_{4}$.

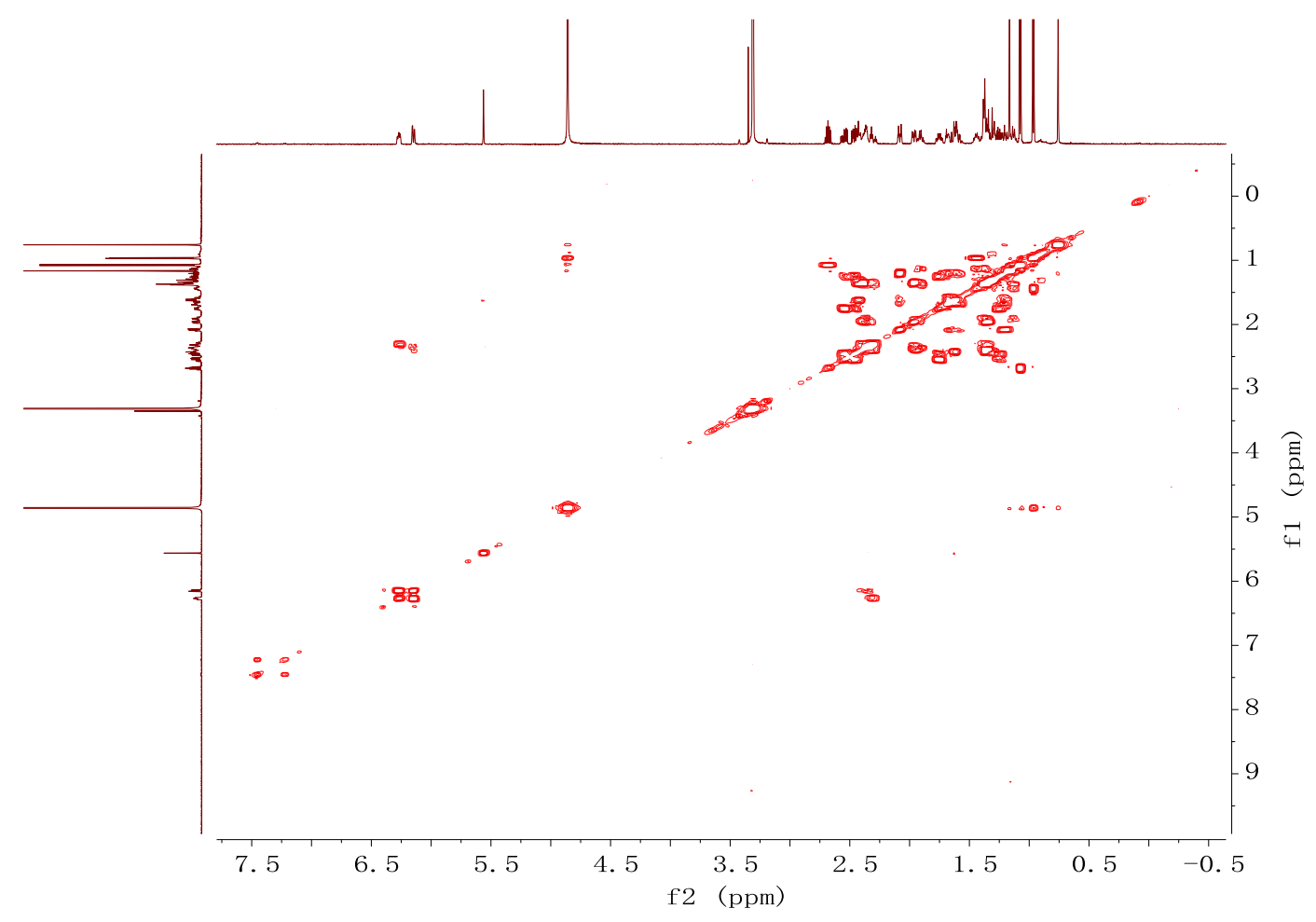

Figure S36. ${ }^{1} \mathrm{H}-{ }^{1} \mathrm{H}$ COSY $(600 \mathrm{MHz})$ spectrum of 5 in methanol- $d_{4}$. 


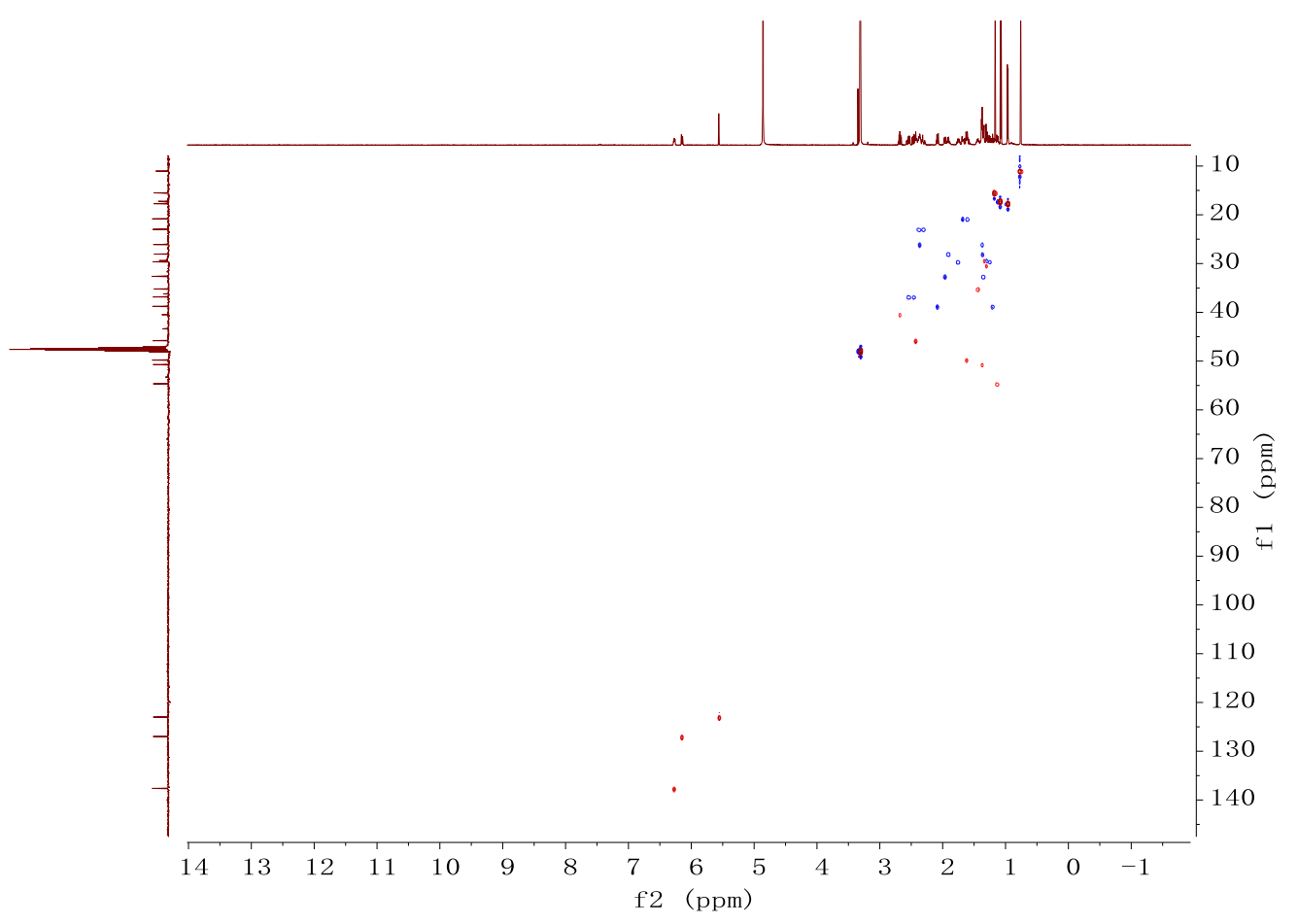

Figure S37. HSQC $(600 \mathrm{MHz})$ spectrum of 5 in methanol- $d_{4}$.

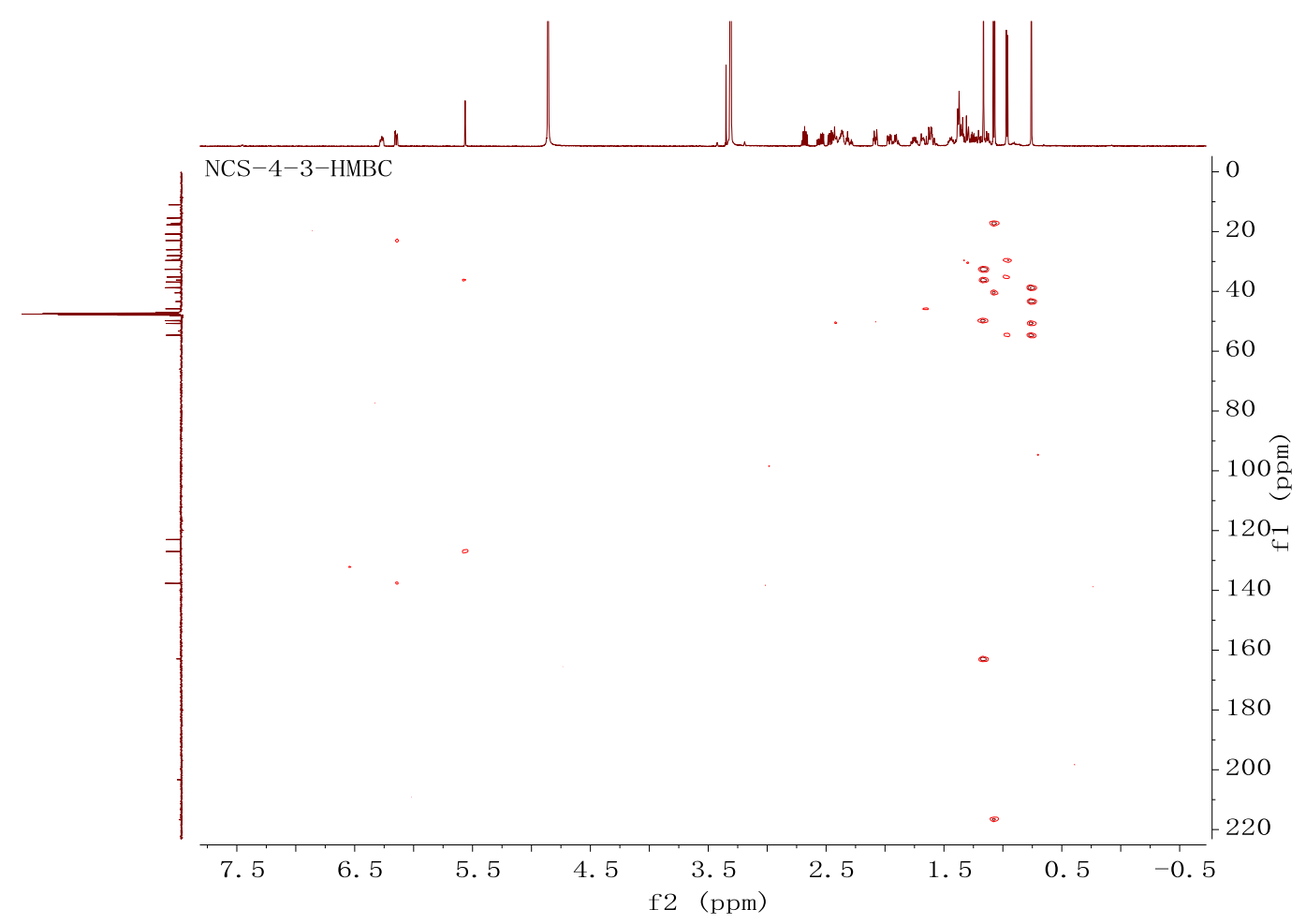

Figure S38. HMBC $(600 \mathrm{MHz})$ spectrum of 5 in methanol- $d_{4}$. 


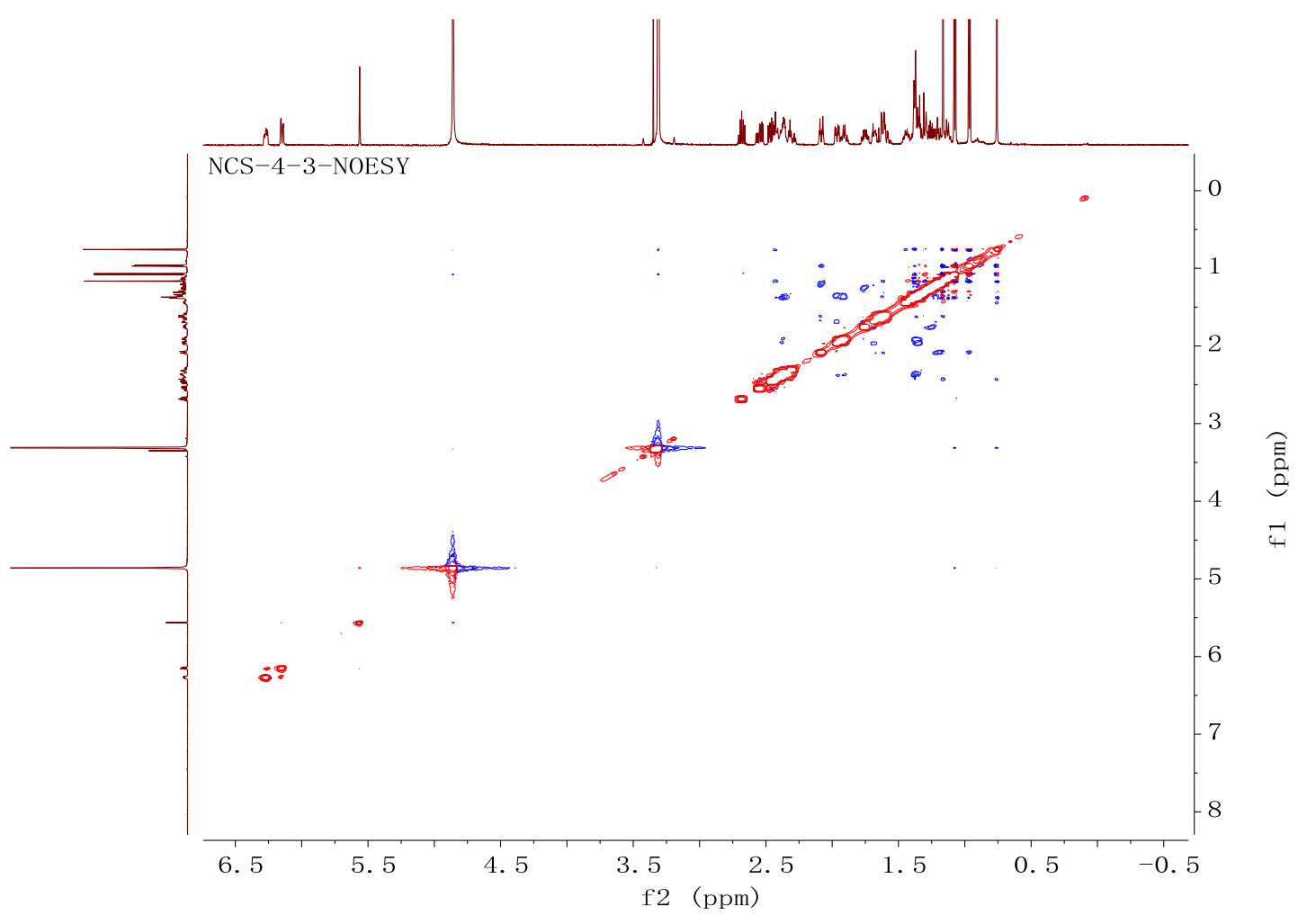

Figure S39. NOESY $(600 \mathrm{MHz})$ spectrum of 5 in methanol- $d_{4}$.
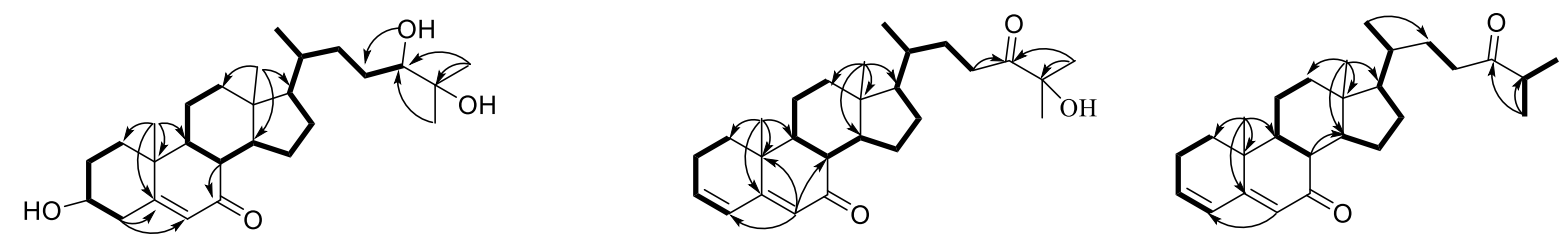

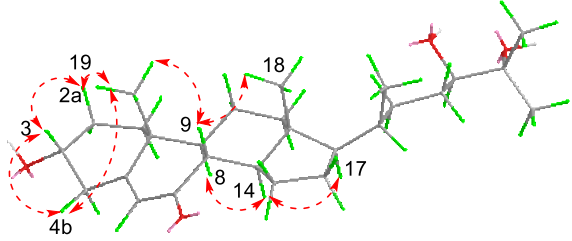

2

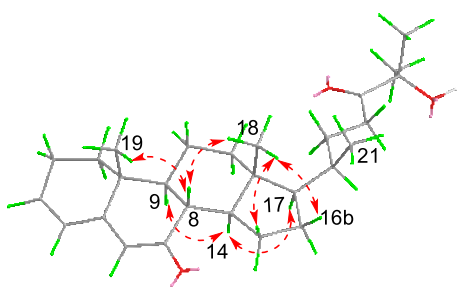

4

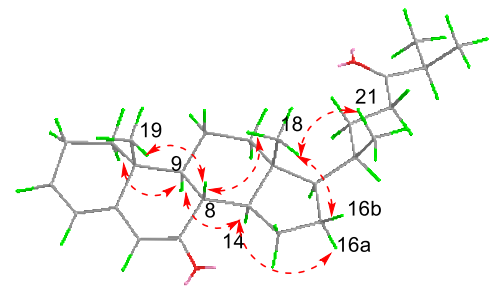

5

Figure S40. Key $\operatorname{COSY}(-), \operatorname{HMBC}(\neg)$, and $\operatorname{NOESY}\left(r^{\vee}\right)$ correlations for compounds $\mathbf{2}, \mathbf{4}$ and $\mathbf{5}$. 

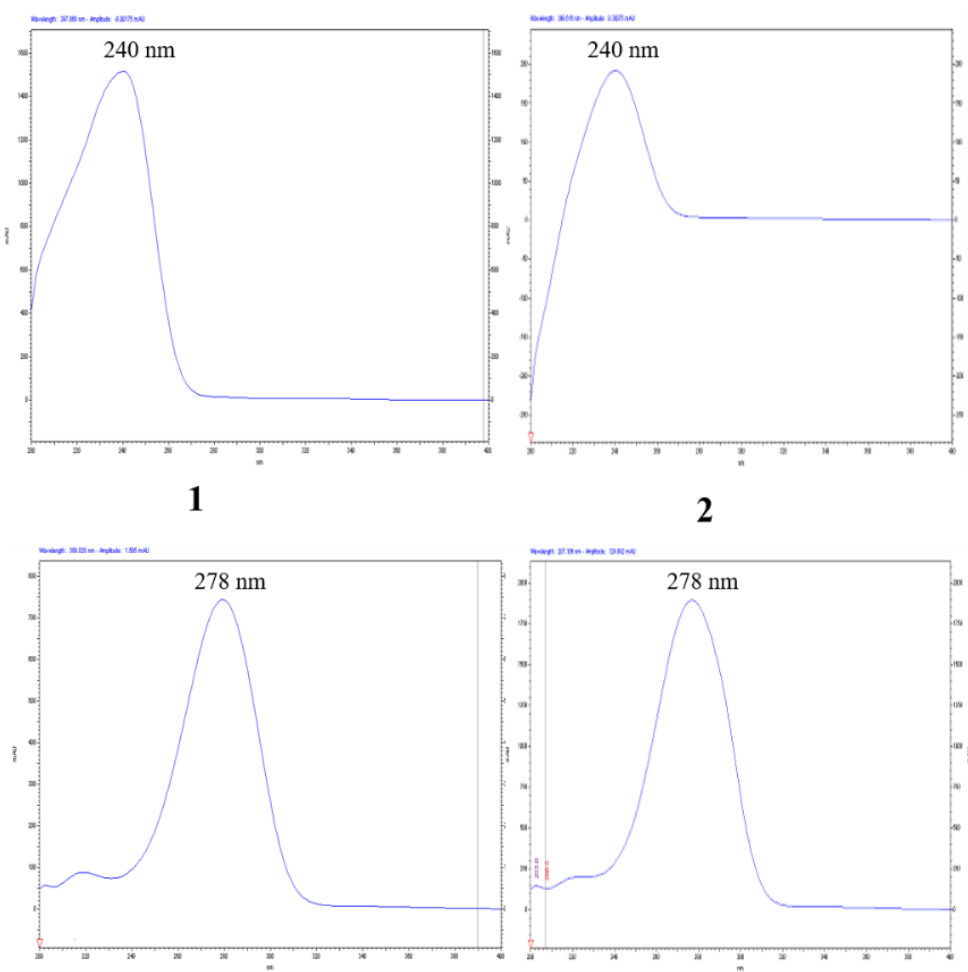

4

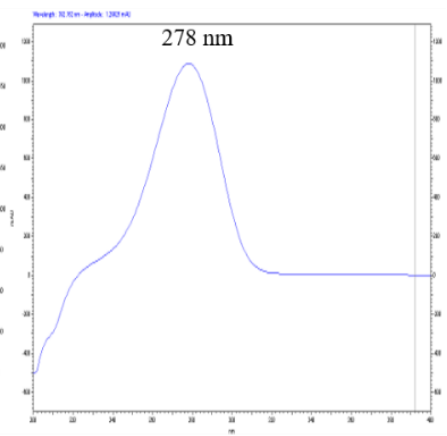

5

Figure S41. UV spectra of $\mathbf{1 5}$.

C44

$\mathrm{CE}=6$

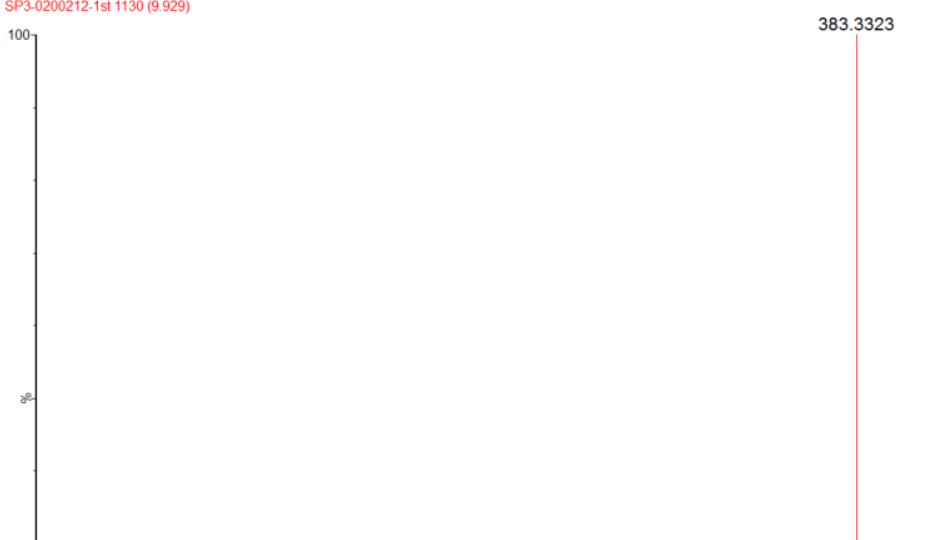

384.3345

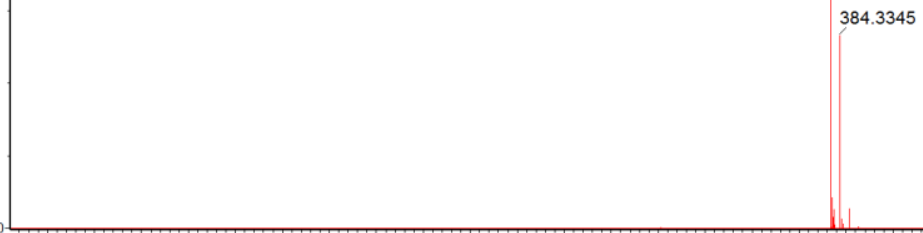

Figure S42. (+)-HRESIMS of 6. 


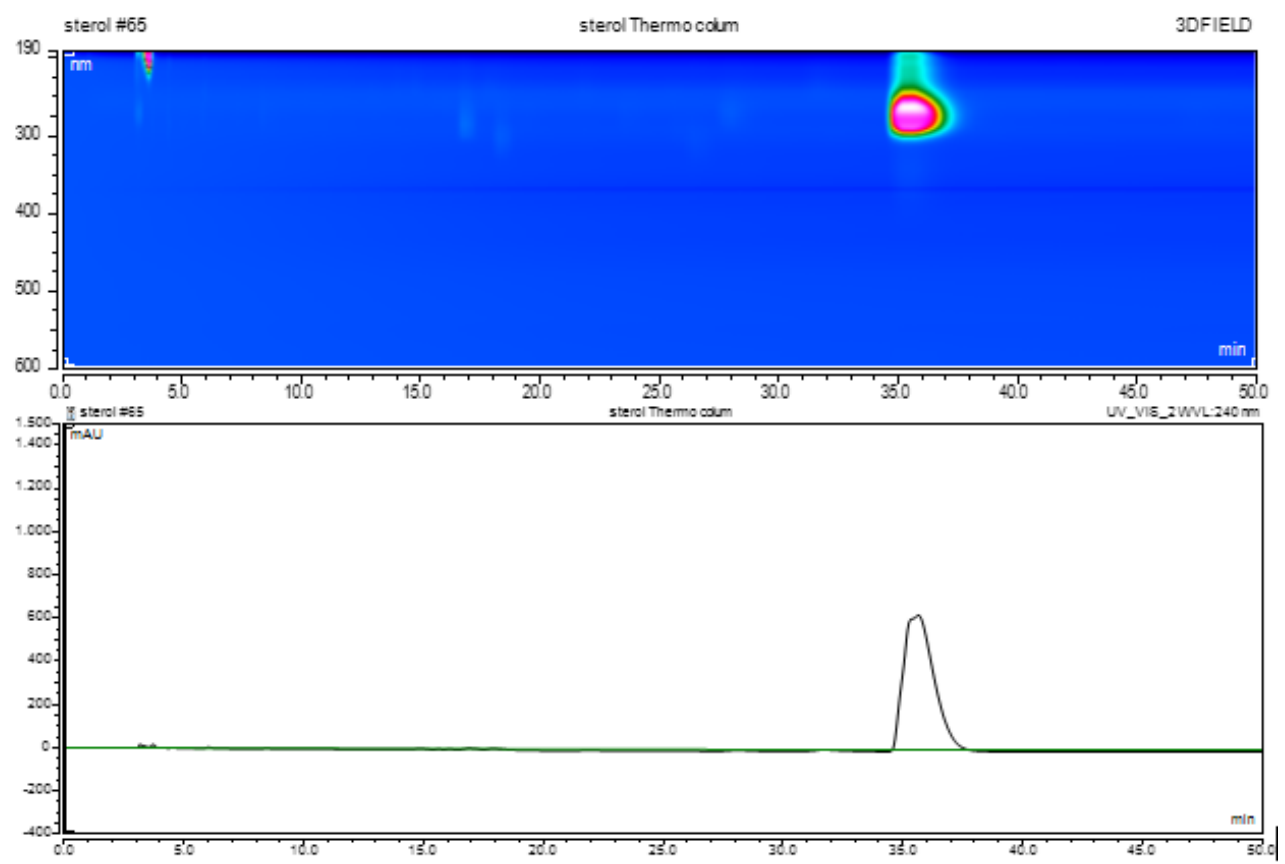

Figure S43. Purity of compound 6 by HPLC.

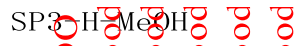

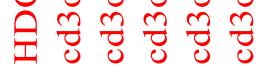

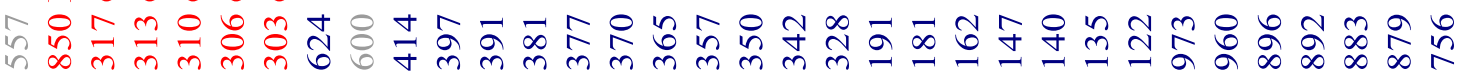

n

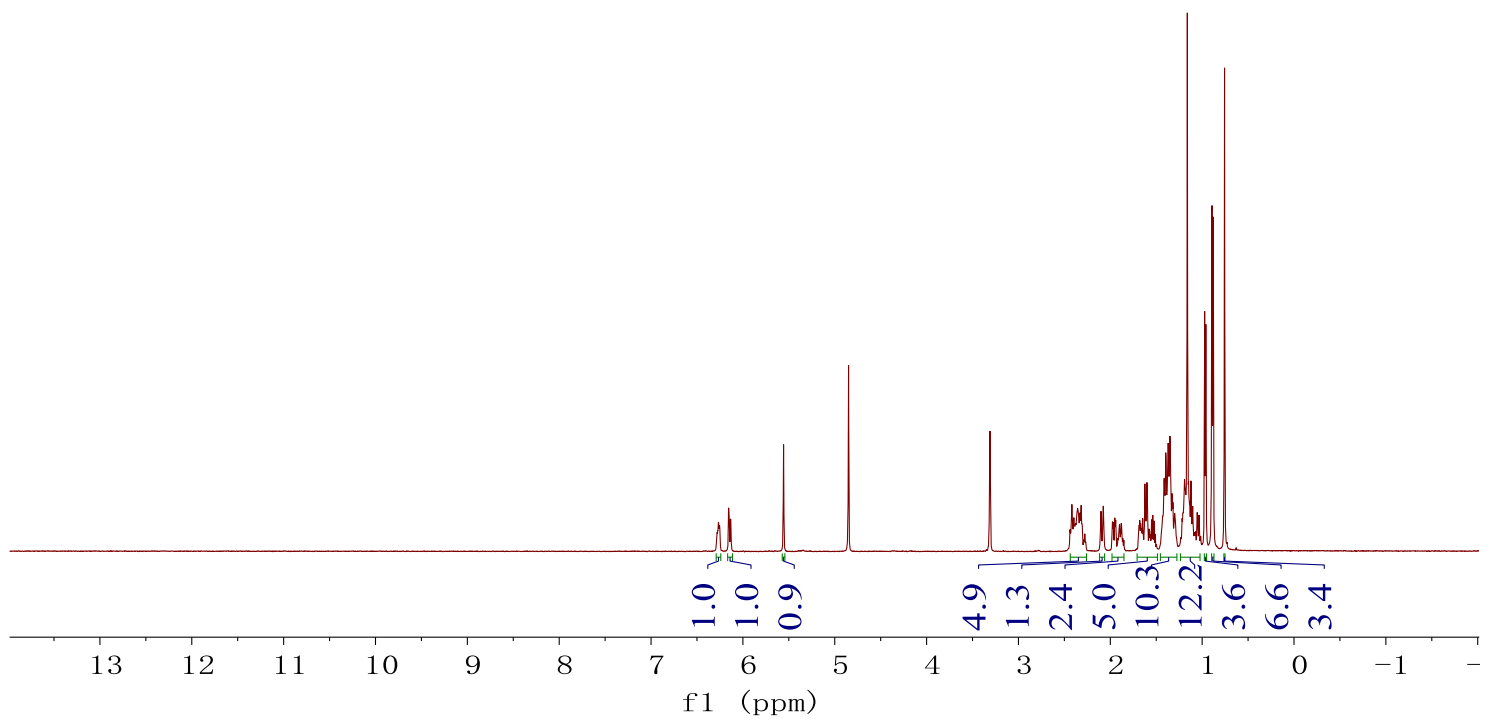

Figure S44. ${ }^{1} \mathrm{H}-\mathrm{NMR}(500 \mathrm{MHz})$ spectrum of 6 in methanol- $d_{4}$. 

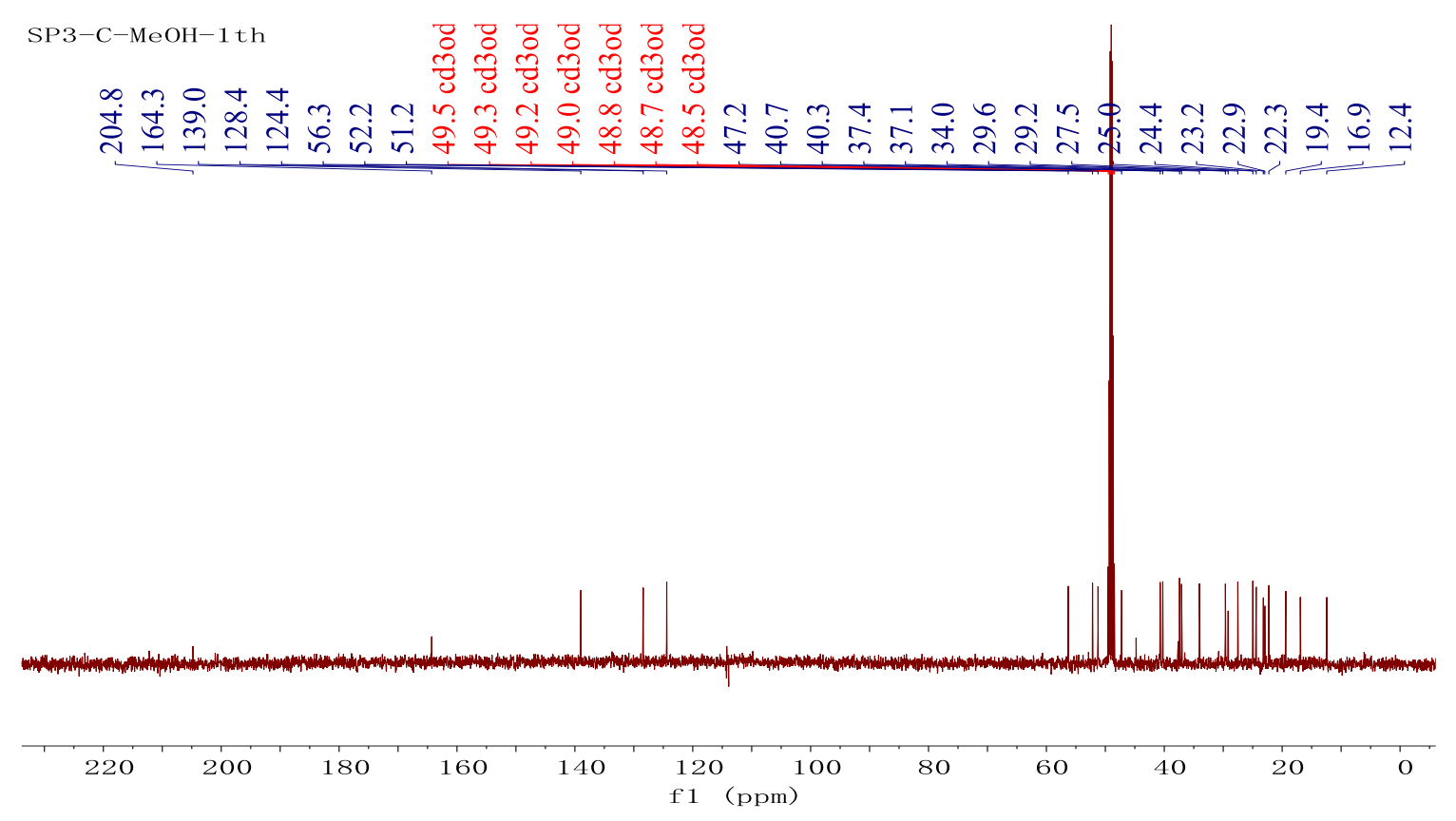

Figure S45. ${ }^{13} \mathrm{C}-\mathrm{NMR}(125 \mathrm{MHz})$ spectrum of 6 in methanol- $d_{4}$.

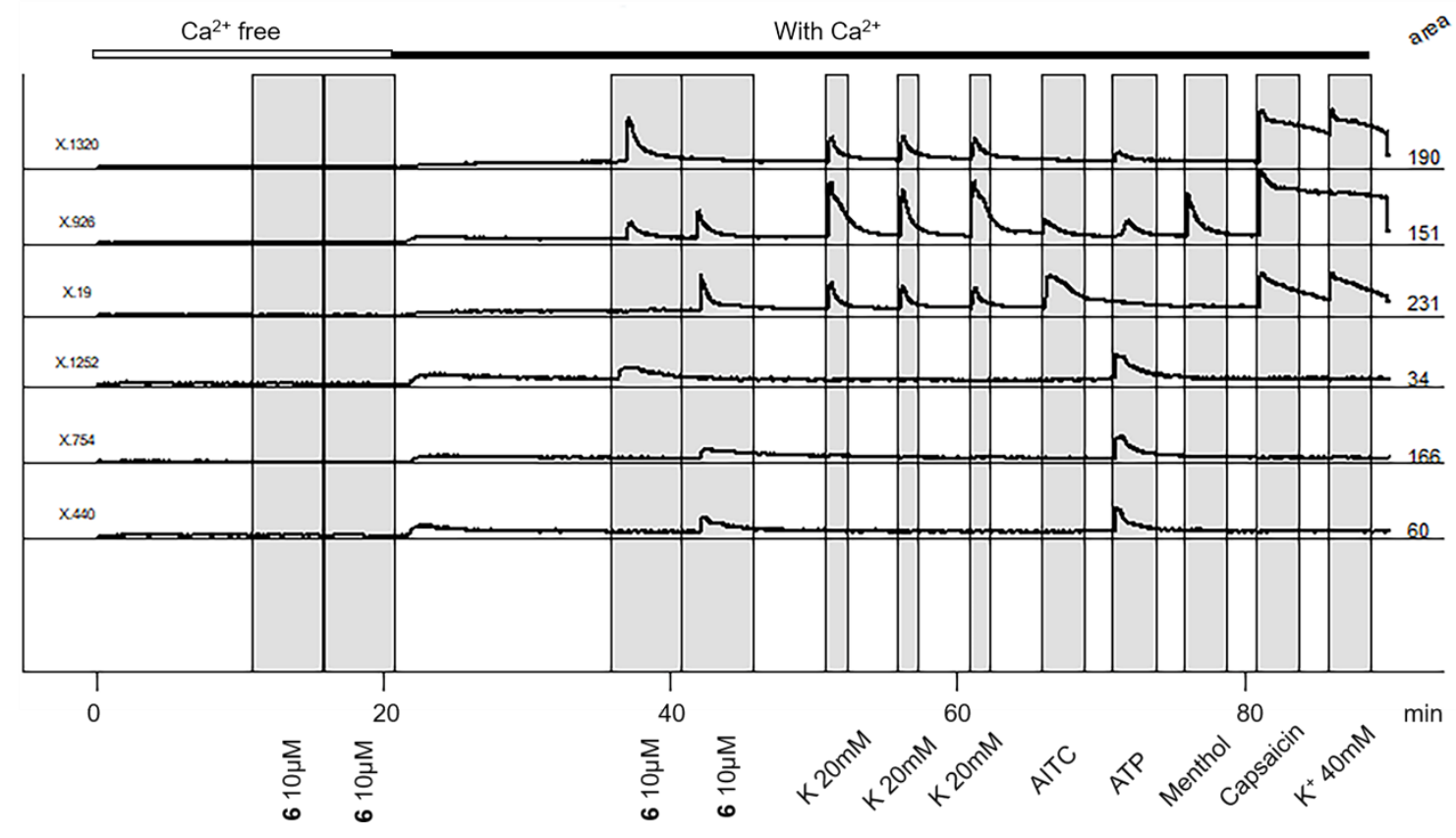

Figure S46. Compound 6 increases the cytoplasmic $\left[\mathrm{Ca}^{2+}\right]$ from the extracellular DRG observation solution not from the intracellular $\left[\mathrm{Ca}^{2+}\right]$ store. 


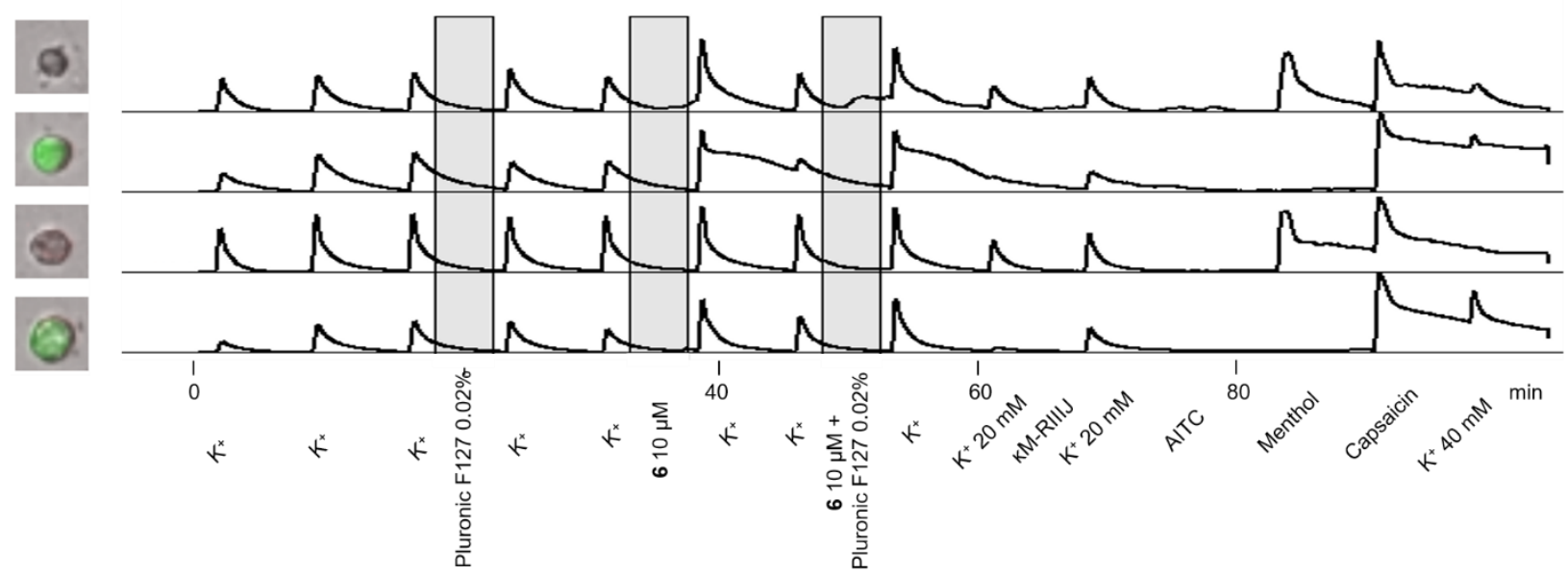

Figure S47. DRG activity of $6(10 \mu \mathrm{M})$ with or without detergent Pluronic F127 (0.02\%)

\section{g.names1 $n=2$}

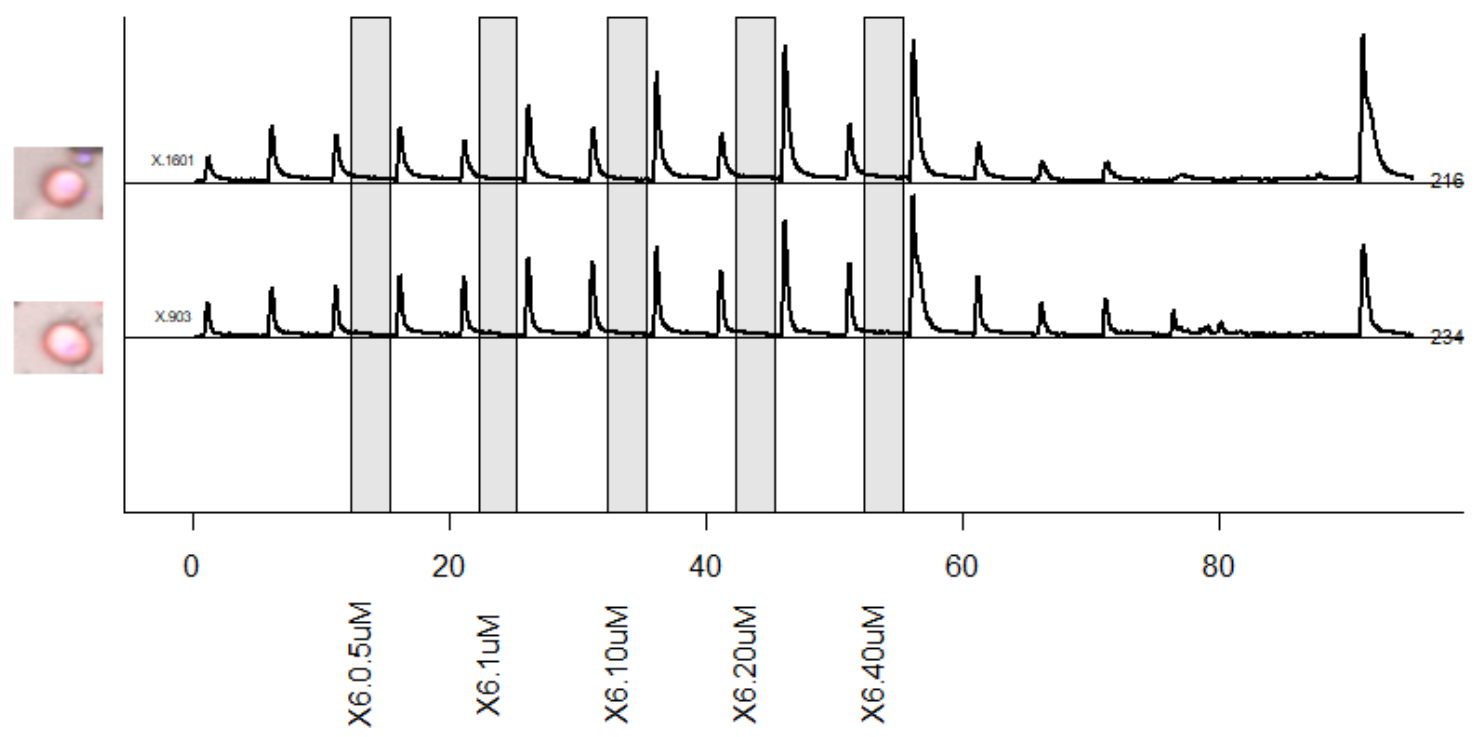

RD.20201021.23FN.m3.p3

Figure S48. Dose response of $6(0.5,1,10,20$ and $40 \mu \mathrm{M})$ to $\mathrm{KCl}(30 \mathrm{mM})$ in DRG assay. 


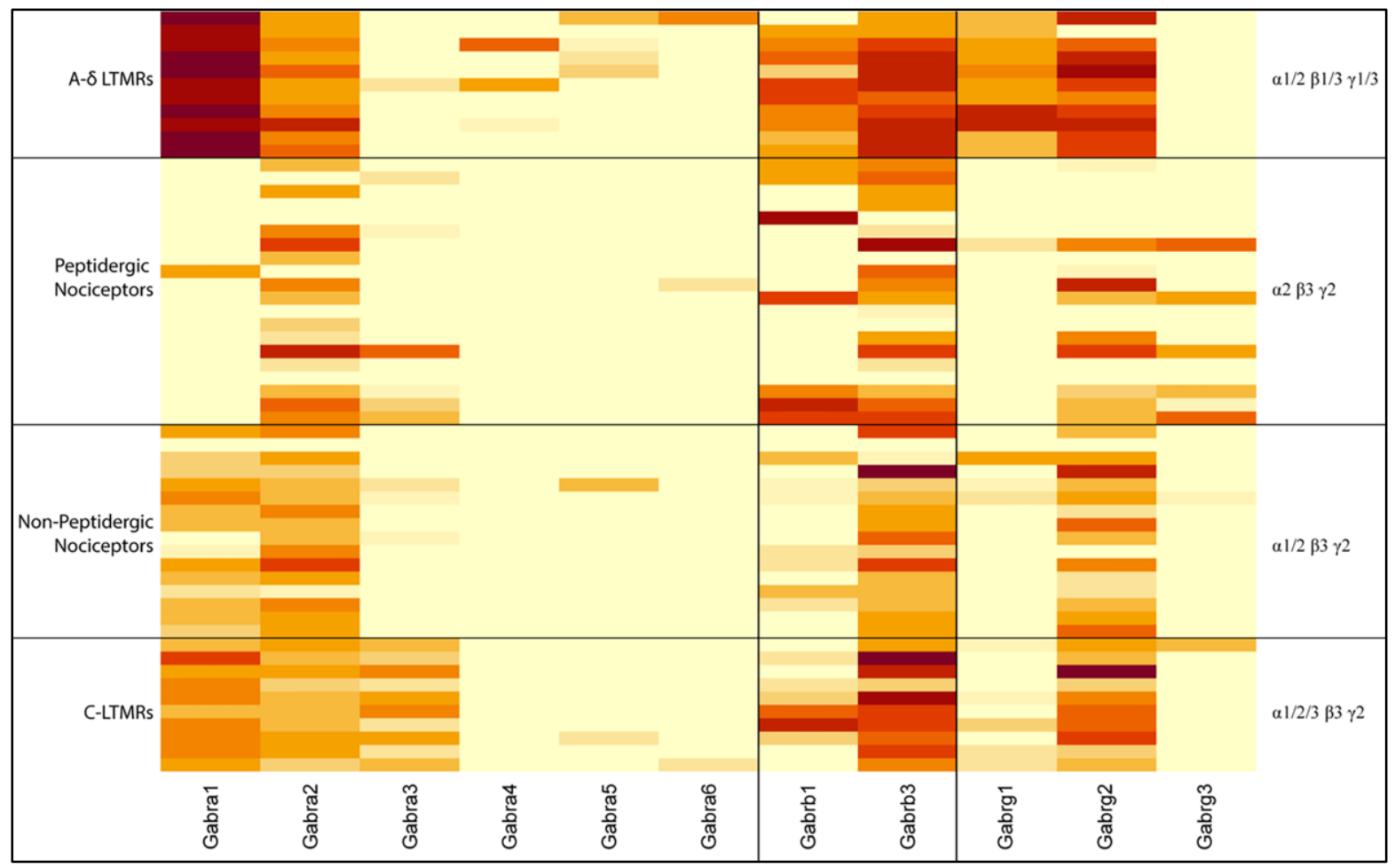

Figure S49. Single-cell transcriptomic GABA receptor gene expression in mouse cell-type specific DRG cells. The heatmap is a representation of the single cell transcriptomic data where each row is an individual cell, and each column is a gene. The heatmap is color-coated based on the level of expression on a logarithmic scale. Darker red colors represent high expression, lighter colors represent lower expression. Cell types are indicated on the left. $\mathrm{GABA}_{\mathrm{A}}$ receptor subunits are indicated on the right. 


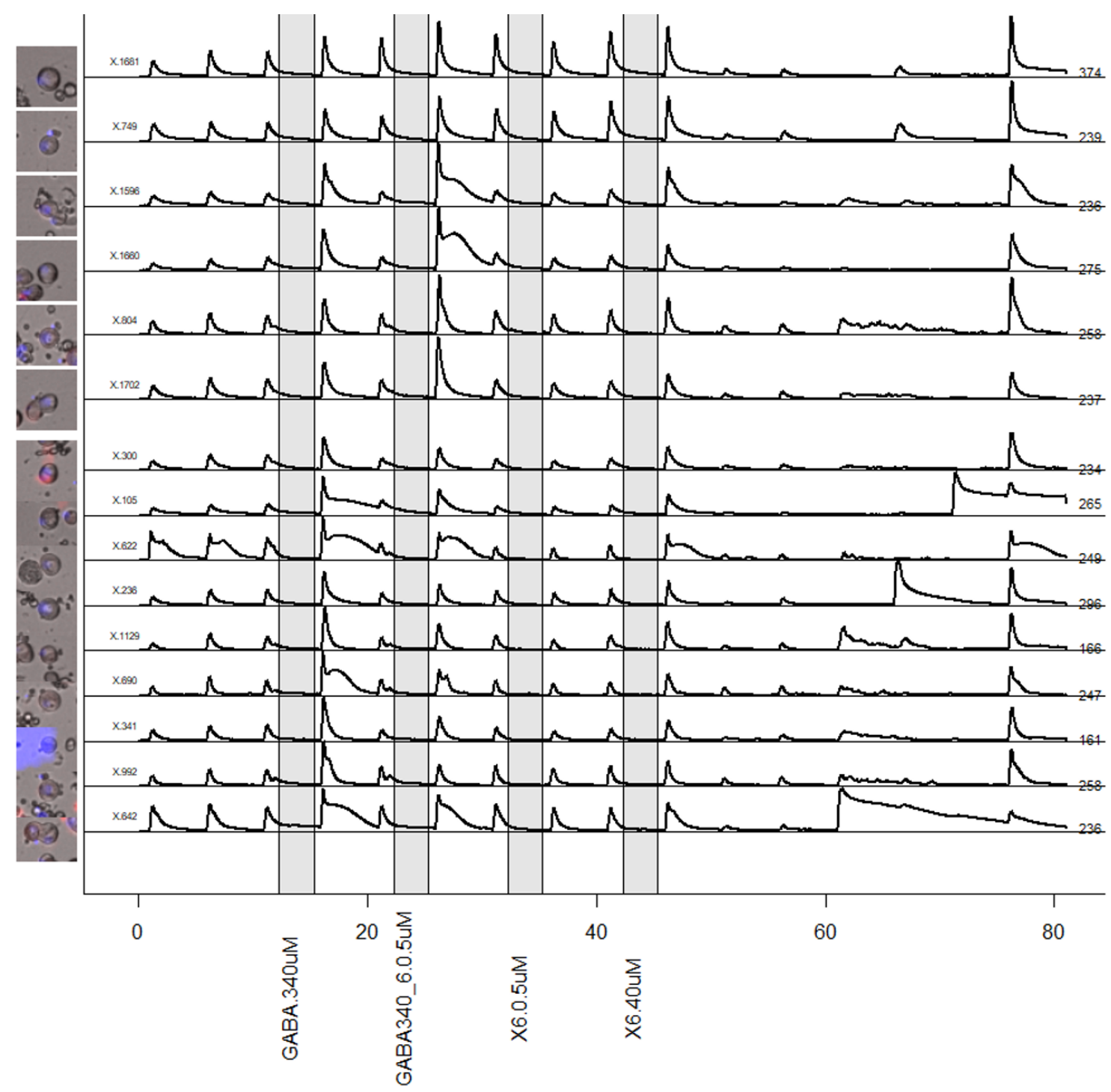

RD.20201009.42m.gfpn.m3.p2

Figure S50. Constellation pharmacology of $6(0.5 \mu \mathrm{M})$ in presence of GABA $(340 \mu \mathrm{M})$. In intervals of five minutes, $\mathrm{KCl}(30 \mathrm{mM})$ was applied for $10 \mathrm{~s}$ to depolarize the neurons. Cells were incubated for 4 min with GABA $(340 \mu \mathrm{M})$, GABA $(340 \mu \mathrm{M})+6(0.5 \mu \mathrm{M})$, GABA $(340 \mu \mathrm{M}), \mathbf{6}(0.5 \mu \mathrm{M})$, and $6(40 \mu \mathrm{M})$, at times 12, 22, 32, and 42 min, respectively. This experiment uesd a 42 day-old male mouse with 1700 DRG cells. 


\section{ELEVATED PLUS MAZE TEST}
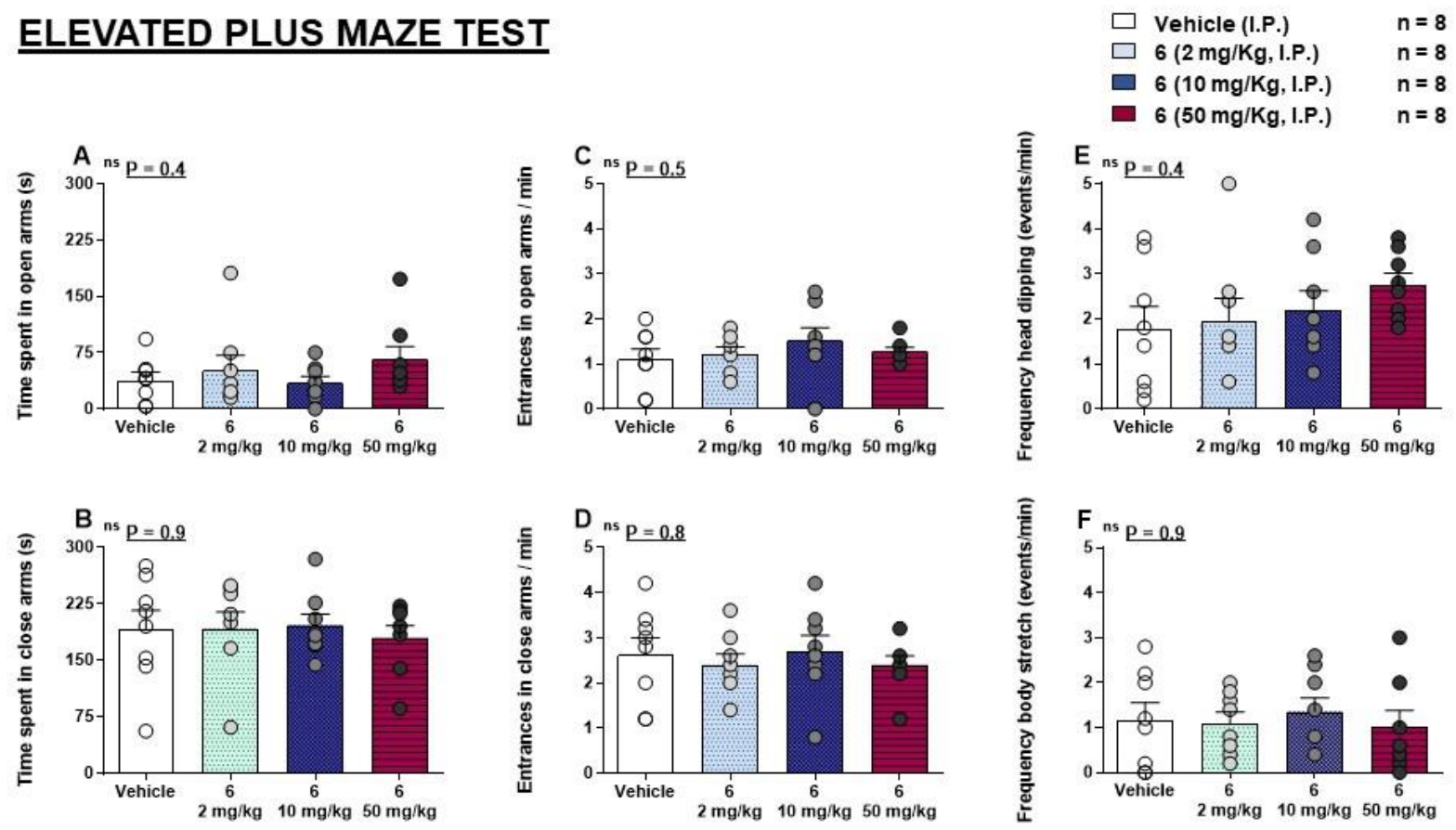

Figure S51. Effects of 6 (2, 10, $50 \mathrm{mg} / \mathrm{kg}$, I.P.) on Elevated Plus Maze (EPM) model. 


\section{OPEN FIELD TEST}
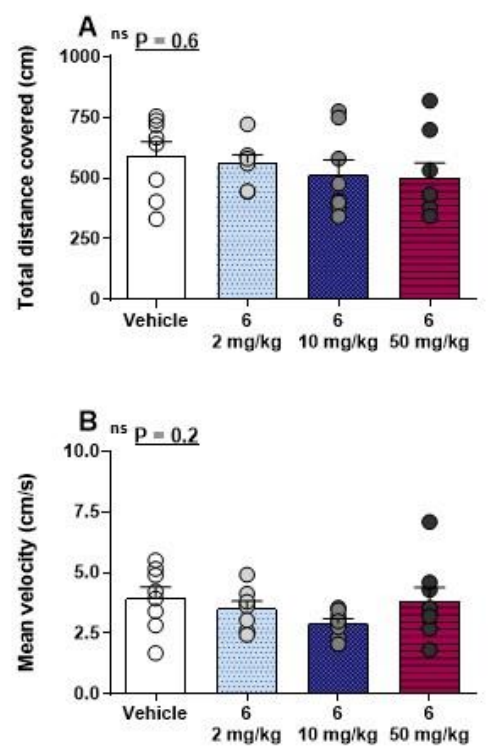
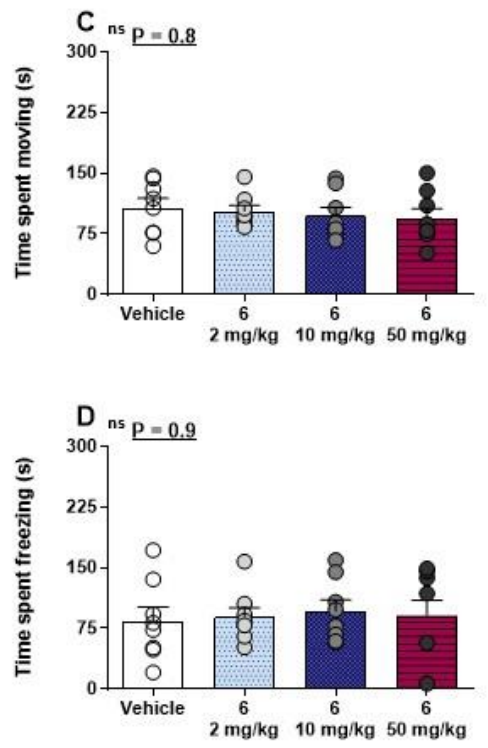
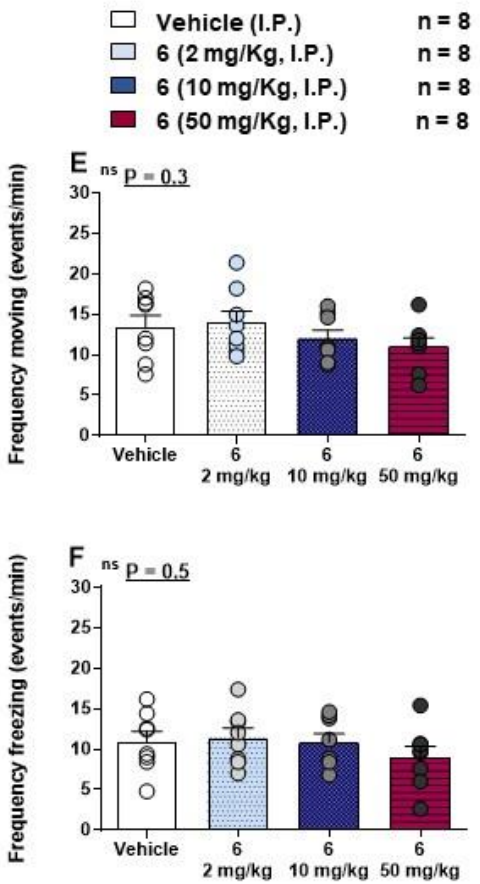

Figure S52. Effects of 6 (2, 10, $50 \mathrm{mg} / \mathrm{kg}$, I.P.) on Open Field (OF) test. 


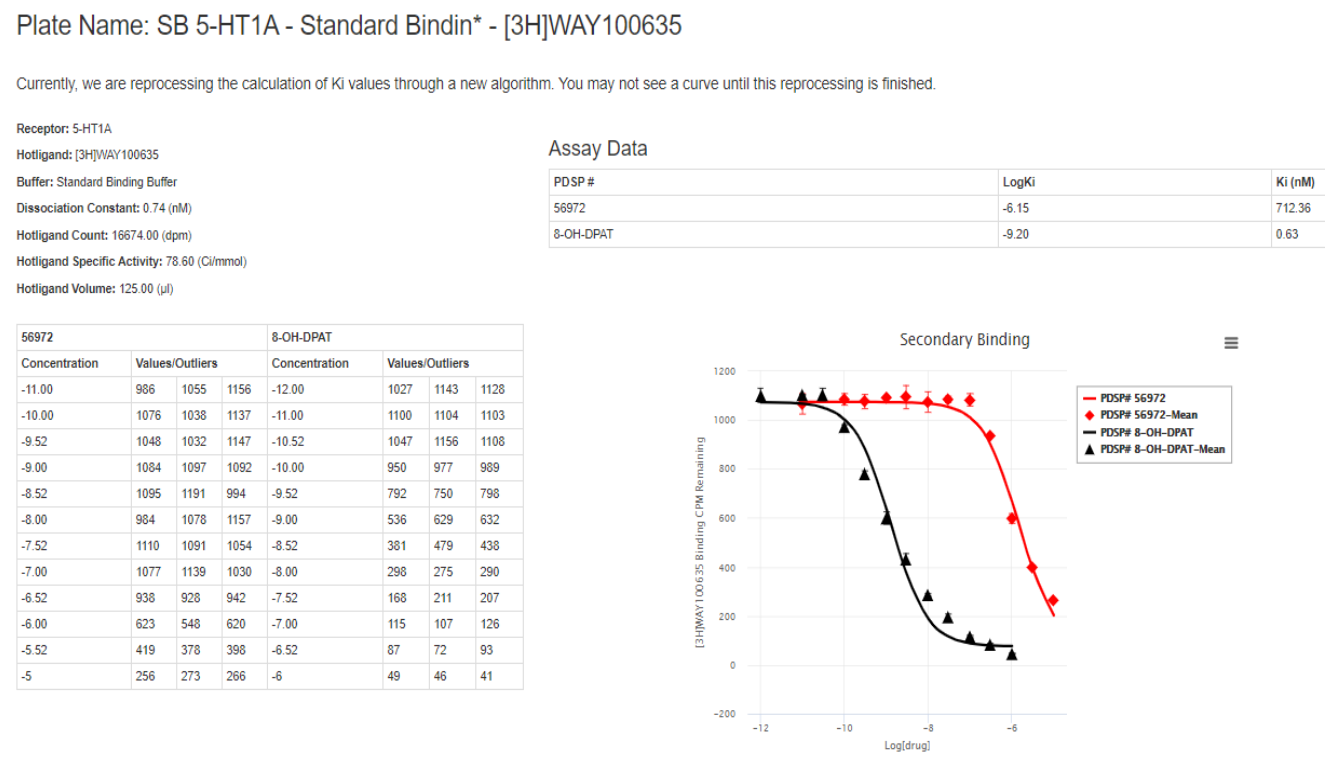

Figure S53. 5-HT1A receptor binding assay of compound 6.

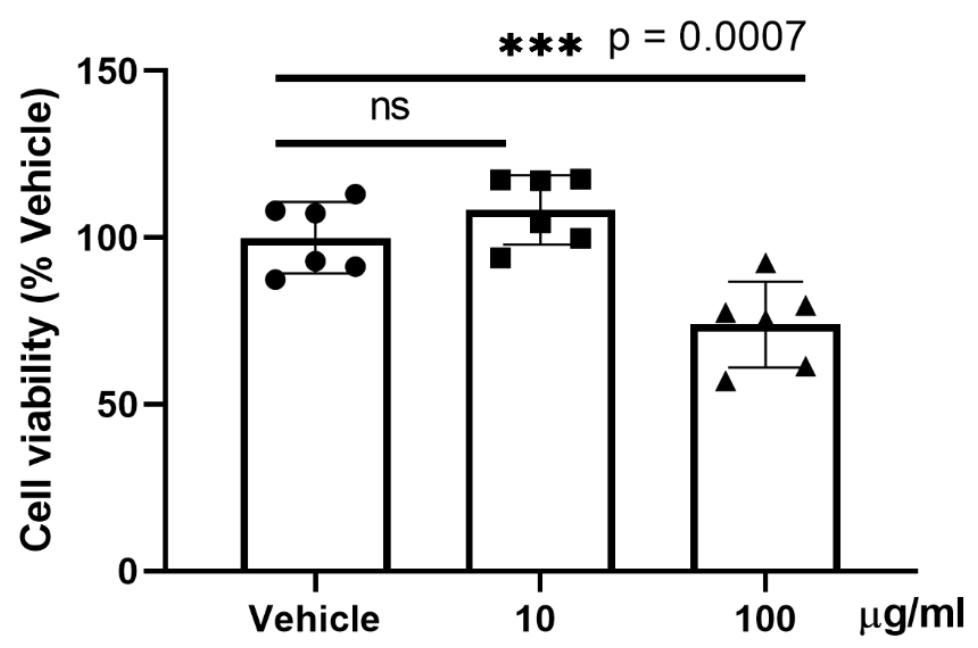

Figure S54. 24 hours cytotoxicity test of the crude extract of hypobranchial gland of C. geographus (10 and 100 $\mu \mathrm{g} / \mathrm{ml}$ ) in human HEK 293 cell line. 


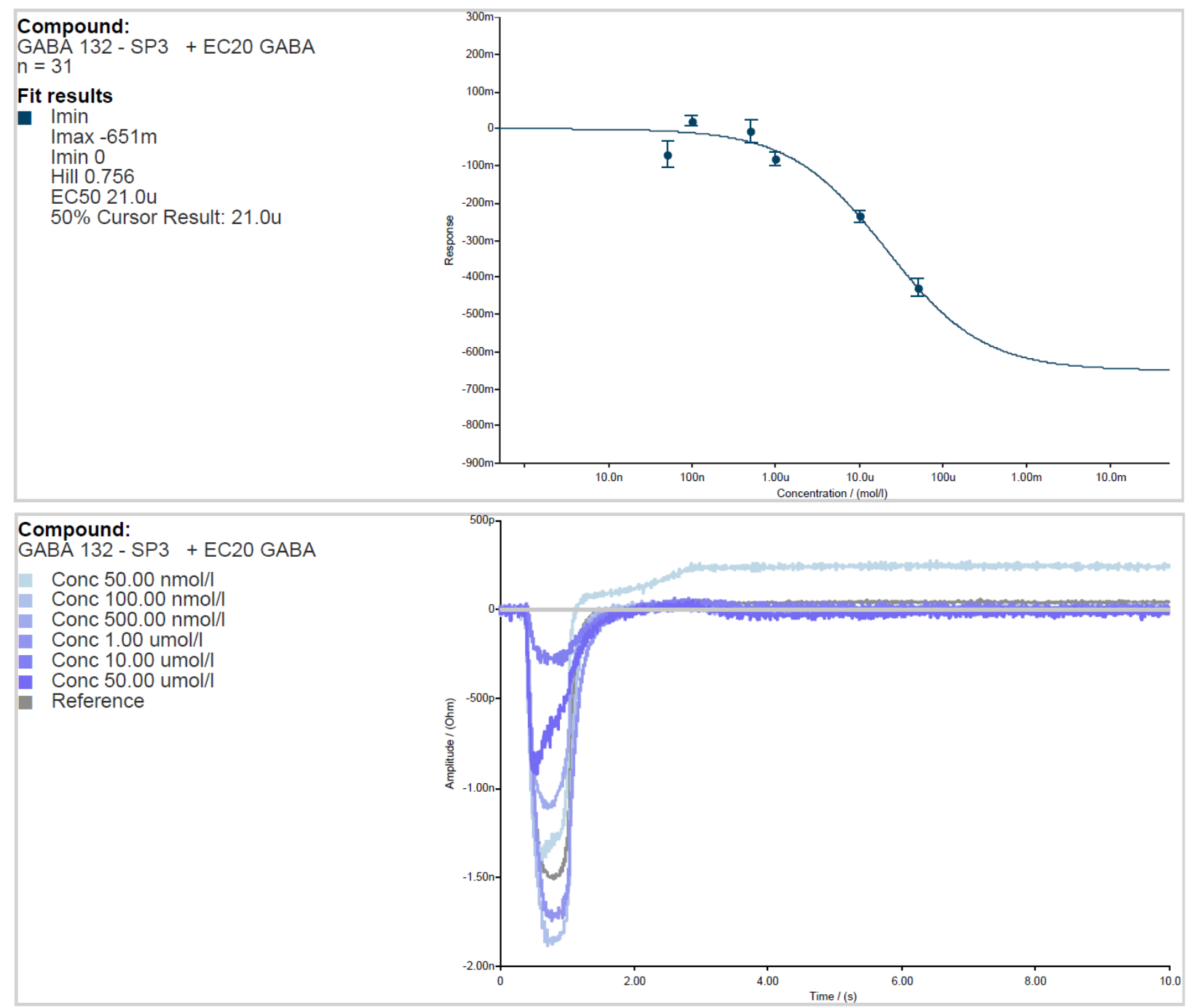

Figure S55. Selected $\mathrm{GABA}_{A} \mathrm{R}(\alpha 1 \beta 3 \gamma 2)$ responses to $\mathrm{GABA} \mathrm{EC}_{20}$ in the absence and presence of 6 . Blue traces are $\mathrm{GABA}_{A} \mathrm{R}(\alpha 1 \beta 3 \gamma 2)$ responses to $\mathrm{GABA} \mathrm{EC}_{20}$ in the presence of $\mathbf{6}$ at different concentrations, and the grey trace is the response to $\mathrm{GABA} \mathrm{EC}_{20}$ alone. 
Table S1. ${ }^{1} \mathrm{H}$ NMR $(600 \mathrm{MHz})$ and ${ }^{13} \mathrm{C}$ NMR ( $a: 125 \mathrm{MHz}$ and $\left.b: 150 \mathrm{MHz}\right)$ data of compounds $\mathbf{1}-\mathbf{5}(\delta$ in ppm, $J$ in $\mathrm{Hz}$ ) in methanol- $d_{4}$.

\begin{tabular}{|c|c|c|c|c|c|c|c|c|c|c|}
\hline \multirow[t]{2}{*}{ No. } & \multicolumn{2}{|l|}{1} & \multicolumn{2}{|l|}{2} & \multicolumn{2}{|l|}{3} & \multicolumn{2}{|l|}{4} & \multicolumn{2}{|l|}{5} \\
\hline & $\delta_{\mathrm{H}}(J, \mathrm{~Hz})$ & $\delta_{\mathrm{C}^{a}}$ & $\delta_{\mathrm{H}}(J, \mathrm{~Hz})$ & $\delta_{\mathrm{C}^{b}}^{b}$ & $\delta_{\mathrm{H}}(J, \mathrm{~Hz})$ & $\delta_{\mathrm{C}}^{b}$ & $\delta_{\mathrm{H}}(J, \mathrm{~Hz})$ & $\delta_{\mathrm{C}^{b}}$ & $\delta_{\mathrm{H}}(J, \mathrm{~Hz})$ & $\delta_{\mathrm{C}^{b}}$ \\
\hline 1 & $\begin{array}{l}\text { a } 2.00, \mathrm{dt}, 13.8,3.6 \\
\text { b } 1.25 \text {, overlap }\end{array}$ & 37.6 & $\begin{array}{l}\text { a } 2.03, \mathrm{dt}, 13.8,3.6 \\
\text { b } 1.25, \text { overlap }\end{array}$ & 37.2 & $\begin{array}{l}\text { a } 1.97, \mathrm{dd}, 13.2,5.4 \\
\text { b } 1.34, \mathrm{dd}, 13.2,5.4\end{array}$ & 34.0 & $\begin{array}{l}\text { a } 1.96, \mathrm{dd}, 13.2, \\
4.8 \\
\text { b } 1.34, \mathrm{dd}, 12.6, \\
6.0\end{array}$ & 33.9 & $\begin{array}{l}\text { a } 1.96,13.2,4.2 \\
\text { b } 1.34 \text {, overlap }\end{array}$ & 34.0 \\
\hline 2 & $\begin{array}{l}\text { a } 1.90, \mathrm{~m} \\
\text { b } 1.60, \mathrm{~m}\end{array}$ & 31.9 & $\begin{array}{l}\text { a } 2.16, \mathrm{dt}, 12.6,2.4 \\
\text { b } 1.76, \mathrm{~m}\end{array}$ & 29.5 & $\begin{array}{l}\text { a } 2.39, \mathrm{~m} \\
\text { b } 2.30, \mathrm{dt}, 13.8,6.0\end{array}$ & 24.3 & $\begin{array}{l}\text { a } 2.39, \text { overlap } \\
\text { b } 2.30, \mathrm{dt}, 19.8, \\
5.4\end{array}$ & 24.3 & $\begin{array}{l}\text { a } 2.37 \text {, overlap } \\
\text { b } 2.30, \mathrm{dt}, 18.6,5.4\end{array}$ & 24.4 \\
\hline 3 & $3.56, \mathrm{~m}$ & 71.2 & $4.26, \mathrm{~m}$ & 77.8 & $\begin{array}{l}6.28 \text {, ddd, 9.0, 5.4, } \\
2.4\end{array}$ & 139.0 & $\begin{array}{l}6.27 \text {, ddd, 9.6, 5.4, } \\
1.8\end{array}$ & 139.0 & 6.28 , ddd, $9.0,5.4,2.4$ & 139.0 \\
\hline 4 & $\begin{array}{l}\text { a } 2.48, \text { ddd, } 14.4,4.8 \text {, } \\
1.8 \\
\text { b } 2.41, \mathrm{dd}, 11.4,1.8\end{array}$ & 42.7 & $\begin{array}{l}\text { a } 2.79, \text { ddd, } 14.4,4.8, \\
1.8 \\
\text { b } 2.56 \text {, ddd, 14.4,12.6, } \\
1.8\end{array}$ & 40.0 & $6.15, \mathrm{dd}, 10.2,3.0$ & 128.4 & $6.15, \mathrm{dd}, 10.2,2.4$ & 128.4 & $6.15, \mathrm{dd}, 10.2,3.0$ & 128.4 \\
\hline 5 & & 169.1 & & 168.1 & & 164.3 & & 164.3 & & 164.3 \\
\hline 6 & $5.66, \mathrm{~d}, 1.2$ & 126.3 & $5.69, \mathrm{~d}, 1.2$ & 126.6 & $5.56, \mathrm{~s}$ & 124.4 & $5.56, \mathrm{~s}$ & 124.4 & $5.56, \mathrm{~s}$ & 124.4 \\
\hline 7 & & 204.7 & & 204.5 & & 204.6 & & 204.7 & & 204.7 \\
\hline 8 & $2.32, \mathrm{dd}, 12.6,10.8$ & 46.6 & $2.32, \mathrm{dd}, 12.6,10.8$ & 46.5 & $2.43, \mathrm{t}, 10.2$ & 47.2 & $2.43, \mathrm{~m}$ & 47.2 & $2.43, \mathrm{~m}$ & 47.2 \\
\hline 9 & $1.51, \mathrm{~m}$ & 51.5 & $1.53, \mathrm{~m}$ & 51.2 & 1.62 , overlap & 51.2 & 1.62 , overlap & 51.1 & 1.62 , overlap & 51.2 \\
\hline 10 & & 40.1 & & 39.6 & & 37.7 & & 37.6 & & 37.6 \\
\hline 11 & $\begin{array}{l}\text { a } 1.65, \mathrm{~m} \\
\text { b } 1.63, \mathrm{~m}\end{array}$ & 22.3 & $\begin{array}{l}\text { a } 1.65, \mathrm{~m} \\
\text { b } 1.63, \mathrm{~m}\end{array}$ & 22.2 & $\begin{array}{l}\text { a } 1.69, \mathrm{~m} \\
\text { b } 1.60, \text { overlap }\end{array}$ & 22.1 & $\begin{array}{l}\text { a } 1.68, \mathrm{~m} \\
\text { b } 1.60, \text { overlap }\end{array}$ & 22.2 & $\begin{array}{l}\text { a } 1.68, \mathrm{~m} \\
\text { b } 1.60, \text { overlap }\end{array}$ & 22.2 \\
\hline 12 & $\begin{array}{l}\text { a } 2.08 \text {. dt, } 13.2,3.6 \\
\text { b } 1.17 \text {, overlap }\end{array}$ & 40.1 & $\begin{array}{l}\text { a } 2.08 \text {. dt, } 13.2,3.6 \\
\text { b } 1.17 \text {, overlap }\end{array}$ & 40.0 & $\begin{array}{l}\text { a } 2.10, \mathrm{dt}, 12.6,3.0 \\
\text { b } 1.20, \mathrm{~m}\end{array}$ & 40.1 & $\begin{array}{l}\text { a } 2.09, \mathrm{dt}, 13.2, \\
3.6 \\
\text { b } 1.21, \mathrm{dt}, 13.2, \\
4.8\end{array}$ & 40.1 & $\begin{array}{l}\text { a } 2.08, \mathrm{dt}, 12.6,3.6 \\
\text { b } 1.20, \mathrm{~m}\end{array}$ & 40.2 \\
\hline 13 & & 44.3 & & 44.3 & & 44.8 & & 44.8 & & 44.8 \\
\hline 14 & $1.32, \mathrm{~m}$ & 51.5 & $1.32, \mathrm{~m}$ & 51.4 & 1.37 , overlap & 52.1 & 1.38 , overlap & 52.1 & 1.37 , overlap & 52.1 \\
\hline 15 & $\begin{array}{l}\text { a } 1.94, \mathrm{~m} \\
\text { b } 1.37, \mathrm{dt}, 11.4,3.0\end{array}$ & 29.5 & $\begin{array}{l}\text { a } 1.94, \mathrm{~m} \\
\text { b } 1.37, \mathrm{~m}\end{array}$ & 29.5 & $\begin{array}{l}\text { a } 2.35, \mathrm{~m} \\
\text { b } 1.39, \mathrm{~m}\end{array}$ & 27.5 & $\begin{array}{l}\text { a } 2.36 \text {, overlap } \\
\text { b } 1.38 \text {, overlap }\end{array}$ & 27.4 & $\begin{array}{l}\text { a } 2.36 \text {, overlap } \\
\text { b } 1.39 \text {, overlap }\end{array}$ & 27.5 \\
\hline 16 & $\begin{array}{l}\text { a } 2.38, \mathrm{~m} \\
\text { b } 1.27, \mathrm{~m}\end{array}$ & 27.4 & $\begin{array}{l}\text { a } 2.38, \mathrm{~m} \\
\text { b } 1.27, \mathrm{~m}\end{array}$ & 27.3 & $\begin{array}{l}\text { a } 1.94, \mathrm{~m} \\
\text { b } 1.38, \text { overlap }\end{array}$ & 29.4 & $\begin{array}{l}\text { a } 1.91, \mathrm{~m} \\
\text { b } 1.38 \text {, overlap }\end{array}$ & 29.4 & $\begin{array}{l}\text { a } 1.91, \mathrm{~m} \\
\text { b } 1.38, \text { overlap }\end{array}$ & 29.5 \\
\hline 17 & 1.14 , overlap & 56.2 & 1.14 , overlap & 56.1 & 1.15 , overlap & 56.2 & 1.14 , overlap & 56.0 & 1.15 , overlap & 56.1 \\
\hline 18 & $0.74, \mathrm{~s}$ & 12.4 & $0.74, \mathrm{~s}$ & 12.4 & $0.77, \mathrm{~s}$ & 12.3 & $0.76, \mathrm{~s}$ & 12.3 & $0.76, \mathrm{~s}$ & 12.4 \\
\hline 19 & $1.24, \mathrm{~s}$ & 17.7 & $1.25, \mathrm{~s}$ & 17.6 & $1.17, \mathrm{~s}$ & 16.8 & $1.17, \mathrm{~s}$ & 16.8 & $1.17, \mathrm{~s}$ & 16.9 \\
\hline 20 & $1.46, \mathrm{~m}$ & 37.4 & $1.46, \mathrm{~m}$ & 37.3 & $1.47, \mathrm{~m}$ & 37.3 & $1.46, \mathrm{~m}$ & 36.5 & $1.44, \mathrm{~m}$ & 36.6 \\
\hline 21 & $0.99, \mathrm{~d}, 6.6$ & 19.5 & $0.99, \mathrm{~d}, 6.6$ & 19.5 & $0.99, \mathrm{~d}, 6.6$ & 19.4 & $0.97, \mathrm{~d}, 6.6$ & 19.1 & $0.97, \mathrm{~d}, 6.6$ & 19.1 \\
\hline 22 & $\begin{array}{l}\text { a } 1.82, \text { ddd, } 12.6,3.8 \text {, } \\
3,6 \\
\text { b } 1.03, \mathrm{~m}\end{array}$ & 34.7 & $\begin{array}{l}\text { a } 1.82, \text { ddd, } 12.6,3.8, \\
3,6 \\
\text { b } 1.03, \mathrm{~m}\end{array}$ & 34.7 & $\begin{array}{l}\text { a } 1.83, \mathrm{~m} \\
\text { b } 1.04, \mathrm{~m}\end{array}$ & 34.6 & $\begin{array}{l}\text { a } 1.76, \mathrm{~m} \\
\text { b } 1.26 \text {, overlap }\end{array}$ & 30.8 & $\begin{array}{l}\text { a } 1.75, \mathrm{~m} \\
\text { b } 1.25, \mathrm{~m}\end{array}$ & 30.8 \\
\hline 23 & $\begin{array}{l}\text { a } 1.73 \text {, ddd, } 12.6,4.2 \text {, } \\
1.8 \\
\text { b } 1.10, \mathrm{~m}\end{array}$ & 28.9 & $\begin{array}{l}\text { a } 1.73, \mathrm{~m} \\
\text { b } 1.10, \mathrm{~m}\end{array}$ & 28.9 & $\begin{array}{l}\text { a } 1.74, \text { ddd, } 12.6, \\
3.0,1.2 \\
\text { b } 1.10, \mathrm{~m}\end{array}$ & 25.7 & $\begin{array}{l}\text { a } 2.70, \mathrm{~m} \\
\text { b } 2.64, \mathrm{~m}\end{array}$ & 34.0 & $\begin{array}{l}\text { a } 2.55 \text {, ddd, } 16.8,9.6 \text {, } \\
4.8 \\
\text { b } 2.46, \text { ddd, } 16.8,9.6 \\
6.6\end{array}$ & 34.0 \\
\hline 24 & 3.16 , dd, $10.2,1.2$ & 80.6 & 3.16 , dd, $10.2,1.2$ & 80.5 & 3.16 , dd, $10.2,1.8$ & 80.6 & & 217.7 & & 218.1 \\
\hline 25 & & 73.9 & & 73.8 & & 73.6 & & 77.9 & $2.68, \mathrm{~m}$ & 41.9 \\
\hline 26 & $1.13, \mathrm{~s}$ & 24.7 & $1.13, \mathrm{~s}$ & 24.7 & $1.13, \mathrm{~s}$ & 25.7 & $1.29, \mathrm{~s}$ & 27.4 & 1.07 , d. 7.2 & 27.5 \\
\hline 27 & $1.16, \mathrm{~s}$ & 25.8 & $1.16, \mathrm{~s}$ & 25.8 & $1.16, \mathrm{~s}$ & 24.6 & $1.30, \mathrm{~s}$ & 27.4 & $1.07, \mathrm{~d}, 7.2$ & 27.5 \\
\hline OH-25 & & & & & & & $4.59, \mathrm{~s}$ & & & \\
\hline
\end{tabular}


Table S2. Summary electrophysiology data of compound $\mathbf{6}$ on selected human $\mathrm{GABA}_{\mathrm{A}} \mathrm{R}$ subtypes.

\begin{tabular}{|c|c|c|c|c|c|c|c|c|c|c|c|c|c|c|c|c|c|c|}
\hline \multirow{2}{*}{$\mathrm{C}$} & \multicolumn{3}{|c|}{$\alpha 1 \beta 1 \gamma 2$} & \multicolumn{3}{|c|}{$\alpha 1 \beta 3 \gamma 2$} & \multicolumn{3}{|c|}{$\alpha 2 \beta 3 \gamma 2$} & \multicolumn{3}{|c|}{$\alpha 3 \beta 3 \gamma 2$} & \multicolumn{3}{|c|}{$\alpha 4 \beta 3 \gamma 2$} & \multicolumn{3}{|c|}{$\alpha 5 \beta 3 \gamma 2$} \\
\hline & Mean & SEM & $\mathrm{N}$ & Mean & SEM & $\mathrm{N}$ & Mean & SEM & $\mathrm{N}$ & Mean & SEM & $\mathrm{N}$ & Mean & SEM & $\mathrm{N}$ & Mean & SEM & $\mathrm{N}$ \\
\hline $50 \mathrm{nM}$ & 0 & 0.018 & 5 & -0.069 & 0.035 & 4 & 0.055 & 0.037 & 8 & -0.119 & 0.027 & 7 & -0.03 & 0.03 & 13 & -0.028 & 0.017 & 8 \\
\hline $100 \mathrm{nM}$ & -0.057 & 0.064 & 6 & 0.021 & 0.012 & 8 & -0.029 & 0.025 & 8 & -0.109 & 0.029 & 7 & -0.08 & 0.09 & 10 & 0.114 & 0.054 & 5 \\
\hline $500 \mathrm{nM}$ & -0.218 & 0.032 & 5 & -0.005 & 0.03 & 8 & -0.039 & 0.031 & 7 & -0.232 & 0.04 & 6 & -0.15 & 0.07 & 10 & -0.068 & 0.017 & 8 \\
\hline $1 \mu \mathrm{M}$ & -0.304 & 0.042 & 6 & -0.081 & 0.019 & 6 & -0.07 & 0.022 & 8 & -0.32 & 0.041 & 8 & -0.37 & 0.04 & 11 & -0.081 & 0.034 & 7 \\
\hline $10 \mu \mathrm{M}$ & -0.666 & 0.016 & 6 & -0.235 & 0.017 & 2 & -0.244 & 0.044 & 7 & -0.483 & 0.03 & 7 & -0.65 & 0.09 & 11 & -0.258 & 0.048 & 8 \\
\hline $50 \mu \mathrm{M}$ & -0.751 & 0.004 & 2 & -0.429 & 0.024 & 3 & -0.431 & 0.034 & 7 & -0.648 & 0.015 & 7 & -0.72 & 0.05 & 12 & -0.488 & 0.043 & 8 \\
\hline
\end{tabular}

